\title{
Teaching practices of adjunct and full -time faculty by inventories of good practice
}

Joyce Ricker Kronberg

West Virginia University

Follow this and additional works at: https://researchrepository.wvu.edu/etd

\section{Recommended Citation}

Kronberg, Joyce Ricker, "Teaching practices of adjunct and full -time faculty by inventories of good practice" (2004). Graduate Theses, Dissertations, and Problem Reports. 2564.

https://researchrepository.wvu.edu/etd/2564

This Dissertation is protected by copyright and/or related rights. It has been brought to you by the The Research Repository @ WVU with permission from the rights-holder(s). You are free to use this Dissertation in any way that is permitted by the copyright and related rights legislation that applies to your use. For other uses you must obtain permission from the rights-holder(s) directly, unless additional rights are indicated by a Creative Commons license in the record and/ or on the work itself. This Dissertation has been accepted for inclusion in WVU Graduate Theses, Dissertations, and Problem Reports collection by an authorized administrator of The Research Repository @ WVU.

For more information, please contact researchrepository@mail.wvu.edu. 


\title{
Teaching Practices of Adjunct and Full-time Faculty by Inventories of Good Practice
}

\author{
Joyce Ricker Kronberg
}

Dissertation submitted to the College of Human Resources and Education

\author{
at West Virginia University \\ in partial fulfillment of the requirements \\ for the degree of \\ Doctor of Education \\ In \\ Advanced Educational Studies \\ Richard Hartnett, Ed.D., Chair \\ Elizabeth Jones, Ph.D. \\ Ragina Copeland, Ed.D. \\ Edward Keller, Ph.D. \\ Scott Kelley,Ph.D. \\ Department of Advanced Educational Studies \\ Morgantown, West Virginia, \\ 2004
}

Keywords: Adjunct Faculty, Quality of Teaching, Good Practices

Copyright 2004 Joyce Ricker Kronberg 


\section{Abstract \\ TEACHING PRACTICES OF ADJUNCT AND FULL-TIME FACULTY BY INVENTORIES OF GOOD PRACTICE}

\section{Joyce Ricker Kronberg}

Institutions of higher education are under increasing pressure to manage with less financial support from the state legislatures. In order to reduce costs and provide greater flexibility, many colleges and universities are turning to adjunct faculty for a greater portion of their teaching in the classroom. However, few studies have measured the quality of instruction displayed by adjunct faculty.

The objective of this study is to assess the frequency of practice for several aspects related to teaching quality between full-time and part-time faculty. Three community colleges participated in the faculty survey: Seven Principles For Good Practice In Undergraduate Education.

In addition, the survey included a profile of the faculty and an overview of assistance provided by the colleges for their faculty members. From this portion of the research instrument, a secondary objective relative to support services, training sessions, and policies needed for better utilization of all faculty could be determined.

The study included statistical analyses of means for the frequencies of practice between the two categories of faculty. The study also examined the means to ascertain differences in practices by sex of faculty and by experience level of the faculty and also by department or academic area. Overall results showed that full-time faculty consistently showed greater utilization for all seven of the "good practices". Females showed greater usage of the good practices in all seven categories, while more experienced faculty showed more frequency of use for some, but not all, of the good practices. Two departments, education and allied health, showed greater utilization of the seven practices with allied health faculty showing best usage in four practices and the education department showing best usage in three of the practices. Overall, mathematics and science faculty showed the lowest frequency of use for the seven good practices. Social sciences, humanities, business, and technology departments were in the middle range for use of the good practices. 
The secondary objective does not show results with statistical significance. This portion of the study elucidated some concerns and problems which are common for adjunct faculty members and suggested some procedures which college administrators could employ to assist all faculty and improve performance in the classroom. The two most mentioned concerns for all faculty involve the academic level or skill level of students and the heavy commitment of time required for teaching in community colleges. 


\section{ACKNOWLEDGEMENT}

Working on a doctorate while teaching one of the heaviest loads at our college has proven to be most difficult and time-consuming. However, a number of individuals have helped me, and I appreciate their aid. First, my committee members have assisted in a number of ways. Dr. Richard Hartnett, my chair, and Dr. Elizabeth Jones, most generous with her time, assisted me with the formatting and reporting of the study. Dr. Ragina Copeland kept reminding me that the goal was possible even with all my other teaching responsibilities.

I also appreciate the help from others such as family and friends. My husband and sons, Jon and Eric, never wavered in their support. I must also thank my friend, Marshall Griffin, who encouraged, listened to me, and always did his share of the driving. Individuals from other colleges also helped; executive secretaries have my undying respect and admiration for assisting me whenever I called and asked for advice on how to procure more data and how to understand some of the information.

Lastly, I wish to thank my parents, Helen and Walter Ricker, who always guided me into reading and study and left me with an appreciation and respect for education and for doing things in a slightly different manner. I wish my mother were alive to be a part of my accomplishment, for she especially taught me to keep working for my goals.

These have been hard years with work and family and volunteer obligations, but the goal is worthwhile. 


\section{Contents}

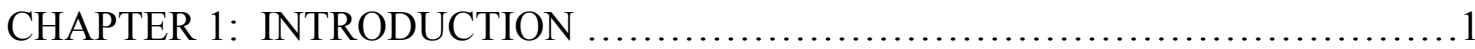

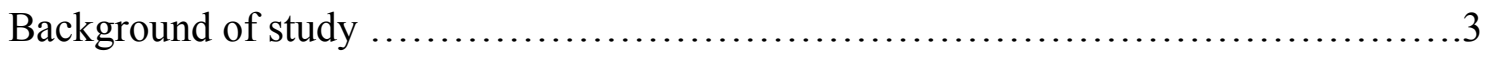

Statement of the problem..................................................... 7

Purpose of the study .................................................... 10

Justification/Need for the study ........................................ 11

Limitations of the study ................................................. 16

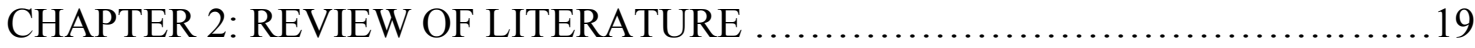

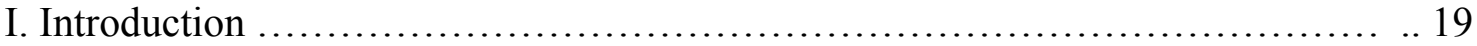

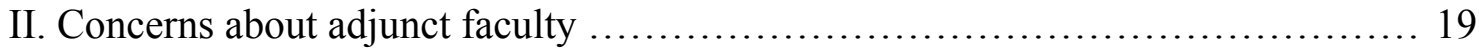

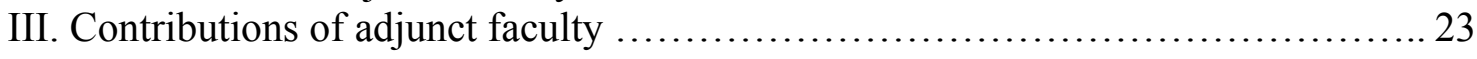

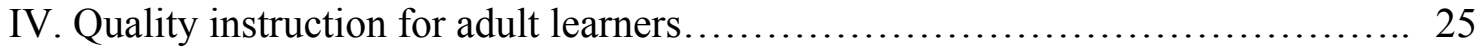

V. Needs of part-time faculty. ............................................... 26

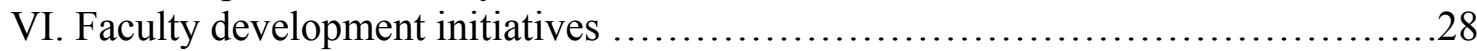

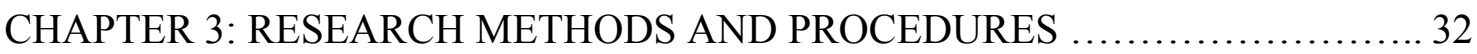

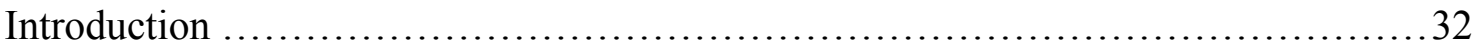

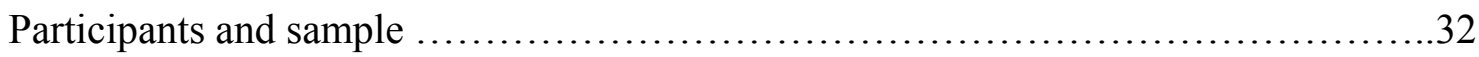

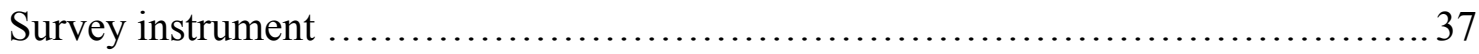

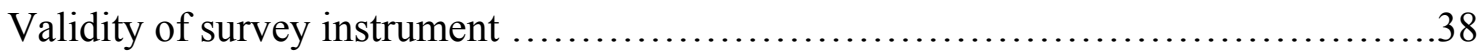

Data analysis.......................................................... 39

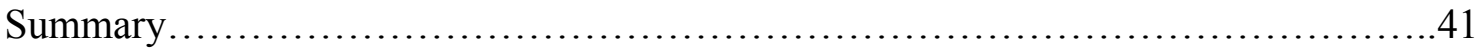

CHAPTER 4: PRESENTATION AND ANALYSIS OF DATA.....................42

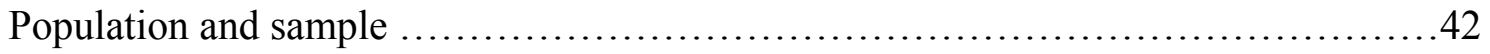

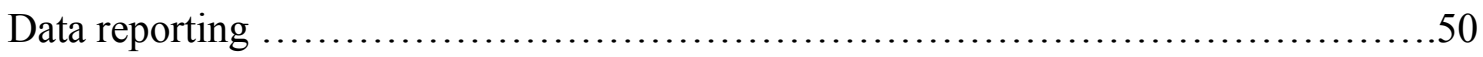

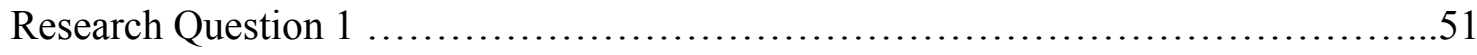

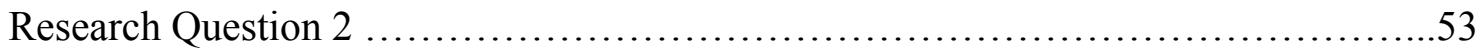




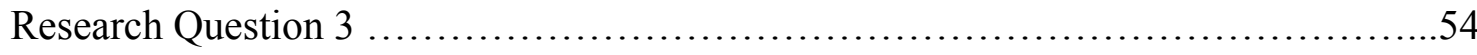

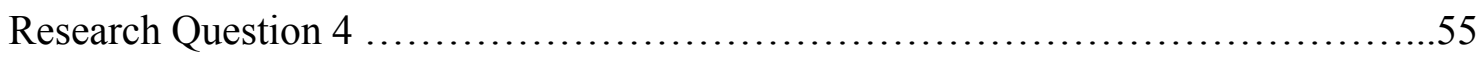

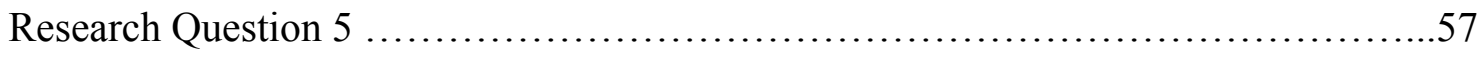

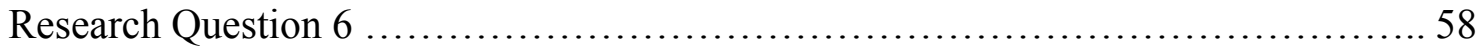

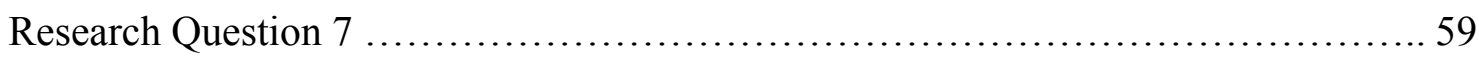

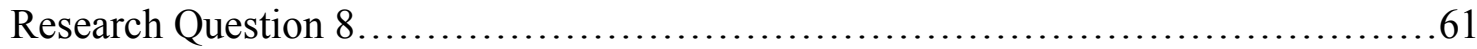

a. Differences by sex of instructor.........................................61

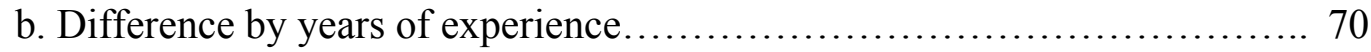

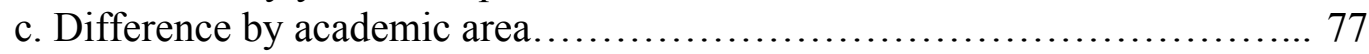

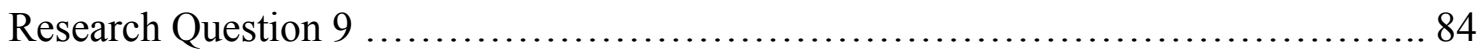

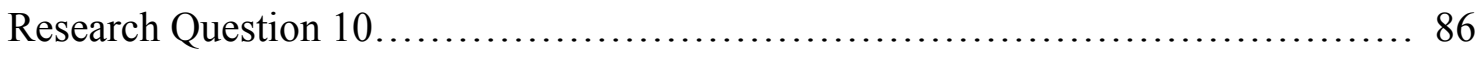

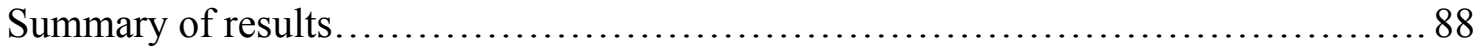

CHAPTER 5: CONCLUSIONS AND RECOMMENDATIONS ...................93

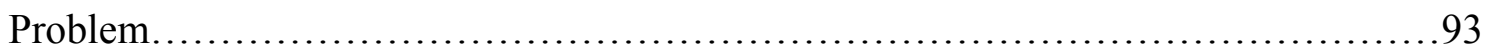

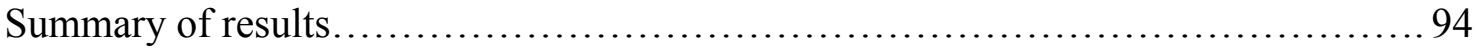

Recommendations for administrators....................................... 102

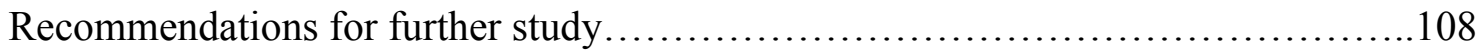

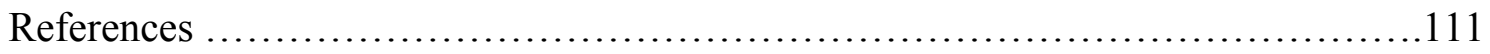

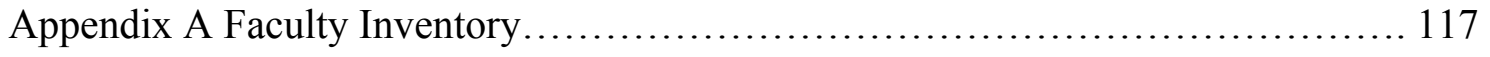

Appendix B Faculty Profile ............................................. 121

Table 1. Population of faculty members by academic area..........................34

Table 2. Response frequencies by department areas..............................35

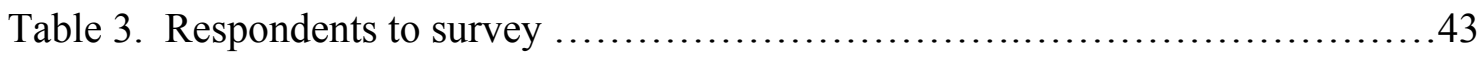

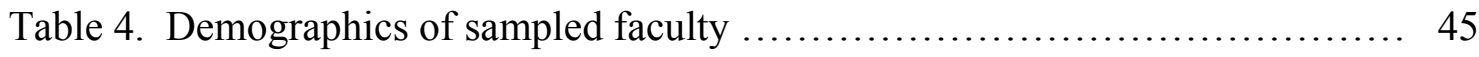

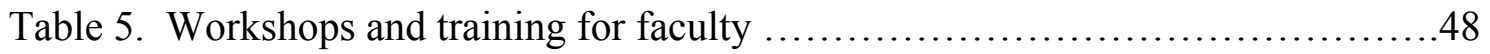


Table 6. Support services for faculty .50

Table 7. Encourages student-faculty contact by full-time and part-time faculty .52

Table 8. Encourages cooperation among students by full-time and part-time faculty... 54

Table 9 Encourages active learning by full-time and part-time faculty $\ldots \ldots \ldots \ldots \ldots . . .55$

Table 10. Encourages prompt feedback by full-time and part-time faculty .............56

Table 11. Encourages time on task by full-time and part-time faculty $\ldots \ldots \ldots \ldots \ldots \ldots . \ldots 58$

Table 12. Encourages high expectations by full-time and part-time faculty ............59

Table 13. Respects diverse talents and ways of learning by full-time and part-time faculty

Table 14. Encourages student-faculty contact by gender of faculty member

Table 15. Encourages cooperation among students by gender of faculty member........64

Table 16. Encourages active learning by gender of faculty member.................65

Table 17. Encourages prompt feedback by gender of faculty member................66

Table 18. Encourages time on task by gender of faculty member $\ldots \ldots \ldots \ldots \ldots \ldots \ldots \ldots 67$

Table 19. Encourages high expectations by gender of faculty member .................68

Table 20. Respects diverse talents and ways of learning by gender of faculty member ..70

Table 21 . Encourages student-faculty contact by years of experience of faculty ........72

Table 22. Encourages active learning by years of experience of faculty................74

Table 23. Encourages high expectations by years of experience of faculty $\ldots \ldots \ldots \ldots . . . .75$

Table 24. Respects diverse talents and ways of learning by experience of faculty.......76

Table 25. Best use of practice one by academic department..........................77

Table 26. Best use of practice two by academic department........................78

Table 27. Best use of practice three by academic department....................... 79

Table 28. Best use of practice four by academic department.........................80 
Table 29. Best use of practice five by academic department....................... 81

Table 30. Best use of practice six by academic department.........................82

Table 31. Best use of practice seven by academic department.....................83

Table 32. Positive comments for teaching at community colleges...................86

Table 33. Major concerns from full-time faculty................................ 87

Table 34 Major concerns from part-time faculty $\ldots \ldots \ldots \ldots \ldots \ldots \ldots \ldots \ldots \ldots \ldots \ldots \ldots . . . \ldots 8$

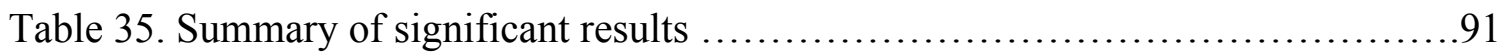




\section{CHAPTER 1: INTRODUCTION}

Employment transitions, both in settings and in staffing arrangements, are occurring in American society, both in the workplace and in our institutions of higher education. Leslie (1998) states that employment in academics is changing from a tenured faculty to one mostly employed off the tenure track. He suggests several factors as being the cause. These are "supply-and-demand imbalances in the academic work force, developing patterns of work and employment that are unique to individual academic disciplines, changes in the economic foundations and organization of American colleges and universities, and large underlying shifts in patterns of work in American society" (Leslie, 1998, p.1).

Shifts in employment duration are also occurring in the workforce; workers today must upgrade skills often, change their company or career objectives, and repeatedly develop expertise in new technologies. Since developing technologies and globalization are imposing many of these changes, this dictates that more employees need to be involved in lifelong learning to compete successfully. "Both business and higher education will be challenged to stay abreast of these changes" (Oblinger and Verville, 1998, p.ix). These authors also state that "colleges and universities must accelerate the pace of curricula restructuring to expand the flexible interface modes of teaching and learning that are sought by the workforce" (p. vi).

In addition, the typical operations of colleges/universities have changed. Stagnant numbers of traditional, college-age students, burgeoning enrollments of older students, financial restraints, an oversupply of Ph.D. holders in certain disciplines, and newer methods of educational delivery mean that colleges are undergoing shifts in the way work 
is done and in the way programs are delivered (Leslie, et al, 1982; Leslie, 1998; Magner, 1999). Within the academy, tenured professors represent a long-term fixed expense, which must be met with long-term stable resources. However, state-supported educational institutions are finding that many state legislatures are unwilling to support increasing long-term debt. In a time of "level or declining state support, a public institution's ability to attract funds from other sources is becoming increasingly essential" (Reichard, 1998, p.43). Colleges, like many other institutions, are under increasing stress to cut costs and increase flexibility. Some colleges find that increased part-time faculty use is necessary. Hiring part-time faculty was once considered to be non-traditional, but now such contractual arrangements are very common, especially in community colleges.

Relative to the use of non-tenure-track faculty, "empirical evidence on the longterm organizational consequences of such use is suprisingly sparse" (Leslie, 1998, p.78). Leslie states that "there is clearly an important need for more systematic research ... on non-tenure-track faculty" (p. 79). In addition, a recent national study on part-time faculty also notes that most recent articles and reports about effectiveness of the adjunct faculty show some "highly subjective ... arguments" (Gappa and Leslie 1993, p. 4). For these reasons, studies focusing on part-time faculty issues, such as frequency of good teaching practices, are especially needed.

"The most important academic concern is the perception that part-time faculty threaten the quality of academic programs in terms of course content, advising, facultystudent interactions, and collegiality within academic departments " (Leslie, 1998, p. 85). He also states that the quality issues have little to do with instruction and more to do with the support for learning, or providing the time and place for helping students learn. 
Within the literature, a number of articles note the excellent abilities, dedication and motivation of part-time faculty who bring cutting-edge practices into the classroom (Gappa and Leslie, 1993; McGuire, 1993). However, other authors lament lower credentials and standards, inexperience in teaching, a negative effect on the institution's research profile, and insufficient knowledge of pedagogy (Reichard, 1998; Foster and Foster, 1998; Banachwski, 1996). A concern of quality is one of the controversial questions relative to the use of adjunct faculty in higher education. The Sloan Foundation's report $(1998$, p.3) states that while $41.6 \%$ of all teaching faculty are now part-time, $60.2 \%$ of the community college faculty are part-time. A recent report from the National Center for Education Statistics (2000) shows that part-time faculty are now $62 \%$ of the teaching faculty in public two-year colleges. Since the community colleges use a higher percentage of part-time faculty than do the major universities and colleges, it would be useful to see how the faculty of one state in Appalachia view their own teaching relative to good practices determined to measure the "quality" issue. Likewise, both the fulltime and the adjunct faculty themselves should be able to offer the institutions suggestions about necessary assistance in providing a quality learning environment for their students.

\section{Background}

This study focused upon a large sample of responses to see if there were any significant differences in the quality of instruction provided by adjuncts and full-time faculty. The faculty were surveyed about their practices within the classroom and the frequency of certain techniques which they used with their students. The faculty at three community colleges in one state $\{$ Community College Mid-Central (CCMC), Community 
College-North Region (CCNR) and Community College-South Region (CCSR)\} were surveyed about frequency of good practice in undergraduate education. This study measured the quality of instruction by using the Faculty Survey: Seven Principles for Good Practice in Undergraduate Education (See Appendix A), originally developed by authors Chickering, Gamson, and Barsi in 1987. The various departments of the three community colleges may gain insights about how frequently each of the seven principles are used. Since the surveys have some open- ended questions where additional comments may be added, both adjunct and full-time faculty members may point out classroom practices and course objectives as well as needs and concerns which they deem necessary for successful instruction.

Likewise, some colleges or departments may already have faculty development programs which assist instructors to become more effective in the classroom. Administrators may provide faculty with computer access, office space, development programs, and mentoring. The faculty profile page at the end of the survey covered faculty demographics and showed what colleges offer to their faculty (see Appendix B).

This study examined several aspects relative to quality of instruction. The survey included a number of items related to teaching quality (such as active learning, objectives or expectations, professor availability, use of alternative teaching methods, promptness of feedback, professor's emphasis of time on task, and professor's procedures). Faculty rated themselves on these areas. From the comparisons between adjunct and full-time faculty, it was possible to determine those faculty and those departments showing instructional excellence. Also, the major strengths and weaknesses within colleges should become visible. From these, policy implications for helping all faculty improve 
become evident. Those faculty and departments, which consistently score high in instructional quality, should have some helpful ideas about the means by which their department inculcates effectiveness and quality of instruction. Those highly rated departments, shown by their means on the survey, could assist the colleges with helpful ideas. These teaching strategies could be made available to assist other departments participating in the study. Some of these may be physical in nature, such as telephone or computer access and training, office space, secretarial help, or special training sessions. Others may be departmental procedures, such as presenting certain workshops and programs for mentoring.

According to administrators in charge of faculty at these three community colleges, there were few developmental programs and workshops for adjunct faculty, little consistent evaluation, and almost no formal support of part-time faculty. The individual colleges used different evaluation forms, and the three colleges each provided an informational meeting each semester. However, attendance was not required and usually involved no workshops or instructional programs. The personnel in charge of part-time faculty reported a lack of office space, telephones, and secretarial help for some part-time faculty. If part-time faculty needed help in providing an effective learning environment, this study demonstrated those areas and suggested some policy changes. In addition, if any successful workshops were developed, the faculty members might be able to suggest which ideas helped them the most.

In this study, faculty from the three existing comprehensive community colleges in one state in Appalachia participated. The fourth community college of that state is not 
included in this study because it has been recently established into the community college system and also because it has no long-term history of employment for adjunct faculty.

David Leslie (1998) in his report on the growing use of part-time faculty suggests two research issues to explore. First, Leslie states that while National Center for Education Statistics (NCES) surveys provide data, a principal need is for "a more continuous way to monitor trends in faculty work" and "to find the appropriate level of disaggregation" (p. 96), since issues of part-time faculty are specific to individual disciplines and to different types of institutions. While this study did not evaluate teaching on a national level, it should show some trends in one state's community college faculty. This study can show trends within certain departments and by teaching areas.

Leslie's second direction for research involves the distinction by institutional type. Because teaching is the prime focus for community college faculty, "this context for faculty work, jobs, and careers is far different here than in research universities" (Leslie, 1998, p.96). He also states that while NCES may provide large amounts of data, "field-based qualitative studies may be even more fruitful in yielding up more textured and grounded understandings about who faculty are ... and how their work lives are connected to and play out in varied institutional and disciplinary contexts" (p. 97). This study should monitor faculty trends in one state by departments in community colleges as the institutional type.

Relative to institutional practices, Gappa and Leslie (1993, p.xvii) point out three areas that help ensure quality in delivering education. These areas note: (1) achieving educational objectives and better use of part-time faculty, (2) being fair in employment practices, and (3) investing in human resources and better integration of part-time faculty. 
The faculty surveys could provide information on educational objectives and best practices in undergraduate education and investing in human resources of faculty. This study did not seek to determine fairness in employment, but that issue might become evident in the qualitative portion of the survey.

"The solid foundation required for a learning college is greatly strengthened by an emerging body of research on learning. Learners learn best by doing, by working on real problems in real environments; ... there are significant differences in learning styles of individuals; and the natural functioning of the brain provides the best road map for the learning enterprise" (O'Banion, 1997, p. 81). This educational research on learning provides the basis of the "Seven Principles for Good Practice in Undergraduate Education.” The faculty survey investigates a faculty member's use of the seven principles. Although both student and institutional surveys have been adapted from the faculty survey, this research project focused strictly on faculty practices related to the seven principles.

Balch (1999) states, "Our strategic plans and implementation procedures must include the definition of the role of part-time faculty and the means to support them. They are here to stay" (p.40). This study should provide data for several areas: ways to plan for better use of adjunct faculty, methods to orient the part-time faculty in finding areas of support and increased participation, and workshops to promote better effectiveness of all departmental employees.

\section{Statement of the Problem}

By the early 1980 's, nationwide, one in every three faculty members was labeled as part-time (Gappa, 1984). Indeed at the community colleges, the part-timers were used 
more heavily still; the American Association of Community and Junior Colleges reported 55.8 percent of faculty as part-time in the fall of 1976 (Leslie, et al. 1982, p.19). In the Tuckman (1978) study, 36 percent of faculty were part-time faculty in four-year colleges and 26 percent in universities. By the 1997 report from the National Center for Educational Statistics, results indicated that the number of part-time professors had increased over a 25-year period to more than 42 percent (of all faculty in all types of higher educational institutions) at the time of the survey. In addition, in the recent Sloan Conference on part-time and adjunct faculty (1998, p.3), reported "over $60 \%$ of faculty teaching courses at community colleges" are part-time. Recent nationwide statistics continued to show an increase in adjunct faculty in all colleges and universities; however, "of the community college faculty members, 65 percent serve part-time" (American Association of Community Colleges, 1995-1996, p. 8).

Clearly, then, the current trend in American higher education is toward increased hiring of part-time or adjunct faculty members. The role played by these part-time instructors relative to the academy, quality of academic programs, operation of the institution, effect on policy, relationship to the students, and interaction with the outside community can only be expected to expand in the coming years. The effect this expanding group will have on American institutions of higher education needs to be studied. Yet, very few studies have focused on these individuals as a study group.

As noted earlier in this Chapter, voluminous texts and numerous articles decry the effect of part-time faculty on higher education. However, necessity continues to drive the hiring practices, but few studies have focused directly on adjunct faculty. It seems that many colleges and universities are content to "pay them poorly, use them as needed with 
little concern for their long-term welfare, and keep them outside traditional academic governance” (Gappa, 1984, p.7). In addition, "full-time professors have done little besides watch and wring their hands" (Leatherman, 1997, A14). However, many fulltime faculty also realize that the increased demand for adjuncts is coming directly from them as they request more part-time help for their programs. In actuality, full-time faculty often see the ascendance of adjunct faculty as a threat to their financial well-being and criticize that "the excessive use of part-timers erodes educational quality and threatens tenure" (Mangan, 1991, p. A9). In addition, many full-time faculty members note that the use of non-tenure-track instructors "diminishes the professional status of all faculty members" while others "charge that universities pursue research at the expense of teaching” (American Association of University Professors \{AAUP\}, 1992, p. 39).

Since data from part-time faculty are meager and the use of part-time faculty is not expected to decrease soon, studies focusing upon these faculty can only expand the knowledge available to colleges. "In contrast to other institutions of higher education, the community college has always taken great pride in its commitment to teaching as its highest value" (O’Banion, 1997, p.27). A study about quality of education in the community college by the part-time faculty could be illuminating. This study will investigate factors relative to high quality of instruction, which researchers and educators identify as strongest in terms of student success and student satisfaction. The adjunct faculty can point out areas where they could use assistance to create a better environment for their students' successes.

Much of the increased enrollment in community colleges is due to adult learners returning to develop new workforce skills. Community colleges are at the forefront 
because they offer programs that place high quality graduates in sought-after professions and "in 1992, 96 percent of community colleges provided workforce training programs for business and industry employers in their communities" (American Association of Community Colleges, 1995-1996, p. 7). Therefore any effective community college instructor needs to understand more characteristics of adult learners and be able to motivate and relate to them. Adjunct faculty will see even more adult learners, due to their night course offerings.

\section{Purpose of the study}

The overall objective of this study was to investigate relative effectiveness of adjunct versus full-time faculty in three community colleges as measured by seven indexes of good teaching practice. This investigation measured the seven characteristics, which researchers identified as being strongest in terms of student learning and outcomes. Specifically, the following questions were answered:

1. Are there significant differences in how full-time faculty encourage student-faculty contact versus how part-time faculty encourage such contact?

2. Are there significant differences in how full-time faculty encourage cooperation among students versus how part-time faculty encourage such cooperation?

3. Are there significant differences in how full-time faculty encourage active learning versus how part-time faculty encourage active learning?

4. Are there significant differences in how full-time faculty give prompt feedback versus how part-time faculty give prompt feedback?

5. Are there significant differences in how full-time faculty emphasize time on task versus how part-time faculty emphasize time on task? 
6. Are there significant differences in how full-time faculty communicate high expectations to students versus how part-time faculty communicate high expectations to students?

7. Are there significant differences in how full-time faculty respect diverse talents and different ways of learning versus how part-time faculty respect diverse talents and different ways of learning?

8. Are there significant differences in good teaching practices based on demographic characteristics of the faculty (for example, by sex or by years of experience or discipline)?

9. Qualitatively, what developmental interventions (in-service workshops) and administrative policies do colleges use to enhance quality for their adjunct faculty?

10. What positive features and strategies (to address teaching challenges) should be added in support of their adjunct and full-time faculty (to improve the quality of instruction)?

\section{Justification/Need for the Study}

Definition of terms

A. Full-time faculty -These individuals are hired on a full-time contract. "On average, the full-time instructional faculty or staff member at public community colleges worked just under 47 hours per week; taught 4.5 credit classes for a total of 13 classroom credit hours; spent 17 hours per week teaching credit classes; and instructed a total of 103 students in credit classes" (National Center for Education Statistics, 2000). 
B. Adjunct or part-time faculty-The term part-time faculty will refer to an individual who teaches courses and is employed on some basis other than a full-time contract. They may also be referred to as adjunct faculty. The employment may be long-term but still part-time. This group includes temporary hires, substitutes, fill-ins, or on-call instructors for specific classes. Teaching assistants are not included, and neither are faculty who teach full-time but are not considered for tenure (Leslie, 1998, p.1).

C. Teaching effectiveness-The American Association of Higher Education and the Education Commission of the States convened educators to review the literature on college learning and reduce it to guiding principles. The group proposed the "Seven Principles for Good Practice in Undergraduate Education" (Chickering, Gamson, and Barsi, 1987).

1. Encourages student-faculty contact

2. Encourages cooperation among students

3. Encourages active learning

4. Gives prompt feedback

5. Emphasizes time on task

6. Communicates high expectations

7. Respects diverse talents and ways of learning

A recent trend in American higher education is toward "a substantial increase" in the use of part-time or adjunct faculty (NCES, 1997, p.v). The role which these individuals play relative to the academy, the quality of academics, policy effects, and student and community interactions can only be expected to increase in the coming years. The effect of this group on quality of education should be explored because few studies center on adjunct faculty as a study group. Few studies of part-time faculty are fieldbased studies, and few involve the adjunct faculty members themselves as the participants. 
While there are some concerns about the increasing reliance on part-time instructors, many full-time faculty need to recognize that the "requests for adjuncts are coming from faculty, not the administration" (Leatherman, 1997, p. A14). Much of the literature about adjuncts seems to question the quality of their work. Descriptions in the literature seem to suggest a faculty not available to help students. These descriptions include "faceless departments," "a systematic problem," "the invisible faculty," "national trends that together threaten to kill higher education," and "destroying public confidence in education" (Leatherman, 1997, p. A12; Gappa and Leslie, 1993; Farrell, 1992, p. 30; and Thompson, 1992, p. 25). All of these definitions about part-time faculty indicate a need for more study of part-time faculty.

In addition, a number of articles also stress the contributions of adjunct faculty. Gappa and Leslie (1993, p. xii) laude adjunct faculty "whom we know to be capable, dedicated, and productive people." The two authors also note that institutions "gained a great deal when they employed practicing professionals, retired teachers, artists and musicians, and aspiring academics with advanced degrees as part-time faculty members." Likewise, some administrators (McGuire, 1993, p.1) maintain that these faculty members can be "good and highly motivated teachers, receiving the same ratings and achieving the same student outcomes as their full-time counterparts."

In The Invisible Faulty, Gappa and Leslie (1993) stated part-time faculty members have been widely alleged to have a negative impact on "quality." The authors (p. 4) note that "several key policy statements during the 1980's did address the use of part-time faculty" ... "and made bluntly negative assumptions about the impact part-timers have had (or will have) on quality." However, very little hard evidence was presented, and 
most of the allegations did not correspond with the authors' previous findings. They stated, "From our earlier work on part-time faculty, we have reached conclusions at some variance with the prevailing assumptions" (p. 5). In fact, the two authors reported that "we also found that part-time faculty are, for the most part, superbly qualified for their teaching assignments, highly committed, and conscientious about doing their jobs" (p. 6). For that reason the two authors decided to undertake their 1993 national study.

Gappa and Leslie interviewed the chief academic officer, deans, department chairs, and part-time faculty at eighteen colleges, including five community colleges. They did employment profiles on the part-timers but did not study their quality of instruction. For the chief academic officer, policies relating to part-time selection, evaluation method, and supervision were investigated. For the chairs, questions addressed hiring, monitoring and evaluation, support and development of part-time faculty. One question focused on quality and asked about the evidence of teaching by comparing full-time to part-time faculty, but the topic was mentioned only in passing.

In their conclusions, these authors noted that, "Part-timers do a significant amount of the teaching at most institutions. Yet they are most often treated as consumables than as capital investments" (p. 276). They suggested that these employees, if developed and appreciated, could give a better return on the institution's investment. For that reason, they presented a number of recommendations to improve selection, orientation, professional development, mentoring programs, assessment, and incentives to motivate part-time faculty.

In the Gappa and Leslie study, one question did get at the adjunct's perception about the relationship to the full-time faculty. The researchers asked, "How satisfied are 
you with your current work and with your department (status, support, relationship to other part-timers and to tenured faculty)?" From their research findings, they recommended several practices, all of which encourage joint efforts to bring the part-time and full-time faculty closer together.

After all their site visits, they prepared a report of some recurrent themes. They found faculties in two castes, high-class (full-time faculty) and low-caste (part-time faculty). They concluded that the separation produced damage "to the general ethic of community that academies have long honored and is also damaging to the quality of education" (p. 12). They suggested that educational institutions need to foster a new sense of community. To these authors, it also seemed most unfair to blame any decline in the quality of post-secondary education on the victims, the part-time faculty.

The debate over quality of adjunct instruction can be expected to continue for some time. This study will focus on the perceptions which community college faculty members themselves have about their teaching practices, what they have encountered or practiced during college teaching. Higher education professionals could use the results of this study to increase the probability of hiring excellent part-time faculty. A greater understanding of personality traits, classroom behaviors, and backgrounds and experiences could benefit future employment. Department chairs or deans responsible for recruitment and hiring could benefit from the study's results.

Nationwide, it seems that a paucity of research exists with adjunct faculty as the central focus. Most research seems to focus on profiles and classifications of career types. Little work has been done on the quality of instruction by adjunct faculty. A study needs to be done in one state's community colleges to determine if adjuncts provide a 
high quality of instruction. Since $62 \%$ of instruction (at community colleges) is done by part-time faculty, this information would certainly be useful to administrators. If the part-timers are effective in instruction, then administrators could hire adjuncts with fewer reservations. If the adjuncts are not effective, then policies for changing their environment and developing their instructional skills need to be incorporated. A list of adjunct concerns and challenges could be useful as administrators seek to address some of the dealings and matters relative to part-time faculty.

\section{Limitations of the study}

The sample in this study is drawn from the faculty at three community colleges in one Appalachian state. Two of the schools are free standing community colleges, and the history at the third is that of a long-term community college, which recently merged with the state's land grant university. As such, these faculty members consider themselves to be community college instructors. However, other community colleges in the state are components of four-year colleges or universities. Frequencies of certain teaching practices for the test schools might be different from those at the other component community colleges (enclosed within a larger university). For example, community college faculty at those institutions might also teach in both baccalaureate and masters level programs, but this survey is based on practices deemed important for undergraduate education only. Consequently, observations from this study should not be transferred automatically to other faculty members, who teach in other community colleges of the state, which are part of a larger four-year college or university.

Another major difference is in hours spent by the faculty member in teaching. The "community college has always taken great pride in its commitment to teaching as its 
highest value" (O’Banion, 1997, p.27) while major universities stress research and service. Therefore those individuals most interested in teaching might tend to congregate in the community colleges, or the administration at these colleges may recruit proven teachers over researchers. Any faculty member who must contribute significant amounts of time to research and assisting graduate students may not be available for much undergraduate student-faculty contact.

From this study, several recommendations to help faculty emerge. Larger institutions, which have many more employees to integrate into the campus community or which have promoted developmental programs for a long time, may have already developed many workshops or support facilities suggested by this study. Some community colleges may have years when there are no new full-time faculty members, and no workshops are developed to assist these faculty members into the campus community. The differences in levels of resources can influence the results.

The framework of the study focuses on good practices in a college environment. Newer delivery systems, such as compressed video, Internet courses, and Web based instruction would not employ much student contact, and the students might never meet physically. So any conclusions from this study may not apply to faculty teaching alternative delivery courses.

The main limitation of this study is its focus on only three community colleges in one state, and that state is rather homogenous in its population. While results from the study may transfer easily to other small community colleges in rural states, the results may not reflect teaching practices at more urban institutions, for colleges drawing from a 
wide range of student cultures and religions, or for colleges based heavily upon technology for delivery of the coursework. 


\section{CHAPTER 2: REVIEW OF LITERATURE}

\section{Introduction}

A review of the literature relative to part-time faculty shows much confusion relative to the value and role of these faculty in higher education. Many authors express dissatisfaction with their use in colleges, while other writers are sympathetic and complimentary. In addition, there exists "a discomforting universality in the feelings of part-time faculty that somehow they are being exploited, and blatantly so" (Gappa and Leslie, 1993, p. xiii). So these faculty members themselves reflect a number of needs and concerns. In addition, there appear to be no clear-cut institutional policies toward the evaluation, monitoring, and development of part-time members of higher education. Since these faculty members often teach at night and are more likely to encounter adult students, some references relative to quality of instruction for adult learners need to be reviewed. The literature survey covers these main areas.

\section{Concerns about adjunct faculty}

Obviously there are a number of concerns toward expanding the use of adjuncts in the higher education arena. One significant area of confusion and concern is the instructional quality of college courses. In 1997, representatives of ten academic associations met as a conference on the growing use of part-time and adjunct faculty. The areas represented included most of the humanities, social sciences, mathematics and the American Association of University Professors (AAUP). The delegates agreed that, in general, part-time faculty members were less likely to hold doctorates, and they were expected to teach in substandard conditions. They were less likely to have an office and 
hold office hours. In addition, they had less printing or secretarial help, had irregular feedback and evaluation, had less access to committees or colleague interaction, showed little involvement in governance, and had less opportunity for professional conferences. Also their pay and benefits were low. This group recommended for "administrators and faculty to avoid excessive or inappropriate reliance on part-time or adjunct faculty" (Conference, 1998, p. 54).

Some full-time faculty state that part-time "lecturers are more likely to give higher grades because their positions are so dependent on good student evaluations" (Leatherman, 1997, A13) and this will lower quality of instruction. Foster and Foster (1998, p. 30) sum up several concerns succinctly with two questions: 1 . What is the effect of many part-time professors "on the quality of the education a college or university can offer?" 2. "What are the consequences for the long-term health of the institution?" Their experiences suggest the answer to both questions is "deleterious on both counts." These authors agree that the adjunct faculty cannot assume responsibility for full academic development of their students. "It is not the temporary professors who are to blame, but the terms of their employment, which weaken their ability to foster excellence and to become genuinely involved with students" (Foster and Foster, 1998, p. 32). They often cannot defend their academic standards because they are insecure, preoccupied with seeking a full-time, "real" job.

Karen Thompson (1992) pointed out another aspect of part-time faculty use. She suggested that using many part-time faculty was a way to cut off expenses and costs, but with another motive. She considered heavy use of part-timers to be "a broader business strategy to minimize pay and maximize control" (Thompson, 1992, p. 22). The use and 
abuse of part-timers could suggest that "insecurity also breeds fear of reprisal, further reducing union involvement of people" (Thompson, p. 24). All of this would lead to divided faculties, limited bargaining power, and less effective faculty governance.

Another author suggested that most of the "problems experienced by part-timers are attributed to full-time faculty more interested in protecting their professional privilege than in educational quality or employment quality" (Rhoades, 1996, p.627). This might be an addendum to the Thompson article. Perhaps the concern expressed about heavy use of part-time faculty was seen as merely a threat to the bargaining control of full-time faculty. In that case, the question of "quality" could be merely a red herring.

Some research about the quality of part-time instruction can be found in the literature. One quantitative study did focus on the quality issue between part-time and full-time faculty. Klein, et al (1996) studied eight social work programs (BSW and/or MSW programs). Each responding school received three questionnaires-one for the dean/director of the group, one for the adjunct faculty, and one for students. Altogether 6 deans, 43 adjunct faculty from 5 programs, and 175 students participated.

The respondents assessed course quality, availability of instructor, and teaching skill, using a 5-point Likert-type scale. The students rated the adjuncts less favorably than the full-time faculty in all the areas. However, for both the part-time and the full-time groups, the average values of the student assessments were positive (more positive values than negative values) for all questions. The quality of the courses taught by the full-time faculty was rated as more highly positive. There appeared a high correlation between the course quality and adjunct skill. Overall, these researchers found that "students regard adjunct faculty as somewhat less effective than full-time faculty but appreciate their 
expertise on contemporary or specialized practices" (Klein, et al., 1996, p. 253). Five community colleges were included as a part of this study but were not separated out in the resulting conclusions. The authors concluded their paper with "additional research in this area would clarify the types of institutional support that can strengthen the contributions of adjunct faculty" (Klein, p.262).

The administrators in this study did appreciate the financial benefit and flexibility offered by the adjuncts. The adjuncts themselves rated financial concerns as slightly important but rated the social/ professional connection to the educational program as very important or important. In this study, the part-time faculty members had very limited interaction with the full-time faculty. Therefore, it seemed that their connection to the program was based on some factor other than collegial relationships with the full-time faculty. The authors suggested that it could be exposure to the current literature or to teaching itself. Perhaps the relationships to the institution and to other full-time faculty might be important to other departments, but were less so to practicing social workers in the field.

Another statistical study focused exclusively on the community college and the effectiveness of its adjunct faculty. Bolge (1995) studied the amount of learning by the students relative to the status of the instructor (full-time versus part-time). He found no significant difference between the scores of students relative to the different categories of faculty. He concluded that "students taught by full-time faculty fared no better in posttest scores (final grades) than students taught by part-time faculty' (p. 3). Since his study focused only upon remedial mathematics classes, the study showed very limited application and results. His conclusions recommended "continuing the practice of 
employing part-time faculty," and he "suggested more research on part-time faculty" (p.3) since he found very little previous research on the topic.

Another area of concern was the tenuous relationship between the part-timer and the college or university. According to the AAUP Report in 1980, part-time faculty had little access to the school's governance and would feel less appreciated. The report noted that faculty members who are treated as "hired hands," with little or no input, might be "insufficiently motivated to perform with the care and ingenuity of the faculty member who is actively involved in shaping his or her environment" (AAUP, 1980, p.7).

An additional topic of concern was the relationship of the part-timer relative to other faculty members, especially those who are full-time. Lundy and Warne (1990, p. 217 ), in their interviews with part-timers, stated that $58 \%$ of part-timers were dissatisfied with their status as part-time employees. Some dissatisfied adjuncts complained about patronizing attitudes and arrogance and noted "the shameless arrogance of the aristocracy of the ancient regime, especially those who talk most loudly of their sympathy for the oppressed" ( p.216). They included one interviewed adjunct, who stated, "what bothers me most is the way most full-timers treat me and other part-timers as if we were a lower form of life." Thus some adjunct faculty would have difficulty developing a close relationship to the institution or to anyone in it. This study corresponded with the Gappa and Leslie study finding two distinct castes of faculty members.

\section{Contributions of part-time faculty}

A number of administrators, such as McGuire (1993, p.1), note that the part-time faculty members bring some needed breadth, depth, and practical considerations to the curriculum and "allow colleges to teach subjects that would otherwise be excluded from 
the curricula. They can provide a strong link to the community and to the workplace, as well as a tried and tested talent pool for recruiting full-time faculty." He further maintains that these faculty members can be "good and highly motivated teachers, receiving the same ratings and achieving the same student outcomes as their full-time counterparts." In a similar way, Cohen and Brawer (1996, p.87) state that part-time faculty "may be more directly connected to the practical aspects of their work, and they may have a greater level of knowledge than most full-time faculty.... and their students rate them as highly as they do the full-timers."

Even authors Foster and Foster, who are critical of much part-time faculty use, suggest that institutions have some good reasons to hire adjuncts. They state that, in the correct environment, adjuncts and lecturers can be of great benefit. Many such instructors are "recent graduates who bring fresh ideas, conversation, and the latest news from graduate programs to the students and established professors" (Foster and Foster, 1998, p.30). In addition, they can be "excellent teachers, combining enthusiasm and an innovative spirit with a serious scholarly outlook.” In many areas, practitioners may bring more real-world experience, along with "relevancy and excitement to the subjects being taught" (p. 31). However, this excellence is often lost because the adjunct's "struggle for survival provides strong incentive to relax standards in the hopes of getting the good teaching evaluations" which are useful for getting a better job.

In a dissertation comparing perceived teaching effectiveness of full-time faculty, graduate teaching assistants, coaches, and part-time faculty in physical education classes, part-time faculty were consistently rated the highest of the four faculty groups (Sutliff, 1992). Another interesting aspect of this study found that female students rated 
instructors higher than did male students. The time of the class also made a difference in the evaluation scores; classes after 12:00 p.m. received higher scores.

\section{Quality instruction for adult students}

Morano, in his 1983 dissertation, tested students' perceptions of adjunct faculty teaching. The results showed that certain types of students rated adjuncts significantly higher. Part-time students rated adjuncts significantly higher than did full-time students. Also students who worked full-time and older students rated part-time faculty significantly higher. Since certain students rated instructors differently, this author suggested "matching" students with instructors.

In addition, the teaching techniques, which are well received by younger students, may not be the most effective for adult learners. Brookfield's book offers a number of suggestions for working with adults returning to college. He concludes with, "Good adult teaching is generally seen as the ability to set a certain emotional climate, to use learners' experiences as educational resources, to provide plenty of evaluation information to students, and to encourage collaboration and participation" (Brookfield, 1986, p. 135).

Teaching style plays a part in student learning. "Teaching style refers to the distinct qualities displayed by a teacher that are persistent from situation to situation regardless of the content" (Conti, 1990, p. 80). Current educational practices note two learning styles: teacher-centered where learners are passive and become active by reacting to environmental stimuli and learner-centered where education focuses upon the learner rather than a body of information. "Although a teacher-centered approach is 
widely practiced in adult education, the learner-centered approach is strongly supported in the field's literature" (p. 81).

Adult learning studies suggest that adult learners value experience as a major resource in learning and tend to be life-centered in their orientation to learning. Klein's study found that students did appreciate adjunct faculty, who can "bring to the classroom expertise developed from their work-related experiences, enhancing the educational experience of students and the overall educational enterprise" (Klein, 1996, p. 254). Adult learners would seem to "match" with many part-time faculty. Indeed, that seemed the case with Klein's study. The student ratings where "all the students sampled had taken at least one adjunct-taught course were the highest; and the aggregate rating from a program whose students reported the least experience with adjuncts was among the lowest" (p. 258).

Adult educators must hold the attention of the students to motivate them.

"Research constantly shows that adults are highly pragmatic learners. They have a strong need to apply what they have learned and to be competent in that application" (Wlodkowski, 1990, p. 98-99). For workers returning to community colleges for night classes, practicing professionals who are adjunct faculty would seem to be the best "fit." However, those faculty members may certainly need help to create a good learning environment for such pragmatic students. Therefore, many part-time faculty may need some instruction or developmental programs in adult learning theories.

\section{Needs of part-time faculty}

A number of articles in the literature recommend guidelines for good practices relating to adjunct faculty members. Many of these get at the issue of "fairness." These 
include hiring based on qualifications, timely recruitment, more assurance of consideration for tenure-track jobs, more long term planning by the institution, sufficient notice for reappointment, more opportunities for development and advancement, and more integration and access to communications and governance (Conference, 1998; Committee G, 1992). Similarly, other authors recommend forming policies to provide employment of adjunct faculty based on efficiency, responsibility, quality of outcomes, more access to part-timers, and fairness (Leslie, et al., 1982).

Biles and Tuckman (1986) set forth an entire book of recommendations on most aspects of part-time employment, emphasizing due process and fairness. In the introduction, these authors state that, "To provide a clearly articulated standard of 'fairness' is a key objective of this book" (p. 5). It appears that most of their management policies are still not currently in place; perhaps the book's policies, published several years ago, were presented too soon.

One recent article provides a list of policy recommendations for administrators to employ when relating to part-time faculty. Balch (1999) suggests a number of practices for recruitment and hiring, workload expectations, governance issues, job security, integration and participation by part-timers, compensation, benefits, rewards, evaluation, and professional development. She suggests that colleges and universities must "take the time and energy to unite its cadre of full- and part-time faculty who are working together for the same common interests of student learning" (p. 39). She concludes by stating that colleges' plans and procedures must include part-time faculty, plus some means for supporting them, because they are "here to stay." It is rather interesting to note that 
these recommendations have been proposed for a number of years; the Biles and Tuckman book presents many of these.

Part-time faculty need access to professional development, as do all faculty. With tightness in finances for higher education, development monies for adjunct faculty will be limited. One Internet project illustrates how to conduct an electronic conference. "Speakers" can post papers relating to the topics being discussed at an international conference. This electronic conference costs participants nothing. For adult educators, participants may get started with the Internet Directory of Literacy and Adult Education Resources; this book gives descriptions and addresses to the best adult education sites on the Internet. "Expanding professional networks and sharing resources on the Internet allow educators to be more productive and to be a part of the leading edge of the adult education field" (Heinrich, 1996, p. 10). Increasingly all faculty may be encouraged to explore this type of personal development. However, this method of development will require focused, dedicated faculty.

\section{Faculty development initiatives}

Friedlander (1979) reported that part-timers have less access to support and institutional services. Technology such as videos, teleconferences, and instructional programming might be used to help orient, develop and give support to part-time faculty. Only a few schools in the West were beginning to use this technology to help adjunct professors. Richardson (1992) reported that some California community colleges used an Instructional Skills Workshop to help part-timers with instructional experiences. This workshop contained a 24-hour course designed for instructional improvement and based on actual teaching. Each workshop included two facilitators and five or six adjunct 
faculty members. These workshops covered specific, fundamental teaching methods, lesson planning, lesson preparation, and development of teaching aids; this workshop was considered to be phase one of the program. Video taping of mini-lessons allowed the part-time faculty member to receive feedback and to help expand teaching techniques. Much of this program used full-time faculty as facilitators with time to give feedback and hold discussions with the part-timers.

In phase two of the program, participants also got additional training for specific, teaching topics such as active learning, critical thinking methods, and more participatory and collaborative types of experiences. Since the work focused on community colleges, the methods were selected as being important for adult learners. The teaching part (with conferences and discussion) had a high amount of participant involvement.

In the final phase of the program, Teaching Analysis was done; this was included to assist the professors in exploring new techniques. This portion of the program included applications for certain techniques, with in-depth focus on one standard technique or upon a novel approach. For example, some full-time faculty presented an analysis of their testing procedures. Part-time faculty who completed the entire program were called Associate Adjuncts; all such adjuncts received pay at a permanently higher rate than did other part-time instructors. The college found the entire Associate Program to cost $\$ 4000-\$ 5000$ per year. Most of the cost was for full-time faculty to conduct the workshops, and there was a small stipend to the participants. Participants rated the Instructional Skills Workshop as "overwhelmingly positive," and they also enjoyed the participant involvement and the "practice teaching" (p. 32). Full-time faculty acted as 
facilitators throughout this program; therefore, closer relationships developed between the two faculty groups.

One recommendation from the program was to, "Bring adjunct instructors into the planning and execution of the program as early as possible" (Richardson, 1992, p. 33). Another recommendation involved finances; it stated that "faculty development for adjunct faculty will not succeed unless sufficient incentives, particularly money and status are provided" (p. 33). Overall this Associate Program served two purposes: provision of new teaching experiences for adjuncts and promotion of a climate for growth and collegiality.

The program described above is designed as a low-cost way to help adjuncts adjust and become better instructors. The program is also used to ease the estrangement and sense of isolation felt by some part-timers. In addition, the completion of the Associate Program will bring financial rewards to the participants who complete the entire program. In this way, a few community colleges are beginning to invest in the future of the part-time faculty, and this faculty development should reap rewards, such as improvements in teaching, more commitment to the institution and more contact and interaction with the full-time faculty.

Newer studies show the use of technology as being a way to contribute to adjunct faculty morale and commitment. Digranes and Digranes (1995) review several current technologies used to help train part-time faculty in United States community colleges. Some methods address the lack of training and integration into the college; current uses involve print and visual media for training faculty in teaching techniques and as orientation to the college. Others address the area of training and experience in 
education, particularly in the area of adult education. Videos, for training and mentoring, allow a review of teaching performances. Some of the methods used in the community colleges also allow a great deal of interaction between the full-time and part-time faculty, especially if full-time faculty are involved as facilitators. Teleconferences on both teaching methods and available use of new technologies may be used in professional development. Interactive technologies, using video and computer software, also provide professional development possibilities. "Expanding the use of current technologies to orient, train, and support part-time faculty is emphasized" (Digranes and Digranes, 1995, p. 161). However, very few articles in the literature involve asking adjuncts what assistance they may suggest for functioning in the current scheme of higher education. 


\section{CHAPTER 3: RESEARCH METHODS AND PROCEDURES}

\section{Introduction}

This chapter reviews the methods used in carrying out the study, the selection of the population, the sample size, the instruments used to collect the data, and data analysis. The statistical t-test is used "to determine significant differences between two samples means" (Issac and Micheal, 1998, p.183). The two samples are adjunct faculty and fulltime faculty.

The research embodies both qualitative and quantitative perspectives. Because the faculty surveys require numerical evaluations, these results will be mostly quantitative and can be compared using the t-test. However, the open-ended questions on the faculty survey and on the faculty profile yield qualitative information. The faculty profile sheet asks for both positive and challenging aspects of community college teaching.

\section{Participants and Sample}

The population for the study consisted of all adjunct and full-time faculty from three public long-term community colleges in one state. The participating institutions for the study are labeled Community College Mid-Central, Community College-North Region, and Community College-South Region. Even though Community College MidCentral is now a regional campus of the state's land grant university, its overall mission and its history is that of a community college. Each community college provided a list of 
faculty names to the researcher. See Table 1 for faculty numbers arranged within their academic areas. All numbers are from Spring 2002 college data.

Since these three colleges used different terms for academic affiliations, and some had collections of areas under distinct chairpersons or deans, I surveyed based on subject area. If some departments did not use adjuncts or used adjunct faculty only in certain semesters, then only full-time faculty were surveyed for the studied semester. To achieve a suitable sample size, I tried to achieve at least $50 \%$ return of both groups. Two followup letters were used to procure the required numbers.

Table 1 shows that the highest numbers of faculty hired at these colleges are in the support areas, such as social sciences and humanities. Technology, including computer science, and the math/science areas also have high numbers of faculty since many of their courses are required in a number of the career programs or degrees, plus are requirements for students transferring on to other four-year colleges or universities.

The first three academic areas listed in the table are career programs. All three community colleges have a number of degrees in the allied health area and they all offer some terminal business degrees (either associate or bachelor). High numbers for faculty in those areas are seen. However, only one college offers a bachelor's degree in education and another college offers a very limited certificate in early childhood education. Community College-North Region does not hire anyone in the education area. For these reasons, the numbers of faculty seen in the education area are low. 
Table 1

Population of Faculty Members by Academic Area

\begin{tabular}{|c|c|c|c|c|c|c|c|}
\hline \multirow[t]{2}{*}{ Department } & \multicolumn{3}{|c|}{ Full-time Faculty } & \multicolumn{3}{|c|}{ Part-time Faculty } & \multirow{2}{*}{$\begin{array}{l}\text { Dept. } \\
\text { Totals }\end{array}$} \\
\hline & $\begin{array}{l}\text { CC-Mid } \\
\text { Central }\end{array}$ & $\begin{array}{l}\text { CC- } \\
\text { North } \\
\text { Region }\end{array}$ & $\begin{array}{l}\text { CC- } \\
\text { South } \\
\text { Region }\end{array}$ & $\begin{array}{l}\text { CC-Mid } \\
\text { Central }\end{array}$ & $\begin{array}{l}\text { CC- } \\
\text { North } \\
\text { Region }\end{array}$ & $\begin{array}{l}\text { CC- } \\
\text { South } \\
\text { Region }\end{array}$ & \\
\hline Allied Health & 9 & 13 & 12 & 7 & 15 & 6 & 62 \\
\hline Business & 12 & 12 & 10 & 5 & 23 & 17 & 79 \\
\hline Education & 6 & 0 & 3 & 3 & 0 & 2 & 14 \\
\hline Humanities & 21 & 8 & 16 & 20 & 12 & 19 & 96 \\
\hline $\begin{array}{l}\text { Social } \\
\text { Sciences }\end{array}$ & 12 & 6 & 8 & 22 & 12 & 23 & 83 \\
\hline Technology ${ }^{1}$ & 14 & 9 & 7 & 8 & 10 & 24 & 72 \\
\hline Math/Science ${ }^{2}$ & 14 & 7 & 9 & 10 & 6 & 13 & 59 \\
\hline College Totals & 88 & 55 & 65 & 75 & 78 & 104 & 465 \\
\hline
\end{tabular}

${ }^{1}$ May include courses for math/science (ex. statistics, research methods)

${ }^{2}$ May include courses for technology (for example, technical math)

Table 2 (based on general teaching area) shows the three major areas are the humanities (22.22\%), social sciences (15.08\%) and math/science (19.44\%).

Traditionally these areas are support areas for both the career and transfer programs.

Response numbers in this survey are consistent with that pattern. In addition, certain career pathways utilize several faculty members, and these are business $(16.67 \%$ of respondents) and allied health (15.08\% of respondents). Typically education areas at these colleges contain fewer faculty. This may be because only Community CollegeMid-Central has an elementary education program, and most of the respondents may come from one community college. Community College-South has one AAS program 
called early childhood education with only a few faculty members. All technology areas include computer science, which serves as a support course for most other teaching areas and programs. Table 2 shows the greatest response numbers from humanities and the lowest rate from education. This corresponds well with the overall numbers of faculty in those areas. In only the technology area does the response rate seem disproportionately low. In some cases, faculty, who are members in the technology area, are hired to teach mathematics or chemistry and physics and this may explain the differences between department and response numbers by teaching area.

Table 2

Response Frequencies by Department Areas (based on general teaching areas)

\begin{tabular}{|l|r|r|r|}
\hline Department & $\begin{array}{l}\text { Response } \\
\text { Frequency }\end{array}$ & $\begin{array}{l}\text { Response Rate } \\
\text { by Department. }\end{array}$ & $\begin{array}{l}\text { Overall } \\
\text { Response Rate }\end{array}$ \\
\hline Allied Health & 38 & $62.30 \%$ & $15.08 \%$ \\
\hline Business & 42 & $53.16 \%$ & $16.67 \%$ \\
\hline Education & 9 & $64.29 \%$ & $3.57 \%$ \\
\hline Humanities & 56 & $58.33 \%$ & $22.22 \%$ \\
\hline Social Sciences & 38 & $45.78 \%$ & $15.08 \%$ \\
\hline Technology & 20 & $27.78 \%$ & $7.94 \%$ \\
\hline Math/Science & 49 & $83.05 \%$ & $19.44 \%$ \\
\hline
\end{tabular}

Total $\mathrm{N}=252$

${ }^{1}$ May include courses for technology

In order to achieve the desired response rate, I used three contacts with each college. These included: 
Contact 1- All three chief academic officers gave permission to survey all faculty. Each faculty member received a letter indicating such agreement and the survey instrument and faculty profile in an addressed envelope. Each faculty member was asked to participate in the survey, with guaranteed confidentiality for the data collected. This contact netted at least a $50 \%$ return from all full-time faculty members at all three of the colleges. Contact 2-Each administrator in charge of faculty at the community colleges wrote a letter reminding all part-time faculty to turn in the surveys. Twenty extra packets for the study were provided to each school. This netted a few more responses, but the percentage of returns was still under $50 \%$ for each college.

Contact 3-Some variations in contacts

a.) The Dean at Community College-Mid-Central gave permission to seek responses from faculty who teach at night. I received the few extra responses needed to secure a $50 \%$ response rate.

b.) Community College-North Region held some orientation meetings for all part-time faculty on three consecutive evenings in June. This survey instrument was mentioned as one item on the agenda. By early July, I had the $50 \%$ response rate from Community College-North Region.

c.) The administrative secretary sent a new packet of survey information to all nonrespondents at their home address and from that, I received extra returns. However, I did not get a 50\% return rate from the part-time faculty at Community College-South Region; I got a $46 \%$ return rate. 


\section{Survey Instrument}

The "Inventories of Good Practice in Undergraduate Education" were generated from a 1986 project conducted under the auspices of the American Association for Higher Education, the Education Commission of the States, and the Johnson Foundation, Inc. Arthur W. Chickering of George Mason University, Zelda F. Gamson of the University of Massachusetts at Boston, and Louis M. Barsi of the American Association of State Colleges and Universities developed the Inventories, with the support of the Lilly Endowment. Susan J. Poulsen of the Johnson Foundation prepared the final inventories.

At the time of their development, the principles booklets did "represent the collective wisdom of colleagues who were knowledgeable about the research literature on the college experience" (Gamson, 1991, p.6). The faculty survey was based on the goal of identifying "practice, policies, and institutional conditions that would result in a powerful and enduring undergraduate education” (Sorcinelli, 1991, p.13).

Gamson (1991, p.10) reported that "response to the Inventories was overwhelming" and that "as of this writing, more that 500,000 Inventories have been requested. The response to the Seven Principles and the Inventories was so astonishing that it occasioned an article in the Chronicle of Higher Education." Gamson's article (p. 8) reported that colleges in other countries, Canada and the United Kingdom, ordered the Inventories. In addition, professors in Estonia and France began "creating versions to encourage improved teaching and learning in their institutions" (p. 11). 


\section{Validity of Survey Instrument}

One concern of the task force developing the inventories was for possible abuse of the work by administrations. However, "abuse of the inventories for evaluation purposes proved largely unfounded." People using the inventories know right from wrong and "if they had felt that the results would be for evaluation rather that improvement purpose, they could have easily altered their responses accordingly" (Gamson, 1991, p. 10). Moreover, the inventories themselves warn that the data are for self-improvement and not evaluation.

Relative to this study, the administrators (in the first follow-up letter) did ask that all faculty complete the inventory and suggested that the data might be useful only as part of their self-study for North Central Accreditation. However, no results on individual faculty members can be reported to the colleges since the researcher promised confidentiality to all participants, and all data will be presented in aggregate form only. Relating to the validity of the survey instrument, there are numerous instances of the inventories being used by colleges and universities in huge numbers. Originally the Johnson Foundation published the Seven Principles, and "more that 150,000 copies of the Seven Principles were ordered directly form the Johnson Foundation over the next eighteen months" and "as of this writing, more that 500,000 Inventories have been requested" (Gamson, 1991, p. 8 and p. 10).

Poulsen (1991) reports that one factor is clear. There is "endorsement of and commitment to the Principles and Inventories by the leaders within institutions, and a clearly expressed belief in the validity of these instruments" (p.35). 
In 1992, the Seven Principles Resource Center at Winoma State University took over publication and distribution of the Seven Principles inventories. The latest printing of the Student Inventory stated that "some 200,000 copies of the Seven Principles for Good Practice, and over 400,000 copies of the Inventories for Good Practice (Faculty and Institutional) have been distributed to colleges and universities across the United States and internationally in the past two years." The instrument is still being used, but not with such heavy volume. In 2003, Winoma State University shipped 6400 copies of the survey instrument for research use.

The Faculty Inventories for this study were purchased from the Resource Center at Winona State University in Winona, Minnesota. As stated earlier, the survey is still widely used and is recognized as showing validity.

\section{Data Analysis}

The purpose of this study was to investigate relative effectiveness of teaching between adjunct and full-time faculty in three community colleges as measured by seven indexes of good teaching practice. For this type of study, a t-test is appropriate and identifies significant differences in the means between the two sampled populations. The common significant difference values of $.05, .01$, and .001 were used. Means, frequencies, and t-tests were calculated for the statistical research questions 1-8. When appropriate, data were presented in tabular form and represented by overall college totals. The remaining research questions were qualitative.

Since mean values can be calculated for both adjunct and full-time faculty in each of the seven principles, a t-test can be calculated for each of the practices. There are also 10 sub-questions in each practice, and means can be calculated for each. By calculating a 
t-test for each practice, one may see the presence of significant differences. If there are differences, the sub-questions will help to isolate the exact area of difference.

Relative to the t-test and the difference between two means, the statistical test is valid "only if we could assume that the variances of the two samples are equal" (Sokal and Rohlf, 1969, p. 369). "Equality of variance in a group of samples is an important precondition for several statistical tests. Synonyms for this condition are homogeneity of variances or homoscedasticity" (p. 369). The "converse condition (inequality or variances among samples) is called heteroscedasticity" (p. 371).

With adjunct faculty, I did not assume that all of the adjunct faculty are equal in characteristics to the full-time faculty. In their 1993 book, The Invisible Faculty, Gappa and Leslie point out that adjunct faculty show "four major clusters of academic background, employment history, and motivations. ... We can see clearly that parttimers are not a monolithic group of marginal employees. We have identified four distinct sub-populations" (p. 45). For their book they grouped the part-timers into "four loose categories: career enders; specialists, experts, and professionals; aspiring academics; and freelancers" (p. 47). These authors state that career enders are often retired from careers outside of higher education and teach after their retirement. The specialists, experts, and professional category come from a wide range of areas and teach "for the love of it rather than because of a need for income" (p. 48); they teach in their specialty area but do not consider themselves to be college faculty. The group, called aspiring academics, do wish to be seen as "fully participating, recognized, rewarded members of the faculty with a status at least similar to that currently associated with the tenure-track or tenured faculty" (p. 48). For this one group, the variances within the two 
samples of full-time and part-time may be the same. The last group is the freelancers; they are not aspiring academics and are in higher education strictly by choice. For three sub-populations, other that the aspiring academics, the faculty have different desires and ambitions, and other occupations are their primary interest. In the Gappa and Leslie study, about $38-39 \%$ of the part-timers considered the community college to be their primary employment. The authors show "a good example of the mixture of part-timers among the different groups of part-timers in our interviews at one large community college" (p. 49). For the three groups other than aspiring academics, I assumed differences of variances, or heteroscedasticity. For analysis of the results, only those principles that showed significant difference in the t-test for both homoscedasticity and heteroscedasticity were considered to be different.

Likewise, overall data may be pooled to see if certain departments show significant differences in teaching practices. If such is the case, then developmental strategies may be used to help other faculty which need to improve in one or more practices of teaching. This study provides some interesting information to the chief academic officer about which teaching practices are used commonly and which practices need to be promoted with in-service programs or in teaching workshops.

\section{Summary}

This chapter has explained the methods used for the statistical part of the study on community college faculty. Research questions One through Seven, plus question Eight, are analyzed using the t-test. The other research questions (Nine and Ten) are analyzed by frequency distributions comparing the two samples and investigating general themes, but have no statistical results. The next chapter presents the results obtained. 


\section{CHAPTER 4: PRESENTATION AND ANALYSIS OF DATA}

As noted in Chapter 1, few research projects use adjunct teaching as a central focus, and even fewer have examined the quality of instruction by part-time faculty. This study examines the teaching practices of both adjunct and full-time faculty using the Faculty Inventory: Seven Principles for Good Practice in Undergraduate Education. For this study, the mean values and t-tests between full time and part time faculty members are calculated and compared. This chapter includes the population and the sample, the demographics of the sampled faculty, workshops and training offered these faculty members, the support services available to the faculty, the statistical analysis of data, the major findings, and a summary of the chapter.

\section{Population and Sample}

The population for this study included all faculty members from three community colleges of one state in Appalachia. Of the 465 faculty who received the survey, 252 responded based upon the initial surveys and two follow-up requests for additional responses.

Table 3 shows the percentage return rate for each college and for each category of faculty member. This table shows that the lowest percentage of the responses came from CCNR with $30.6 \%$ and the greatest return from CCSR with $35.2 \%$. In addition, the response rate ratio of full-time to part-time faculty is given. The percentages from each college show that only CCSR did not have $50 \%$ return rate for its part-time cadre.

For the frequency by status, the faculty ratio (full-time: part-time) is exactly $50 \%$ for both; that is, 126 respondents are full-time and 126 are part-time (Table 3). 
Table 3

Respondents to Survey

\begin{tabular}{|c|c|c|c|c|c|c|c|}
\hline \multirow[t]{2}{*}{ College } & \multirow{2}{*}{$\begin{array}{l}\text { Full- } \\
\text { time } \\
\text { Faculty }\end{array}$} & \multicolumn{2}{|c|}{ Full-time Response } & \multirow{2}{*}{$\begin{array}{l}\text { Part- } \\
\text { time } \\
\text { Faculty }\end{array}$} & \multicolumn{2}{|c|}{ Part-time Response } & \multirow{2}{*}{$\begin{array}{l}\text { \% of Total } \\
\text { Responses }\end{array}$} \\
\hline & & Responses & $\begin{array}{l}\% \\
\text { Response }\end{array}$ & & Responses & $\begin{array}{l}\% \\
\text { Response }\end{array}$ & \\
\hline $\mathrm{CCMC}$ & 88 & 46 & $52 \%$ & 75 & 40 & $53 \%$ & $34.13 \%$ \\
\hline CCNR & 55 & 38 & $69 \%$ & 78 & 39 & $50 \%$ & $30.56 \%$ \\
\hline CCSR & 65 & 42 & $65 \%$ & 104 & 47 & $46 \%$ & $35.22 \%$ \\
\hline total & 208 & $\mathrm{~N}=12$ & & 257 & $\mathrm{~N}=12$ & & \\
\hline
\end{tabular}

Faculty demographics are subdivided into ranges of years of experience:

probationary, mid-career, and long-term. See Table 4 for Demographics of Faculty.

In Table 4, some trends may be discerned with overall experience and community college experience subjugated to the undergraduate teaching experience of this study. At these three community colleges and considering undergraduate teaching experience, about $65 \%$ of the faculty have $7-42$ years of experience, suggesting a very stable, mature faculty. Over $40 \%$ (106 of the 252 respondents) have 16-42 years of experience, indicating much experience in education. This demographic suggests that these faculty members feel comfortable in higher education and have continued for years. Many of the part-time cadre also have experience of many years. For analysis in this study, years of experience in undergraduate teaching is calculated by adding community college and four-year and university teaching experience. 
For this experience factor, 88 of the 252 respondents (35\%) are new faculty with 1-6 years of undergraduate teaching experience, and about half of these newer faculty members are part-time staff. These three colleges have some newer, full-time and parttime faculty and a high number (65\%) of very experienced full-time faculty.

Concerning highest degree earned, almost $89 \%$ of the doctorates are for full-time faculty, and the bulk of the faculty holding the BS degrees $(68.4 \%)$ are part-time faculty. Approximately $11 \%$ of the faculty members at these community colleges hold the terminal degree. This tendency toward more academic preparation and higher credentials would seem logical for full-time faculty because certain disciplines have national standards for the teaching of transfer level courses; these standards require at least the master's degree. Career or certificate classes are more likely to be skill driven or based on a qualifying exam, and therefore may have fewer academic restrictions for instructors. The majority of the community college instructors hold the master's degree $(67 \%)$.

The faculty, both full-time and part-time, are about equally divided by gender. A cursory look at the distributions shows about equal spread between full-time and parttime faculty by gender. For this study, it is true that there are more female part-timers than male part-timers, but the difference is only 10 . There are more male full-time faculty than female full-time faculty, but the difference is only eight. So the stereotypical concept of a mostly male full-time faculty and many female adjuncts does not seem to apply in these community colleges. Each faculty category (by employment status and sex) represents at least $23.02 \%$ of the sample; this smallest group is male and part-time. 
From the data on tutoring students, two observations stand out: first, $60 \%$ of the part-time faculty do not tutor students, and secondly, $73 \%$ of the faculty tutors are fulltimers.

Concerning office hours, there are three prominent clusters of responses to office hours. Full-time faculty members at the CCMC college are required to have five hours a week in the office, the CCNR college requires seven and one-half office hours per week, and the CCSR college requires ten office hours per week. The responses reflect this requirement. In addition, 84 faculty members (all part-time) have no office hours per week and this represents $67 \%$ of the part-time cadre.

Table 4

Demographics of the Sampled Faculty

\begin{tabular}{|c|c|c|c|c|c|}
\hline \multirow[b]{2}{*}{ Characteristic } & \multicolumn{2}{|c|}{ Full-Time Faculty } & \multicolumn{2}{|c|}{ Part-Time Faculty } & \multirow[t]{2}{*}{ Total } \\
\hline & $\mathrm{N}$ & $\%$ of $\mathrm{N}$ & $\mathrm{N}$ & $\%$ of $\mathrm{N}$ & \\
\hline Total & 126 & $50.00 \%$ & 126 & $50.00 \%$ & 252 \\
\hline \multicolumn{6}{|c|}{ Teaching experience } \\
\hline 1-6 years & 22 & $37.93 \%$ & 36 & $62.07 \%$ & 58 \\
\hline $7-15$ years & 37 & $53.62 \%$ & 32 & $46.38 \%$ & 69 \\
\hline $16-42$ years & 67 & $53.60 \%$ & 58 & $46.40 \%$ & 125 \\
\hline \multicolumn{6}{|l|}{ CC Experience } \\
\hline $1-6$ years & 28 & $28.00 \%$ & 72 & $72.00 \%$ & 100 \\
\hline $7-15$ years & 51 & $70.83 \%$ & 21 & $29.17 \%$ & 72 \\
\hline $16-42$ years & 55 & $73.33 \%$ & 20 & $26.67 \%$ & 75 \\
\hline \multicolumn{6}{|c|}{ UG Teaching Experience } \\
\hline 1-6 years & 42 & $47.73 \%$ & 46 & $52.27 \%$ & 88 \\
\hline $7-15$ years & 29 & $50.00 \%$ & 29 & $50.00 \%$ & 58 \\
\hline $16-42$ years & 60 & $56.60 \%$ & 46 & $43.40 \%$ & 106 \\
\hline
\end{tabular}


Demographics of the Sampled Faculty (continued)

\begin{tabular}{|c|c|c|c|c|c|}
\hline \multirow[b]{2}{*}{ Characteristic } & \multicolumn{2}{|c|}{ Full-Time Faculty } & \multicolumn{2}{|c|}{ Part-Time Faculty } & \multirow{2}{*}{$\begin{array}{l}\text { Total } \\
\qquad \mathrm{N}\end{array}$} \\
\hline & $\mathrm{N}$ & $\%$ of $\mathrm{N}$ & $\mathrm{N}$ & $\%$ of $\mathrm{N}$ & \\
\hline \multicolumn{6}{|c|}{ Highest Degree } \\
\hline $\mathrm{PhD}$ & 24 & $88.89 \%$ & 3 & $11.11 \%$ & 27 \\
\hline BS & 12 & $31.57 \%$ & 26 & $68.42 \%$ & 38 \\
\hline MA & 20 & $48.78 \%$ & 21 & $51.22 \%$ & 41 \\
\hline MS & 68 & $52.71 \%$ & 61 & $47.29 \%$ & 129 \\
\hline \multicolumn{6}{|l|}{ Gender } \\
\hline Female & 59 & $23.41 \%$ & 68 & $26.98 \%$ & 127 \\
\hline Male & 67 & $26.51 \%$ & 58 & $23.02 \%$ & 125 \\
\hline \multicolumn{6}{|l|}{ Tutor students } \\
\hline No & 70 & $40.23 \%$ & 104 & $59.77 \%$ & 174 \\
\hline Yes & 57 & $73.08 \%$ & 21 & $26.92 \%$ & 78 \\
\hline \multicolumn{6}{|l|}{ Office Hours } \\
\hline O hours & & & 84 & $100 \%$ & 84 \\
\hline $1-2$ & & & 22 & $100 \%$ & 22 \\
\hline $3-4$ & & & 6 & $100 \%$ & 6 \\
\hline 5 & 26 & $92.86 \%$ & 2 & $7.14 \%$ & 28 \\
\hline $6-7$ & 7 & $50 \%$ & 7 & $50 \%$ & 14 \\
\hline 8 & 38 & $90.48 \%$ & 4 & $9.52 \%$ & 42 \\
\hline 10 & 36 & $90 \%$ & 4 & $10 \%$ & 40 \\
\hline over 10 & 15 & $93.75 \%$ & 1 & $6.25 \%$ & 16 \\
\hline
\end{tabular}

As stated in Chapter 1, colleges and universities need to invest in their human resources and allow better integration of the part-time faculty into the institution. Part of the survey's profile asked for faculty members to identify workshops and training they received from the college (Table 5).

The most frequently attended workshops are on technology $(56 \%)$, orientation to the college (49\%), syllabus development (47\% and required by a few departments), and workshop on advising (43\%). However, only the workshop on technology shows more respondents who attended than those who did not attend. Since technology can apply 
directly to the classroom, the faculty appears interested in any training that can be used directly for their courses.

High numbers of part-time faculty did not attend workshops on grading, planning curricula, writing exams, and advising. Perhaps the workshops were at inconvenient times or the adjunct group did not see these training sessions as a responsibility. In many cases, these workshops are offered during the beginning of semester in-service period when full-time faculty are required to be on campus, but the adjunct faculty are not. In many cases, these workshops are used to help the full-time faculty develop a skill, such as adherence to the uniform course syllabus requirement while the general syllabus may be dictated for the part-time instructors. For example, in many math courses, the general rules, time allotted per topic, and requirements for the course are set by the full-time faculty and the syllabus is then given to the part-time instructor, who may add a few modifications.

Overall, workshops offered by these three community colleges are not well attended, yet are rated highly. Workshop scores are excellent (1), very good (2), and average (3), below average (4), and poor (5) and means given by attendees are all between very good or average. It seems that faculty who attend appreciate the training. 
Table 5

Workshops and Training for Faculty

\begin{tabular}{|c|c|c|c|c|c|}
\hline \multirow[b]{2}{*}{$\begin{array}{l}\text { Workshop or } \\
\text { Training }\end{array}$} & \multicolumn{2}{|c|}{ Yes - Attended } & \multicolumn{2}{|c|}{$\begin{array}{l}\text { No-Did Not } \\
\text { Attend }\end{array}$} & \multirow[b]{2}{*}{ Means - Workshop rating } \\
\hline & $\mathrm{N}$ & $\%$ & $\mathrm{~N}$ & $\%$ & \\
\hline Workshop-grading & $\begin{array}{c}20 \\
\text { FT-7 } \\
\text { PT-13 } \\
\end{array}$ & $7.94 \%$ & $\begin{array}{c}232 \\
\text { FT-119 } \\
\text { PT-113 }\end{array}$ & $92.06 \%$ & 3.00 \\
\hline $\begin{array}{l}\text { Planning curricula } \\
\text { Workshop }\end{array}$ & $\begin{array}{c}45 \\
\text { FT-29 } \\
\text { PT-16 }\end{array}$ & $17.86 \%$ & $\begin{array}{c}207 \\
\text { FT-97 } \\
\text { PT-110 }\end{array}$ & $82.14 \%$ & 2.87 \\
\hline $\begin{array}{l}\text { Syllabus } \\
\text { development }\end{array}$ & $\begin{array}{c}118 \\
\text { FT-73 } \\
\text { PT-45 }\end{array}$ & $46.83 \%$ & $\begin{array}{c}134 \\
\text { FT-53 } \\
\text { PT-81 }\end{array}$ & $53.17 \%$ & 2.97 \\
\hline $\begin{array}{l}\text { Writing exams } \\
\text { Workshop }\end{array}$ & $\begin{array}{c}27 \\
\text { FT-19 } \\
\text { PT-8 } \\
\end{array}$ & $10.71 \%$ & $\begin{array}{c}225 \\
\text { FT-107 } \\
\text { PT-118 }\end{array}$ & $89.29 \%$ & 2.89 \\
\hline $\begin{array}{l}\text { Orientation to the } \\
\text { college }\end{array}$ & $\begin{array}{c}123 \\
\text { FT-68 } \\
\text { PT-55 } \\
\end{array}$ & $48.81 \%$ & $\begin{array}{c}129 \\
\text { FT-58 } \\
\text { PT-71 } \\
\end{array}$ & $51.19 \%$ & 2.52 \\
\hline Mentors & $\begin{array}{c}50 \\
\text { FT-23 } \\
\text { PT-27 }\end{array}$ & $19.84 \%$ & $\begin{array}{c}202 \\
\text { FT-103 } \\
\text { PT-99 }\end{array}$ & $80.16 \%$ & 2.63 \\
\hline $\begin{array}{l}\text { Workshop on } \\
\text { Teaching }\end{array}$ & $\begin{array}{c}86 \\
\text { FT-55 } \\
\text { PT-31 } \\
\end{array}$ & $34.13 \%$ & $\begin{array}{c}166 \\
\text { FT-71 } \\
\text { PT-95 } \\
\end{array}$ & $65.87 \%$ & 2.54 \\
\hline $\begin{array}{l}\text { Workshop on } \\
\text { advising }\end{array}$ & $\begin{array}{c}108 \\
\text { FT-81 } \\
\text { PT-27 } \\
\end{array}$ & $42.86 \%$ & $\begin{array}{c}144 \\
\text { FT-45 } \\
\text { PT-99 } \\
\end{array}$ & $57.14 \%$ & 2.97 \\
\hline $\begin{array}{l}\text { Workshop on } \\
\text { technology }\end{array}$ & $\begin{array}{c}142 \\
\text { FT-97 } \\
\text { PT-45 } \\
\end{array}$ & $56.35 \%$ & $\begin{array}{c}110 \\
\text { FT-29 } \\
\text { PT-81 } \\
\end{array}$ & $43.65 \%$ & 2.64 \\
\hline
\end{tabular}

$\mathrm{FT}=$ fulltime $\quad \mathrm{PT}=$ part-time

Colleges provide certain assistance to all faculty for teaching their classes and

Table 6 shows these support services. The services most frequently reported by both groups are access to equipment and $\mathrm{A}-\mathrm{V}$ equipment in particular. The next most common services offered are secretarial help and e-mail access. Having a phone and an 
office are supplied at lower rates. In every category, the full-time faculty report a higher incidence for receiving the support service than do the part-time instructors. For the phone and email use categories, the overall percentages appear about the same.

Overwhelming numbers of full-timers have these services, but only one-fifth of the parttimers answer "yes" to having both phone and email support.

In two other support services, access to equipment and $\mathrm{A}-\mathrm{V}$ use, the percentages indicating support are almost identical. Almost all full-time (48\% of the $50 \%$ respondents) and slightly less (41\% of the $50 \%$ part-time respondents) report support in these areas; together $89 \%$ of faculty have assistance here. Thus it seems that equipment is available to use if the faculty desire it. Equipment is available for faculty members, but explanation of its use and help with the A-V equipment receive lower ratings. Only $50.4 \%$ of respondents have explanations in using the technology equipment and $60.4 \%$ have A-V help.

In the two categories of office space and secretarial help, $66 \%$ of all faculty report having these services, yet almost all of full-timers report offices with only $17 \%$ of parttimers reporting offices. Clearly it is full-timers, not part-timers, who enjoy most of these support services. 
Table 6.

Support Services for Faculty

\begin{tabular}{|l|c|c|c|l|c|c|c|c|c|c|}
\hline $\begin{array}{l}\text { Support } \\
\text { Feature }\end{array}$ & \multicolumn{5}{|c|}{ Yes (Provided Support) } & \multicolumn{3}{c|}{ No (Did Not Receive Support) } \\
\hline & Full-time & Part-time & Total & Full-time & \multicolumn{2}{l|}{ Part-time } & Total \\
\hline & $\mathrm{N}$ & $\%$ & $\mathrm{~N}$ & $\%$ & & $\mathrm{~N}$ & $\%$ & $\mathrm{~N}$ & $\%$ & \\
\hline $\begin{array}{l}\text { Tour of } \\
\text { Facility }\end{array}$ & 48 & $19.20 \%$ & 37 & $14.80 \%$ & 85 & 76 & $30.16 \%$ & 89 & $35.32 \%$ & 165 \\
\hline Phone to Use & 123 & $49.40 \%$ & 51 & $20.48 \%$ & 174 & 1 & $0.40 \%$ & 74 & $29.37 \%$ & 75 \\
\hline $\begin{array}{l}\text { Email Access } \\
\text { at College }\end{array}$ & 123 & $49.20 \%$ & 55 & $22.00 \%$ & 178 & 1 & $0.40 \%$ & 71 & $29.37 \%$ & 72 \\
\hline $\begin{array}{l}\text { Access to } \\
\text { Equipment }\end{array}$ & 120 & $48.00 \%$ & 101 & $40.40 \%$ & 221 & 4 & $1.59 \%$ & 25 & $9.92 \%$ & 29 \\
\hline $\begin{array}{l}\text { Explanation } \\
\text { of Equipment }\end{array}$ & 73 & $29.30 \%$ & 53 & $21.20 \%$ & 126 & 51 & $20.24 \%$ & 73 & $28.97 \%$ & 124 \\
\hline \begin{tabular}{l} 
Office Space \\
\hline
\end{tabular} & 122 & $48.80 \%$ & 43 & $17.20 \%$ & 165 & 2 & $0.79 \%$ & 83 & $32.94 \%$ & 85 \\
\hline $\begin{array}{l}\text { Secretarial } \\
\text { Help }\end{array}$ & 103 & $41.20 \%$ & 77 & $30.80 \%$ & 180 & 21 & $8.33 \%$ & 49 & $19.44 \%$ & 70 \\
\hline $\begin{array}{l}\text { Use of A-V } \\
\text { Equpment }\end{array}$ & 119 & $47.60 \%$ & 103 & $41.20 \%$ & 222 & 5 & $1.98 \%$ & 23 & $9.13 \%$ & 28 \\
\hline $\begin{array}{l}\text { A-V Help to } \\
\text { Use }\end{array}$ & 92 & $36.80 \%$ & 59 & $23.60 \%$ & 151 & 32 & $12.70 \%$ & 67 & $26.59 \%$ & 99 \\
\hline
\end{tabular}

\section{Data Reporting}

There are 10 research questions, with two yielding general qualitative data about teaching supports and interventions, policies, concerns, and needs for community college faculty. These two (Research Questions Nine and Ten) will be discussed last. The eight statistical Research Questions (Research Questions 1-8) will be analyzed first.

Data for the first seven questions will be reported as:

n (full-time number), M (mean full-time), SD (Standard Deviation full-time) $\mathrm{n}$ (part-time number), M (mean part-time), SD (Standard Deviation part-time) t-test values with significance noted as $.05^{*}, .01^{* *}$, or $.001^{* * *}$ 
In the faculty inventory, the responses for using the good practices are labeled as very often (coded 1), often (coded 2), occasionally (coded 3), rarely (coded 4), and never (coded 5). A lower mean number indicates that the faculty member uses that practice more often. Only when there is significance in all three categories (t-test, homoscedasticity, heteroscedasticity) will the practice be considered as significant.

\section{Research Question 1 - Principle 1: Student-Faculty Contact}

In Table 7, seven of the ten subcategories show significant differences. In each case, full-time faculty are significantly more involved in encouraging contact with students.

The significant practices are given in order of most significance level:

1. I advise my students about career opportunities in their major field.

2. Students drop by my office just to visit.

8. I serve as mentor or informal advisor to students.

9. I take students to professional meetings or other events in my field.

4. I attend events sponsored by student groups.

5. I work with student affairs staff on issues related to student extracurricular life and life outside the school.

10. Whenever there is a conflict on campus involving students, I try to help in its resolution.

Several of these practices involve communication with students about the course or the potential profession. Full-time faculty give more advice about careers, entertain more student visits, act as mentors, or take students to professional meetings. They also interact more than their counterparts with students at student events, and work more frequently on student affairs outside the classroom. In four areas, both full-time and parttime faculty show averages indicating occasional or rare practices (means greater than 2.5). These more rarely practiced areas are: attending events sponsored by students, working with student affairs staff on issues of extracurricular life, taking students to professional events, and helping with campus conflicts involving students. However, the 
mean scores for part-time faculty in subcategory 3 (sharing my experiences with students) and 6 (knowing student names by end of the first two weeks) are noteworthy, if not significant.

\section{Table 7}

Encourages student-faculty contact by full-time and part-time faculty

\begin{tabular}{|l|c|c|c|c|c|c|c|}
\hline Practice One & $\begin{array}{r}\text { FT } \\
\text { 1 Career advice }\end{array}$ & $\begin{array}{r}\text { FT } \\
\text { M }\end{array}$ & $\begin{array}{c}\text { FT } \\
\text { SD }\end{array}$ & $\begin{array}{r}\text { PT } \\
\text { N }\end{array}$ & $\begin{array}{c}\text { PT } \\
\text { M }\end{array}$ & $\begin{array}{c}\text { PT } \\
\text { SD }\end{array}$ & $\begin{array}{c}\text { t-value } \\
\text { sign. }\end{array}$ \\
\hline 2 Office visits & 126 & 1.754 & 0.8264 & 119 & 2.311 & 0.8996 & $0.0000^{* * *}$ \\
\hline 3 Share experiences & 126 & 1.992 & 0.9252 & 93 & 2.839 & 1.2962 & $0.0000^{* * *}$ \\
\hline 4 Attend events & 126 & 2.690 & 0.9917 & 115 & 3.261 & 1.2289 & $0.0001^{* * *}$ \\
\hline 5 Student issues & 124 & 3.274 & 1.0068 & 109 & 3.853 & 1.3040 & $0.0002^{* * *}$ \\
\hline 6 Know by name & 126 & 1.754 & 0.9268 & 119 & 1.790 & 0.9731 & 0.7677 \\
\hline 7 Different cultures & 121 & 2.256 & 1.1513 & 113 & 2.292 & 1.2584 & 0.8208 \\
\hline 8 Mentor & 126 & 1.889 & 0.9141 & 116 & 2.535 & 1.2331 & $0.0000^{* * *}$ \\
\hline 9 Professional trips & 125 & 3.480 & 1.2927 & 110 & 4.200 & 1.0649 & $0.0000^{* * *}$ \\
\hline 10 Campus conflict & 121 & 2.851 & 1.1523 & 106 & 3.368 & 1.3545 & $0.0024 * *$ \\
\hline
\end{tabular}




\section{Research Question 2 - Principle 2: Encourages Cooperation Among Students}

Table 8 shows the statistical results in this area of good practice; three activities show significant differences, with full-time faculty showing more usage than part-time in these areas:

8. I create "learning communities," study groups, or project teams within my courses.

3. I encourage students to do projects together.

9. I encourage students to join at least one campus organization.

Overall for this practice, both categories of faculty seem to encourage cooperation among students. The highest means for either group show up as 3.024 and 3.364 (coded as occasional use) and this practice is for encouraging students to join one organization. 
Table 8

Encourages cooperation among students by full-time and part-time faculty

\begin{tabular}{|l|c|c|c|c|c|c|c|}
\hline Practice Two & $\begin{array}{r}\text { FT } \\
\text { N }\end{array}$ & $\begin{array}{c}\text { FT } \\
\text { M }\end{array}$ & $\begin{array}{r}\text { FT } \\
\text { SD }\end{array}$ & $\begin{array}{r}\text { PT } \\
\text { N }\end{array}$ & $\begin{array}{c}\text { PT } \\
\text { M }\end{array}$ & $\begin{array}{c}\text { PT } \\
\text { SD }\end{array}$ & $\begin{array}{c}\text { t-value } \\
\text { sign. }\end{array}$ \\
\hline 2 Work together & 125 & 2.360 & 1.1598 & 119 & 2.429 & 1.0216 & 0.6241 \\
\hline 3 Do team projects & 126 & 1.635 & 0.7653 & 119 & 1.815 & 0.8230 & 0.0776 \\
\hline 4 Evaluate work & 126 & 2.984 & 1.2648 & 117 & 3.137 & 1.3576 & 0.3665 \\
\hline 5 Explain ideas & 126 & 2.238 & 0.9669 & 118 & 2.331 & 0.9157 & 0.4440 \\
\hline 6 Praise each other & 126 & 2.524 & 1.1364 & 119 & 2.487 & 1.0960 & 0.7987 \\
\hline 7 Different views & 123 & 2.577 & 1.1453 & 114 & 2.561 & 0.9959 & 0.9095 \\
\hline 8 Study groups & 125 & 2.448 & 1.2012 & 116 & 2.828 & 1.1593 & $0.0185^{*}$ \\
\hline 9 Join organization & 126 & 3.024 & 1.3533 & 110 & 3.364 & 1.2615 & $0.0472^{*}$ \\
\hline 10 Independent grade & 123 & 1.870 & 1.2008 & 109 & 2.321 & 1.4134 & 0.0613 \\
\hline
\end{tabular}

\section{Research Question 3 - Principle 3: Encourages Active Learning}

Table 9 shows statistics for Practice Three, encouraging active learning in the classroom. Although adjuncts and full-time faculty use a variety of active learning techniques with similar general frequency, only three practices show significant differences, with the full-time faculty showing the more frequent use for these:

9. My students and I arrange field trips, volunteer activities, or internships related to the course.

8. I encourage my students to suggest new readings, research projects, field trips, or other course activities.

5. I encourage my students to challenge my ideas, ideas of other students, or those of course readings. 
In these three instructional areas, the part-time instructors show less implementation for using outside activities than do full-time faculty. In addition, fulltime faculty employ more innovation regarding new or challenging ideas in the classroom. Neither group appears to use course trips or research projects with regularity. Table 9

Encourages active learning by full-time and part-time faculty

\begin{tabular}{|l|c|c|c|c|c|c|l|}
\hline Practice Three & $\begin{array}{c}\text { FT } \\
\text { N }\end{array}$ & $\begin{array}{c}\text { FT } \\
\text { M }\end{array}$ & $\begin{array}{c}\text { FT } \\
\text { SD }\end{array}$ & $\begin{array}{c}\text { PT } \\
\text { N }\end{array}$ & $\begin{array}{c}\text { PT } \\
\text { M }\end{array}$ & $\begin{array}{c}\text { PT } \\
\text { SD }\end{array}$ & $\begin{array}{c}\text { t-value } \\
\text { sign. }\end{array}$ \\
\hline 1 Present work & 126 & 2.413 & 0.9738 & 116 & 2.474 & 1.0339 & 0.6353 \\
\hline 2 Different work & 123 & 2.650 & 1.2413 & 113 & 2.903 & 1.1647 & 0.1086 \\
\hline 3 Outside relevance & 125 & 1.936 & 0.9310 & 116 & 1.966 & 0.8938 & 0.8020 \\
\hline 4 Research studies & 124 & 2.419 & 1.1554 & 114 & 2.518 & 1.1070 & 0.5039 \\
\hline 5 Challenge ideas & 124 & 1.911 & 0.8927 & 116 & 2.190 & 1.0036 & $0.0245^{*}$ \\
\hline 6 Real-life issues & 125 & 1.576 & 0.7434 & 116 & 1.603 & 0.6963 & 0.7675 \\
\hline 7 Role-playing & 126 & 2.159 & 1.2987 & 117 & 2.410 & 1.2117 & 0.1196 \\
\hline 8 Suggest activities & 124 & 2.605 & 1.0956 & 115 & 2.974 & 1.2173 & $0.0273^{*}$ \\
\hline 9 Course trips & 125 & 3.224 & 1.3129 & 109 & 3.881 & 1.2452 & $0.0001^{* * *}$ \\
\hline 10 Research Projects & 124 & 3.540 & 1.2520 & 112 & 3.509 & 1.3423 & 0.8532 \\
\hline
\end{tabular}

\section{Research Question 4 - Principle 4: Gives Prompt Feedback}

As seen in Table 10, full-time and part-time instructors appear very similar in most practices relating to prompt feedback. In only two subcategories, data show significance with full-time faculty showing more frequency for these: 
5. I ask students to schedule conferences with me to discuss progress.

7. I give my students a pre-test at the beginning of each course.

For this practice, neither the full-time nor the part-time faculty report high usage (means of 2.5 or less) for the last four subcategories in this area. Most community college faculty in this study do not use a pre-test at the beginning of each course, do not ask students to keep written logs and records of their progress, do not discuss the final examination with students, and do not call or write notes to students who miss class. Full-time and part-time faculty show much similarity in this good practice and both significance levels are lower (.05) for this good practice.

Table 10

Gives prompt feedback by full-time and part-time faculty

\begin{tabular}{|l|c|c|c|c|c|c|c|}
\hline Practice Four & $\begin{array}{c}\text { FT } \\
\text { N }\end{array}$ & $\begin{array}{c}\text { FT } \\
\text { M }\end{array}$ & $\begin{array}{c}\text { FT } \\
\text { SD }\end{array}$ & $\begin{array}{c}\text { PT } \\
\text { N }\end{array}$ & $\begin{array}{c}\text { PT } \\
\text { M }\end{array}$ & $\begin{array}{c}\text { PT } \\
\text { SD }\end{array}$ & $\begin{array}{c}\text { t-value } \\
\text { sign. }\end{array}$ \\
\hline 1 Quiz/homework & 126 & 1.437 & 0.8246 & 117 & 1.607 & 0.8505 & 0.1148 \\
\hline 2 Immediate results & 126 & 1.492 & 0.7238 & 117 & 1.538 & 0.7015 & 0.6124 \\
\hline 3 Return in week & 126 & 1.254 & 0.6058 & 116 & 1.276 & 0.5530 & 0.7691 \\
\hline 4 Evaluate in detail & 125 & 1.544 & 0.7014 & 116 & 1.647 & 0.7010 & 0.2578 \\
\hline 5 Conferences & 126 & 2.008 & 0.9674 & 113 & 2.301 & 1.1408 & $0.0344^{*}$ \\
\hline 6 Written comments & 126 & 1.635 & 0.8909 & 116 & 1.905 & 1.0128 & 0.0560 \\
\hline 7 Pre-tests & 124 & 3.121 & 1.3103 & 115 & 3.496 & 1.4592 & $0.0384^{*}$ \\
\hline 8 Logs and records & 126 & 2.921 & 1.4345 & 113 & 3.009 & 1.4299 & 0.6349 \\
\hline 9 Final results & 124 & 3.185 & 1.4221 & 112 & 3.161 & 1.2844 & 0.8883 \\
\hline 10 Notes if absent & 126 & 2.984 & 1.1865 & 114 & 3.158 & 1.1868 & 0.2584 \\
\hline
\end{tabular}




\section{Research Question 5 - Principle 5: Emphasizes Time on Task}

Results for this good practice show significant differences in six areas (see Table 11).

Full-time faculty members show greater frequency for:

8. I make it clear that full-time study is a full-time job that requires 40 or more hours a week.

2. I clearly communicate to my students the minimum amount of time they should spend preparing for class.

3. I make clear to my students the amount of time this is required to understand complex material.

6. I underscore the importance of regular work, steady application, sound selfpacing, and scheduling.

7. I explain to my students the consequences of non-attendance.

9. I meet with students who fall behind to discuss their study habits, schedules, and other commitments.

For the differences in this good practice, it seems obvious that full-time faculty communicate (make it clear, clearly communicate, underscore, explain, again make it clear, and discuss) more frequently the amount of time needed to complete certain coursework. However, both groups have means under 2.5 in every subcategory; both groups explain time on task very well for their students. 
Table 11

Emphasizes time on task by full-time and part-time faculty

\begin{tabular}{|l|c|c|c|c|c|c|c|}
\hline Practice Five & $\begin{array}{c}\text { FT } \\
\text { N }\end{array}$ & $\begin{array}{c}\text { FT } \\
\text { M }\end{array}$ & $\begin{array}{c}\text { FT } \\
\text { SD }\end{array}$ & $\begin{array}{c}\text { PT } \\
\text { N }\end{array}$ & $\begin{array}{c}\text { PT } \\
\text { M }\end{array}$ & $\begin{array}{c}\text { PT } \\
\text { SD }\end{array}$ & $\begin{array}{c}\text { t-value } \\
\text { sign. }\end{array}$ \\
\hline 2 Time to spend & 125 & 1.208 & 0.4268 & 116 & 1.164 & 0.4159 & 0.4164 \\
\hline 3 Amount of time & 125 & 1.472 & 0.6669 & 116 & 1.759 & 0.9383 & $0.0072^{* *}$ \\
\hline 4 Challenging goals & 124 & 1.774 & 0.7844 & 115 & 1.913 & 0.8009 & 0.1775 \\
\hline 5 Rehearse for class & 119 & 2.185 & 1.1858 & 107 & 2.234 & 1.2482 & 0.7642 \\
\hline 6 Emphasis-work & 124 & 1.395 & 0.6223 & 115 & 1.609 & 0.8345 & $0.0268^{*}$ \\
\hline 7 Non-attendance & 124 & 1.234 & 0.5426 & 116 & 1.431 & 0.8046 & $0.0282^{*}$ \\
\hline 8 Full-time study & 122 & 1.631 & 0.9552 & 114 & 2.281 & 1.3271 & $0.0000^{* * *}$ \\
\hline 9 Meet if behind & 124 & 2.040 & 0.9491 & 114 & 2.333 & 1.1341 & $0.0325^{*}$ \\
\hline \\
10 Make-up work
\end{tabular}

\section{Research Question 6 - Principle 6: Communicates High Expectations}

In three separate subcategories, the data show significant differences with the fulltime faculty reporting greater utilization. These significant areas seen in Table 12 are:

9. I revise my courses.

5. I explain to students what will happen if they do not complete their work on time.

1. I tell students that I expect them to work hard in my classes.

In two of these subcategories, words such as "tell" and "explain" indicate communication issues and seem very similar to those in good practice Five where data show that the full-time staff communicate more often to students than do the part-time faculty. Subcategory nine is not a communication issue; it is a procedural topic, 
regarding how the faculty member handles the course over a period of years. In addition, the data show that both groups are very good at communicating high expectations to their students. All data, for both groups, have means of less than 2.5 in every single subcategory.

Table 12

Communicates high expectations by full-time and part-time faculty

\begin{tabular}{|l|c|c|c|c|c|c|c|}
\hline Practice Six & FT & $\begin{array}{c}\text { FT } \\
\text { N }\end{array}$ & $\begin{array}{c}\text { FT } \\
\text { SD }\end{array}$ & $\begin{array}{c}\text { PT } \\
\text { N }\end{array}$ & $\begin{array}{c}\text { PT } \\
\text { M }\end{array}$ & $\begin{array}{c}\text { PT } \\
\text { SD }\end{array}$ & $\begin{array}{c}\text { t-value } \\
\text { sign. }\end{array}$ \\
\hline 1 Give expectations & 125 & 1.224 & 0.4555 & 115 & 1.365 & 0.5671 & $0.0355^{*}$ \\
\hline 2 Set high standards & 125 & 1.272 & 0.5590 & 115 & 1.322 & 0.5856 & 0.5024 \\
\hline 3 Oral/written goals & 125 & 1.184 & 0.5141 & 116 & 1.138 & 0.3463 & 0.4125 \\
\hline 4 Set goals & 122 & 1.738 & 0.8411 & 114 & 1.763 & 0.6823 & 0.7982 \\
\hline 5 Incomplete work & 125 & 1.264 & 0.5700 & 116 & 1.448 & 0.7144 & $0.0286^{*}$ \\
\hline 6 Extra tasks & 124 & 2.073 & 1.0215 & 112 & 2.268 & 1.0396 & 0.1476 \\
\hline 7 Writing & 123 & 2.065 & 1.0460 & 114 & 2.193 & 1.1200 & 0.3654 \\
\hline 8 Note excellence & 125 & 2.080 & 1.0895 & 115 & 1.983 & 0.9732 & 0.4653 \\
\hline 9 Revisions & 125 & 1.368 & 0.5318 & 114 & 1.711 & 0.9094 & $0.0006^{* * *}$ \\
\hline 10 Progress in class & 125 & 1.544 & 0.6538 & 116 & 1.724 & 0.7293 & 0.0642 \\
\hline
\end{tabular}

\section{Research Question 7 - Principle 7: Respects Diverse Talents and Ways of Learning}

In Table 13 for good practice seven, three subcategories show significant differences with the full-time faculty again reporting the higher use. These are: 
8. I have developed mastery learning, learning contracts, or computer assisted learning alternatives for my courses.

6. I integrate new knowledge about women and other under-represented populations into my courses.

1. I encourage students to speak up when they do not understand.

Subcategories eight and six involve techniques to introduce additional content or additional learning techniques into the course. These data suggest that adjuncts show less innovation in the classroom, both in selecting and expanding content and in trying alternative means of presentation. Item 1 is a communication issue and data from this study consistently suggest that adjuncts do not promote as much communication with students as do full-time faculty; results in this subcategory correspond well with significant differences for Practice One and Practice Five in this study.

In three areas of practice (subcategories seven to nine), both groups show lower incidences for practices. Both groups show much lower (occasional or rare) means for providing independent studies for students (Item 7), for developing alternative learning methods (Item 8), and for encouraging students to design their own majors (Item 9). 
Table 13

Respects diverse talents and ways of learning by full-time and part-time faculty

\begin{tabular}{|l|c|c|c|c|c|c|c|}
\hline Practice Seven & $\begin{array}{r}\text { FT } \\
\text { N }\end{array}$ & $\begin{array}{r}\text { FT } \\
\text { M }\end{array}$ & $\begin{array}{r}\text { FT } \\
\text { SD }\end{array}$ & $\begin{array}{r}\text { PT } \\
\text { N }\end{array}$ & $\begin{array}{r}\text { PT } \\
\text { M }\end{array}$ & $\begin{array}{c}\text { PT } \\
\text { SD }\end{array}$ & $\begin{array}{c}\text { t-value } \\
\text { sign. }\end{array}$ \\
\hline 2 Do not embarrass & 126 & 1.159 & 0.4082 & 117 & 1.291 & 0.5262 & $0.0310^{*}$ \\
\hline 3 Diverse methods & 124 & 1.452 & 0.7999 & 116 & 1.569 & 0.8770 & 0.2809 \\
\hline 4 Backgrounds & 122 & 2.041 & 1.1164 & 112 & 2.277 & 1.0672 & 0.1000 \\
\hline 5 Extra help & 126 & 2.056 & 0.9575 & 114 & 2.246 & 1.0607 & 0.1480 \\
\hline 6 Minority data & 122 & 2.352 & 1.2722 & 110 & 2.736 & 1.2756 & $0.0228^{*}$ \\
\hline 7 Independent work & 125 & 2.968 & 1.310 & 110 & 2.855 & 1.3803 & 0.5190 \\
\hline 8 Alternatives used & 125 & 2.936 & 1.2747 & 113 & 3.469 & 1.4582 & $0.0031^{* *}$ \\
\hline 9 Own majors & 117 & 3.308 & 1.4048 & 103 & 3.748 & 1.3700 & 0.0758 \\
\hline 10 Students' interest & 126 & 2.040 & 1.0688 & 115 & 1.983 & 1.0086 & 0.6702 \\
\hline
\end{tabular}

\section{Research Question 8}

8. Are there significant differences in good teaching practices based on demographic characteristics of the faculty (for example, by sex or by years of experience or by academic area)?

\section{A. Differences by sex of instructor:}

Results for gender differences are reported as:

Number-female, Mean-female, Standard Deviation-female Number-male, Mean-male, Standard Deviation-male t-value/ Significance

Significance levels-.05*,.01**,.001*** 
Practice One evaluates Student-Faculty Contact and three areas show females with significantly higher frequency of practice than exhibited by male faculty (see Table 14). These are:

6. I know my students by name by the end of the first two weeks.

9. I take students to professional meetings or other events in my field.

4. I attend events sponsored by student groups.

The data suggest that women are more serious about getting to know their students both in the classroom (know student names) and outside of the class (at student events or as chaperone to professional events). Females in this study report more interaction with students.

In four subcategories $(4,5,9$, and 10$)$, neither sex shows high frequency for practice. For items 4 and 10, the means show only the score of "occasional" for attending events sponsored by student groups or showing involvement in campus conflict about students. For the two other practices, the means show "rarely" as the usual frequency of practice for working with staff about student issues (Item 5) and for taking students on professional trips (Item 9). 
Table 14

Encourages student-faculty contact by gender of faculty member

\begin{tabular}{|l|l|l|l|l|l|l|l|}
\hline \multicolumn{1}{|c|}{ Practice One } & $\begin{array}{c}\text { Female } \\
\mathrm{N}\end{array}$ & $\begin{array}{c}\text { Female } \\
\mathrm{M}\end{array}$ & $\begin{array}{c}\text { Female } \\
\text { SD }\end{array}$ & $\begin{array}{c}\text { Male } \\
\mathrm{N}\end{array}$ & $\begin{array}{c}\text { Male } \\
\mathrm{M}\end{array}$ & $\begin{array}{c}\text { Male } \\
\text { SD }\end{array}$ & $\begin{array}{c}\text { t-value } \\
\text { Sign. }\end{array}$ \\
\hline 1 Career advice & 121 & 2.008 & 0.9089 & 123 & 2.033 & 0.9048 & 0.8346 \\
\hline 2 Office visits & 105 & 2.219 & 1.1765 & 114 & 2.474 & 1.1614 & 0.1089 \\
\hline 3 Share experiences & 122 & 1.721 & 0.8258 & 124 & 1.742 & 0.8349 & 0.8457 \\
\hline 4 Attend events & 118 & 2.805 & 1.1037 & 123 & 3.114 & 1.1679 & $0.0359^{*}$ \\
\hline 5 Student issues & 114 & 3.614 & 1.1328 & 119 & 3.479 & 1.2409 & 0.3862 \\
\hline 6 Know by name & 123 & 1.610 & 0.8649 & 122 & 1.934 & 1.0020 & $0.0071^{* *}$ \\
\hline 7 Different cultures & 116 & 2.250 & 1.1487 & 118 & 2.297 & 1.2562 & 0.7673 \\
\hline 8 Mentor & 121 & 2.116 & 1.1194 & 121 & 2.281 & 1.1271 & 0.2535 \\
\hline 9 Professional trips & 116 & 3.612 & 1.2770 & 119 & 4.017 & 1.1788 & $0.0123^{* *}$ \\
\hline 10 Campus conflict & 114 & 3.035 & 1.2546 & 113 & 3.150 & 1.2971 & 0.4966 \\
\hline
\end{tabular}

In Table 15, four practices show significance between men and women. Females show statistically higher practices for:

6. I encourage my students to praise each other for accomplishments.

7. I ask my students to discuss key concepts with others whose backgrounds and viewpoints are different from their own.

8. I create "learning communities," study groups, or teams within my courses.

1. I ask students to tell each other about their interests and backgrounds.

In these four practices, student interaction with one another is accentuated. Female faculty interact with students more than males (Practice One), and then they promote more student-student interaction. Also, male faculty members show means greater than 
2.5 in six areas for this good practice while female faculty members show such means in only two areas.

Table 15

Encourages cooperation among students by gender of faculty member

\begin{tabular}{|l|l|l|l|l|l|l|l|}
\hline Practice Two & $\begin{array}{c}\text { Female } \\
\mathrm{N}\end{array}$ & $\begin{array}{c}\text { Female } \\
\mathrm{M}\end{array}$ & $\begin{array}{c}\text { Female } \\
\mathrm{SD}\end{array}$ & $\begin{array}{c}\text { Male } \\
\mathrm{N}\end{array}$ & $\begin{array}{c}\text { Male } \\
\mathrm{M}\end{array}$ & $\begin{array}{c}\text { Male } \\
\text { SD }\end{array}$ & $\begin{array}{c}\text { t-value } \\
\text { Sign. }\end{array}$ \\
\hline 1 Discuss interests & 122 & 2.197 & 1.0336 & 122 & 2.590 & 1.1190 & $0.0047^{* *}$ \\
\hline 2 Work together & 123 & 1.659 & 0.8080 & 122 & 1.787 & 0.7845 & 0.2084 \\
\hline 3 Do team projects & 122 & 1.918 & 0.9671 & 120 & 2.158 & 1.0042 & 0.0592 \\
\hline 4 Evaluate work & 122 & 2.984 & 1.3236 & 121 & 3.132 & 1.2971 & 0.3775 \\
\hline 5 Explain ideas & 123 & 2.252 & 0.9373 & 121 & 2.314 & 0.9490 & 0.6080 \\
\hline 6 Praise each other & 123 & 2.220 & 1.0444 & 122 & 2.795 & 1.1129 & $0.0000^{* * *}$ \\
\hline 7 Different views & 119 & 2.353 & 1.0217 & 118 & 2.788 & 1.0849 & $0.0017^{* *}$ \\
\hline 8 Study groups & 120 & 2.408 & 1.0166 & 121 & 2.851 & 1.3144 & $0.0038^{* * *}$ \\
\hline 9 Join organization & 118 & 3.110 & 1.2862 & 118 & 3.254 & 1.3636 & 0.4028 \\
\hline 10 Independent grade & 115 & 1.930 & 1.0900 & 117 & 2.231 & 1.5051 & 0.0828 \\
\hline
\end{tabular}

From table 16, there seems to be little difference in how the sexes handled active learning in the classroom. However, in two cases, there are some statistically significant differences, with females showing greater frequency for the practice. The two areas are:

9. My students and I arrange field trips, volunteer activities, or internships related to the course.

1. I ask my students to present their work in class. 
For this practice, the means for both sexes are greater that the median rank (2.5) in four subcategories. These less frequently practiced activities are summarizing the work of different theorists (Item 2), suggesting other activities (Item 8), arranging field trips or other course activities (Item 9), and conducting research projects with students (Item 10).

These data correspond with Practice Two (showing more promotion of studentstudent interaction in the classroom) and Practice One, where females display more likelihood for taking students to professional events in the discipline.

Table 16

Encourages active learning by gender of faculty member

\begin{tabular}{|l|l|l|l|l|l|l|l|}
\hline Practice Three & $\begin{array}{c}\text { Female } \\
\mathrm{N}\end{array}$ & $\begin{array}{c}\text { Female } \\
\mathrm{M}\end{array}$ & $\begin{array}{c}\text { Female } \\
\mathrm{SD}\end{array}$ & $\begin{array}{c}\text { Male } \\
\mathrm{N}\end{array}$ & $\begin{array}{c}\text { Male } \\
\mathrm{M}\end{array}$ & $\begin{array}{c}\text { Male } \\
\text { SD }\end{array}$ & $\begin{array}{c}\text { t-value } \\
\text { Sign. }\end{array}$ \\
\hline 1 Present work & 121 & 2.306 & 1.0476 & 121 & 2.579 & 0.9377 & $0.0339^{*}$ \\
\hline 2 Different works & 118 & 2.797 & 1.1440 & 118 & 2.746 & 1.2756 & 0.7475 \\
\hline 3 Outside relevance & 120 & 1.908 & 0.8599 & 121 & 1.992 & 0.9617 & 0.4785 \\
\hline 4 Research studies & 118 & 2.331 & 1.1251 & 120 & 2.600 & 1.1257 & 0.0660 \\
\hline 5 Challenge ideas & 120 & 2.058 & 0.8916 & 120 & 2.033 & 1.0202 & 0.8400 \\
\hline 6 Real-life issues & 120 & 1.583 & 0.6809 & 121 & 1.595 & 0.7591 & 0.8998 \\
\hline 7 Role-playing & 122 & 2.180 & 1.2333 & 121 & 2.380 & 1.2862 & 0.2176 \\
\hline 8 Suggest activities & 120 & 2.725 & 1.1665 & 119 & 2.840 & 1.1716 & 0.4465 \\
\hline 9 Course trips & 116 & 3.284 & 1.3175 & 118 & 3.771 & 1.2838 & $0.0046^{* *}$ \\
\hline 10 Research Projects & 117 & 3.376 & 1.3047 & 119 & 3.672 & 1.2697 & 0.0785 \\
\hline
\end{tabular}


In only two cases do females show significantly more use for practice four. See

Table 17. These significant areas are:

6. I give my students written comments on their strengths and weaknesses on exams and papers.

8. I ask students to keep logs and records of their progress.

Interestingly, both males and females show lower instances of practicing

subcategories seven to ten. Means for both sexes are greater that 2.5 or the midway point for using pre-tests for beginning the course (item 7), asking students to keep logs and journals (item 8), discussing the results of final exams (item 9), or for calling/writing notes to students who miss class (item 10). Again, females interact more with students.

Table 17

Gives prompt feedback by gender of the faculty member

\begin{tabular}{|l|l|l|l|l|l|l|l|}
\hline Practice Four & $\begin{array}{c}\text { Female } \\
\mathrm{N}\end{array}$ & $\begin{array}{c}\text { Female } \\
\mathrm{M}\end{array}$ & $\begin{array}{c}\text { Female } \\
\text { SD }\end{array}$ & $\begin{array}{c}\text { Male } \\
\mathrm{N}\end{array}$ & $\begin{array}{c}\text { Male } \\
\mathrm{M}\end{array}$ & $\begin{array}{c}\text { Male } \\
\text { SD }\end{array}$ & $\begin{array}{c}\text { t-value } \\
\text { Sign. }\end{array}$ \\
\hline 2 Immediate results & 122 & 1.451 & 0.6815 & 121 & 1.587 & 0.9718 & 0.2085 \\
\hline 3 Return in week & 121 & 1.314 & 0.6080 & 121 & 1.215 & 0.5509 & 0.1841 \\
\hline 4 Evaluate in detail & 120 & 1.617 & 0.7580 & 121 & 1.570 & 0.6433 & 0.6089 \\
\hline 5 Conferences & 119 & 2.017 & 0.9913 & 120 & 2.275 & 1.1149 & 0.0597 \\
\hline 6 Written comments & 122 & 1.557 & 0.8533 & 120 & 1.975 & 1.0164 & $0.0006^{* * *}$ \\
\hline 7 Pre-tests & 118 & 3.220 & 1.3278 & 121 & 3.380 & 1.4563 & 0.3760 \\
\hline 8 Logs and records & 120 & 2.700 & 1.4118 & 119 & 3.227 & 1.4048 & $0.0042^{* *}$ \\
\hline 9 Final results & 117 & 3.077 & 1.3655 & 119 & 3.269 & 1.3448 & 0.2777 \\
\hline 10 Notes if absent & 119 & 2.958 & 1.2171 & 121 & 3.174 & 1.1524 & 0.1603 \\
\hline
\end{tabular}


Table 18 shows data for practice five. In three of ten practices, the females show significantly more frequency of using these practices:

10. If students miss class, I require them to make up lost work.

2. I clearly communicate to my students the minimum amount of time they should spend preparing for class.

7. I explain to my student the consequences of non-attendance.

In this good practice, two of the differences concern communication (Items 2 and

7). For this study, females consistently show more interactions with students, both in conversation and by written work. The most significant item here seems to be an accountability and procedural issue about missed work (item 10). One interesting aspect is seen in Table 18; both sexes employ all of these practices routinely.

Table 18

Emphasizes time on task by gender of the faculty member

\begin{tabular}{|l|l|l|l|l|l|l|l|}
\hline Practice Five & $\begin{array}{c}\text { Female } \\
\mathrm{N}\end{array}$ & $\begin{array}{c}\text { Female } \\
\mathrm{M}\end{array}$ & $\begin{array}{c}\text { Female } \\
\text { SD }\end{array}$ & $\begin{array}{c}\text { Male } \\
\mathrm{N}\end{array}$ & $\begin{array}{c}\text { Male } \\
\mathrm{M}\end{array}$ & $\begin{array}{c}\text { Male } \\
\text { SD }\end{array}$ & $\begin{array}{c}\text { t-value } \\
\text { Sign. }\end{array}$ \\
\hline 2 Time to spend & 120 & 1.150 & 0.3586 & 121 & 1.223 & 0.4741 & 0.1779 \\
\hline 3 Amount of time & 118 & 1.678 & 0.8360 & 120 & 1.733 & 0.8172 & 0.6059 \\
\hline 4 Challenging goals & 119 & 1.782 & 0.8147 & 120 & 1.900 & 0.7713 & 0.2495 \\
\hline 5 Rehearse for class & 116 & 2.060 & 1.0977 & 110 & 2.364 & 1.3114 & 0.0615 \\
\hline 6 Emphasis-work & 119 & 1.454 & 0.6858 & 120 & 1.542 & 0.7875 & 0.3584 \\
\hline 7 Non-attendance & 120 & 1.223 & 0.5142 & 120 & 1.425 & 0.8165 & $0.0307 *$ \\
\hline 8 Full-time study & 117 & 1.795 & 0.9873 & 119 & 2.092 & 1.3529 & 0.0551 \\
\hline 9 Meet if behind & 118 & 2.068 & 0.9760 & 120 & 2.292 & 1.1106 & 0.0998 \\
\hline 10 Make-up work & 120 & 1.558 & 0.7864 & 119 & 2.008 & 1.2656 & $0.0011^{* * *}$ \\
\hline
\end{tabular}


See Table 19 for significant differences for good practice six. These include:

2. I emphasize the importance of holding high expectations for academics.

7. I encourage students to write a lot.

4. I help students set challenging goals for their own learning.

As seen in Table 19, here again, these three significant subcategories suggest communication issues. Female faculty display more interchange with students (Items 7 and 4) and more communication with students (Item 4). Data between the good practices of student-faculty contact (Practice One) and cooperation among students (Practice Two) are consistent. Means in this table also show that both of the sexes reported consistently frequent practice for communication of high expectations in the classroom.

Table 19

Communicates high expectations by gender of the faculty member

\begin{tabular}{|l|l|l|l|l|l|l|l|}
\hline Practice Six & $\begin{array}{c}\text { Female } \\
\mathrm{N}\end{array}$ & $\begin{array}{c}\text { Female } \\
\mathrm{M}\end{array}$ & $\begin{array}{c}\text { Female } \\
\text { SD }\end{array}$ & $\begin{array}{c}\text { Male } \\
\mathrm{N}\end{array}$ & $\begin{array}{c}\text { Male } \\
\mathrm{M}\end{array}$ & $\begin{array}{c}\text { Male } \\
\text { SD }\end{array}$ & $\begin{array}{c}\text { t-value } \\
\text { Sign. }\end{array}$ \\
\hline 1 Give expectations & 119 & 1.244 & 0.4688 & 121 & 1.339 & 0.5561 & 0.1529 \\
\hline 2 Set high standards & 119 & 1.176 & 0.4248 & 121 & 1.413 & 0.6667 & $0.0011^{* * *}$ \\
\hline 3 Oral/written goals & 120 & 1.150 & 0.3586 & 121 & 1.174 & 0.5112 & 0.6790 \\
\hline 4 Set goals & 117 & 1.650 & 0.6736 & 119 & 1.849 & 0.8401 & $0.0455^{*}$ \\
\hline 5 Incomplete work & 120 & 1.325 & 0.5821 & 121 & 1.360 & 0.7101 & 0.5101 \\
\hline 6 Extra tasks & 118 & 2.051 & 0.9594 & 118 & 2.280 & 1.0930 & 0.0888 \\
\hline 7 Writing & 120 & 1.950 & 0.9688 & 117 & 2.308 & 1.1631 & $0.0108^{* *}$ \\
\hline 8 Note excellence & 119 & 1.908 & 0.9112 & 121 & 2.157 & 1.1329 & 0.0612 \\
\hline 9 Revisions & 120 & 1.450 & 0.6718 & 119 & 1.613 & 0.8245 & 0.0945 \\
\hline 10 Progress in class & 120 & 1.575 & 0.6438 & 121 & 1.686 & 0.7420 & 0.2162 \\
\hline
\end{tabular}


Data in Table 20 shows statistical difference in only two practices and in both cases, it is the female who practices the task more often than does the male faculty member. Significance is seen in:

10. I try to find out about my students' learning styles, interests, and backgrounds at the beginning of the course.

6. I integrate new knowledge about women and other under-represented populations into my courses.

In this good practice again, females try to understand more about their students by learning about interests and backgrounds and learning styles and also by using information about under-represented groups. Reporting these two practices more frequently suggest that females are more aware of differences among students. In this practice, both sexes show lower means (greater than 2.5) for providing independent studies (Item 7), for developing alternative learning modules (Item 8), and for encouraging students to design their own majors (Item 9). 
Table 20

Respects diverse talents and ways of learning by gender of faculty member

\begin{tabular}{|l|l|l|l|l|l|l|l|}
\hline Practice Seven & $\begin{array}{c}\text { Female } \\
\mathrm{N}\end{array}$ & $\begin{array}{c}\text { Female } \\
\mathrm{M}\end{array}$ & $\begin{array}{c}\text { Female } \\
\text { SD }\end{array}$ & $\begin{array}{c}\text { Male } \\
\mathrm{N}\end{array}$ & $\begin{array}{c}\text { Male } \\
\mathrm{M}\end{array}$ & $\begin{array}{c}\text { Male } \\
\text { SD }\end{array}$ & $\begin{array}{c}\text { t-value } \\
\text { Sign. }\end{array}$ \\
\hline 1 Speak up & 122 & 1.197 & 0.4571 & 121 & 1.248 & 0.4879 & 0.3994 \\
\hline 2 Do not embarrass & 121 & 1.413 & 0.7924 & 119 & 1.605 & 0.8755 & 0.0766 \\
\hline 3 Diverse methods & 122 & 1.582 & 0.7697 & 121 & 1.760 & 0.7306 & 0.0651 \\
\hline 4 Backgrounds & 121 & 2.033 & 1.0641 & 113 & 2.283 & 1.1218 & 0.0819 \\
\hline 5 Extra help & 120 & 2.050 & 0.9061 & 120 & 2.242 & 1.1000 & 0.1421 \\
\hline 6 Minority data & 120 & 2.358 & 1.0831 & 112 & 2.723 & 1.4532 & $0.0322^{*}$ \\
\hline 7 Independent work & 118 & 2.949 & 1.3195 & 117 & 2.880 & 1.3593 & 0.6942 \\
\hline 8 Alternatives used & 120 & 3.175 & 1.3760 & 118 & 3.203 & 1.4055 & 0.8750 \\
\hline 9 Own majors & 112 & 3.607 & 1.3712 & 108 & 3.417 & 1.4347 & 0.3155 \\
\hline 10 Students' interest & 121 & 1.835 & 0.8977 & 120 & 2.192 & 1.1398 & $0.0075^{* *}$ \\
\hline
\end{tabular}

\section{B. Differences by years of experience:}

In order to calculate years of experience in undergraduate teaching, data from the faculty profile were totaled, using university and community college and four-year college teaching years.

Data relative to years of experience will be reported as: 0-6 years of UG experience-number $(\mathrm{N})$, mean (M), Standard Deviation (SD) $>6$ years of UG experience- number $(\mathrm{N})$, mean $(\mathrm{M})$, Standard Deviation (SD) $\mathrm{t}$-value shown after the row Significance levels- $.05^{*}, .01^{* *}$, and $.001^{* * *}$ 
Table 21 shows that two subcategories for Practice One have significant differences between faculty based on experience levels. In both cases, it is the older, more experienced faculty members who show the greater frequency for the practice. The two significant areas are:

10. Whenever there is a conflict on campus involving students, I try to help in its resolution.

5. I work with student affairs staff on issues related to student extracurricular life and life outside of school

Both categories of faculty show low frequencies of practice (means greater than 2.5) for attending events sponsored by students (Item 4), working with student affairs staff on extracurricular student issues (Item 5), taking students on professional trips (Item 9), and helping to resolve campus conflicts (Item 10). However, even with low frequency of practice, experienced instructors are more likely to work with student affairs staff on extracurricular life or on campus conflicts. 
Table 21

Encourages student-faculty contact by years of experience of faculty

\begin{tabular}{|c|c|c|c|c|c|c|c|}
\hline Practice One & $\begin{array}{c}(0-6) \\
N\end{array}$ & $\begin{array}{c}(0-6) \\
M\end{array}$ & $\begin{array}{c}(0-6) \\
\text { SD }\end{array}$ & $\begin{array}{r}(>6) \\
N\end{array}$ & $\begin{array}{c}(>6) \\
M\end{array}$ & $\begin{array}{l}(>6) \\
\text { SD }\end{array}$ & $\begin{array}{l}\text { t-value } \\
\text { Sign. }\end{array}$ \\
\hline 1 Career advice & 82 & 2.171 & 0.8735 & 162 & 1.944 & 0.9533 & 0.0736 \\
\hline 2 Office visits & 67 & 2.552 & 1.1142 & 152 & 2.263 & 1.2826 & 0.1128 \\
\hline 3 Share experiences & 83 & 1.723 & 0.8449 & 163 & 1.736 & 0.8011 & 0.9039 \\
\hline 4 Attend events & 81 & 3.099 & 1.1415 & 160 & 2.894 & 1.1468 & 0.1911 \\
\hline 5 Student issues & 75 & 3.787 & 1.1419 & 158 & 3.430 & 1.2552 & $0.0392 *$ \\
\hline 6 Know by name & 84 & 1.667 & 1.0097 & 161 & 1.826 & 0.8116 & 0.1820 \\
\hline 7 Different cultures & 80 & 2.338 & 1.0970 & 154 & 2.240 & 1.3866 & 0.5867 \\
\hline 8 Mentor & 82 & 2.244 & 1.0848 & 160 & 2.175 & 1.2025 & 0.6636 \\
\hline 9 Professional trips & 77 & 4.026 & 1.2213 & 158 & 3.715 & 1.2667 & 0.0762 \\
\hline 10 Campus conflict & 74 & 3.446 & 1.2436 & 153 & 2.922 & 1.2729 & $0.0039 * *$ \\
\hline
\end{tabular}

For Practice Two, encourages cooperation among students, not one of the ten subquestions show any significant difference in means, with both categories of faculty demonstrating the practice with similar frequencies. Apparently teaching experience plays little to no part in how often instructors encourage students to cooperate.

As seen in Table 22, five subcategories for Practice Three, encourages active learning, yield significant differences for faculty by years of experience. Those with greater than six years of experience use five practices more than their less experienced colleagues. The practices are: 
4. I ask my students to undertake research or independent study.

6. I give my students concrete, real-life situations to analyze.

5. I encourage students to challenge my ideas, ideas of other students, or those presented in readings or course materials.

8. I encourage students to suggest new readings, research projects, field trips, or other course activities.

2. I ask my students to summarize similarities and differences among different theorists, research findings, or artistic works.

Also seen in Table 22, the experienced faculty members promote more ways to get students involved in the classroom, and many of the significant practices reported in this section should become more comfortable after years of teaching. However, both groups of faculty show low regular practice (means greater that 2.5) for four teaching techniques. These are: summarizing differences and similarities with different theorists and works (Item 2), having students suggest readings or other course activities (Item 8), arranging field trips and other course activities (Item 9), and carrying out research projects with students (Item 10). These areas of lower participation reflect additions and experimentation with the course content and a flexibility to allow students to facilitate the direction of the class. 
Table 22

Encourages active learning by years of experience of faculty

\begin{tabular}{|l|l|l|l|l|l|l|l|}
\hline Practice Three & $\begin{array}{c}(0-6) \\
\mathrm{N}\end{array}$ & $\begin{array}{c}(0-6) \\
\mathrm{M}\end{array}$ & $\begin{array}{c}(0-6) \\
\text { SD }\end{array}$ & $\begin{array}{c}(>6) \\
\mathrm{N}\end{array}$ & $\begin{array}{c}(>6) \\
\mathrm{M}\end{array}$ & $\begin{array}{l}(>6) \\
\text { SD }\end{array}$ & $\begin{array}{l}\text { t-value } \\
\text { Sign. }\end{array}$ \\
\hline 1 Present work & 81 & 2.506 & 0.9518 & 161 & 2.410 & 1.0969 & 0.5024 \\
\hline 2 Different works & 78 & 2.987 & 1.2240 & 158 & 2.665 & 1.1565 & $0.0497^{*}$ \\
\hline 3 Outside relevance & 81 & 2.062 & 0.8944 & 160 & 1.894 & 0.9400 & 0.1849 \\
\hline 4 Research studies & 80 & 2.763 & 1.0411 & 158 & 2.316 & 1.2452 & $0.0067^{* *}$ \\
\hline 5 Challenge ideas & 82 & 2.268 & 0.8896 & 158 & 1.930 & 1.0429 & $0.0136^{* *}$ \\
\hline 6 Real-life issues & 81 & 1.765 & 0.7093 & 160 & 1.500 & 0.7119 & $0.0069^{* *}$ \\
\hline 7 Role-playing & 82 & 2.366 & 1.2967 & 161 & 2.236 & 1.1917 & 0.4369 \\
\hline 8 Suggest activities & 80 & 3.038 & 1.1023 & 159 & 2.654 & 1.2573 & $0.0220^{*}$ \\
\hline 9 Course trips & 76 & 3.750 & 1.3128 & 158 & 3.424 & 1.3178 & 0.0781 \\
\hline 10 Research Projects & 78 & 3.731 & 1.3177 & 158 & 3.424 & 1.2239 & 0.0794 \\
\hline
\end{tabular}

In Practice Four, giving prompt feedback, and Practice Five, encouraging time on task, there are no significant differences in the frequency of practice between newer and more experienced faculty members.

For Practice Six (see Table 23), communicates high expectations, older, more experienced faculty members practice four of the subcategories more frequently, and these are:

7. I encourage students to write a lot.

10. I periodically discuss how well we are doing during the course of the semester.

9. I revise my courses.

5. I explain to students what will happen if they do not complete their work on time. 
The verbs "encourage," "discuss," and "explain" indicate communication and interaction between the faculty and the students. Results for this study show that more experienced faculty communicate more frequently with the students. They also are more likely to revise the course than were the less experienced faculty members. In addition, both categories of faculty performed very well in communicating high expectations to the students. All means in this practice are less than 2.5.

Table 23

Communicates high expectations by years of experience of faculty

\begin{tabular}{|l|l|l|l|l|l|l|l|}
\hline Practice Six & $\begin{array}{c}(0-6) \\
\mathrm{N}\end{array}$ & $\begin{array}{c}(0-6) \\
\mathrm{M}\end{array}$ & $\begin{array}{c}(0-6) \\
\mathrm{SD}\end{array}$ & $\begin{array}{c}(>6) \\
\mathrm{N}\end{array}$ & $\begin{array}{c}(>6) \\
\mathrm{M}\end{array}$ & $\begin{array}{l}(>6) \\
\text { SD }\end{array}$ & $\begin{array}{l}\text { t-value } \\
\text { Sign. }\end{array}$ \\
\hline 1 Give expectations & 80 & 1.338 & 0.5105 & 160 & 1.269 & 0.5264 & 0.3368 \\
\hline 2 Set high standards & 80 & 1.300 & 0.5784 & 160 & 1.294 & 0.5603 & 0.9359 \\
\hline 3 Oral/written goals & 81 & 1.198 & 0.3694 & 160 & 1.144 & 0.5572 & 0.4337 \\
\hline 4 Set goals & 79 & 1.797 & 0.7730 & 157 & 1.726 & 0.7575 & 0.4986 \\
\hline 5 Incomplete work & 81 & 1.494 & 0.5627 & 160 & 1.281 & 0.7766 & $0.0304^{*}$ \\
\hline 6 Extra tasks & 77 & 2.312 & 0.9466 & 159 & 2.094 & 1.1839 & 0.1617 \\
\hline 7 Writing & 79 & 2.392 & 0.9610 & 158 & 1.994 & 1.2549 & $0.0143^{* *}$ \\
\hline 8 Note excellence & 80 & 2.075 & 1.0400 & 160 & 2.013 & 1.0284 & 0.6590 \\
\hline 9 Revisions & 79 & 1.709 & 0.6219 & 160 & 1.444 & 0.9494 & $0.0261^{*}$ \\
\hline 10 Progress in class & 81 & 1.790 & 0.6616 & 160 & 1.550 & 0.7368 & $0.0146^{* *}$ \\
\hline
\end{tabular}

For Practice Seven, there are three areas in which the more experienced group show highly significant differences (see Table 24). More experienced faculty show much more frequency of practice in these areas: 
9. I encourage students to design their own majors if their interests warrant it.

8. I have developed mastery learning, learning contracts, or computer alternatives for my courses.

7. I make explicit provisions for students who wish to carry out independent studies in my own courses or as separate courses.

Experienced faculty are more likely to allow students to design their own majors, develop alternative learning procedures, and carry out independent studies (Items 9, 8, and 7). The significance level for these three practices was high at .001 , but the overall means for both groups in these three practices indicate mostly occasional or rare practice. Overall, experienced instructors show more innovation and flexibility in the classroom.

Table 24

Respects diverse talents and ways of learning by experience of faculty

\begin{tabular}{|l|l|l|l|l|l|l|l|}
\hline Practice Seven & $\begin{array}{c}(0-6) \\
\mathrm{N}\end{array}$ & $\begin{array}{c}(0-6) \\
\mathrm{M}\end{array}$ & $\begin{array}{c}(0-6) \\
\text { SD }\end{array}$ & $\begin{array}{c}(>6) \\
\mathrm{N}\end{array}$ & $\begin{array}{c}(>6) \\
\mathrm{M}\end{array}$ & $\begin{array}{l}(>6) \\
\text { SD }\end{array}$ & $\begin{array}{l}\text { t-value } \\
\text { Sign. }\end{array}$ \\
\hline 1 Speak up & 82 & 1.256 & 0.4489 & 161 & 1.205 & 0.5167 & 0.4475 \\
\hline 2 Do not embarrass & 81 & 1.543 & 0.8334 & 159 & 1.491 & 0.8522 & 0.6491 \\
\hline 3 Diverse methods & 82 & 1.732 & 0.7293 & 161 & 1.640 & 0.8020 & 0.3852 \\
\hline 4 Backgrounds & 78 & 2.321 & 1.0843 & 156 & 2.071 & 1.1107 & 0.1039 \\
\hline 5 Extra help & 79 & 2.316 & 0.9597 & 161 & 2.062 & 1.0924 & 0.0802 \\
\hline 6 Minority data & 77 & 2.740 & 1.2742 & 155 & 2.432 & 1.2917 & 0.0878 \\
\hline 7 Independent work & 78 & 3.346 & 1.2783 & 157 & 2.701 & 1.3563 & $0.0006^{* * *}$ \\
\hline 8 Alternatives used & 79 & 3.658 & 1.3564 & 159 & 2.956 & 1.3386 & $0.0002^{* * *}$ \\
\hline 9 Own majors & 70 & 4.029 & 1.3898 & 150 & 3.273 & 1.2963 & $0.0001^{* * *}$ \\
\hline 10 Students' interest & 81 & 2.012 & 1.0217 & 160 & 2.013 & 1.0781 & 0.9991 \\
\hline
\end{tabular}




\section{Differences in Practice by Academic Area}

For this analysis, the mean for each particular good practice is calculated by academic area. Rows One through Seven indicate the department area with all ten subcategories averaged to derive the overall mean in that department, with a table for each practice. Tables 25-31 show the data.

See Table 25 with means for good practice one. The allied health department's mean for practice one is significantly lower (indicating more practice) than those for five of the six other academic areas. Only the education area shows no significant difference in regards to this good practice.

Table 25

Best use of practice one (encourages student-faculty contact) by academic department

\begin{tabular}{|l|l|l|l|l|}
\hline Department & $\mathrm{N}$ & $\mathrm{M}$ & $\mathrm{SD}$ & t-value/sign. \\
\hline Allied Health & 38 & 2.1643 & 1.0825 & \\
\hline Business & 42 & 2.4579 & 1.3425 & $0.0009 * * *$ \\
\hline Education & 9 & 2.4023 & 1.2980 & 0.1168 \\
\hline Humanities & 56 & 2.6818 & 1.2926 & $0.0000^{* * *}$ \\
\hline Social Sciences & 38 & 2.7537 & 1.3392 & $0.0000^{* * *}$ \\
\hline Technology & 20 & 2.4949 & 1.4160 & $0.0048 * *$ \\
\hline Math/Science & 49 & 2.7597 & 1.3110 & $0.0000 * * *$ \\
\hline
\end{tabular}

For encouraging cooperation among students, the education department shows best practice. Only the technology department does not show significantly lower use for this good teaching practice. The areas of business, humanities, social science, and 
math/science show significantly less usage for encouraging cooperative work among their students. Allied health shows better implementation for this practice than most of the other departments, but is still significantly different from the education department. These results are noted in Table 26 .

Table 26

Best use of practice two (encourages cooperation among students) by academic department

\begin{tabular}{|l|l|l|l|l|}
\hline Department & $\mathrm{N}$ & $\mathrm{M}$ & $\mathrm{SD}$ & t-value/sign. \\
\hline Education & 9 & 1.9778 & 1.1320 & \\
\hline Allied Health & 38 & 2.2722 & 1.0410 & $0.0270 *$ \\
\hline Business & 42 & 2.4866 & 1.2104 & $0.0002 * * *$ \\
\hline Humanities & 56 & 2.4033 & 1.2450 & $0.0014 * * *$ \\
\hline Social Sciences & 38 & 2.6199 & 1.1853 & $0.0000^{* * *}$ \\
\hline Technology & 20 & 2.2412 & 1.2481 & 0.0777 \\
\hline Math/Science & 49 & 2.6383 & 1.2099 & $0.0000 * * *$ \\
\hline
\end{tabular}

For the use of active learning in the classroom, Table 27 gives the means and the education area shows best practice with both humanities and technology having no significant differences from the education area. The areas of allied health, business, social sciences, and math/science show much lower frequency for this practice. The academic area of math/science shows the least practice and the significance is high. The overall mean for math/science in promoting active learning is rated as occasionally. 
Table 27

Best use of practice three (encourages active learning) by academic department

\begin{tabular}{|l|l|l|l|l|}
\hline Department & $\mathrm{N}$ & $\mathrm{M}$ & $\mathrm{SD}$ & t-value/sign. \\
\hline Education & 9 & 2.1222 & 1.1100 & \\
\hline Allied Health & 38 & 2.4629 & 1.0693 & $0.0099 * *$ \\
\hline Business & 42 & 2.5239 & 1.2782 & $0.0031 * *$ \\
\hline Humanities & 56 & 2.3084 & 1.2589 & 0.1507 \\
\hline Social Sciences & 38 & 2.5462 & 1.1915 & $0.0018^{* *}$ \\
\hline Technology & 20 & 2.2750 & 1.3030 & 0.3062 \\
\hline Math/Science & 49 & 3.0436 & 1.3026 & $0.0000 * * *$ \\
\hline
\end{tabular}

Table 28 shows the means and significant differences for the practice relative to giving prompt feedback. For this good practice, the departments in general show good frequency for use. For departments of business, humanities, social sciences, technology, and math/science, the significance level is very strong relative to the allied health area. Only the education department shows no significant difference in this good practice. However, all means for all departments average to 2.5 or below. 
Table 28

Best use of practice four (gives prompt feedback) by academic department

\begin{tabular}{|l|l|l|l|l|}
\hline Department & $\mathrm{N}$ & $\mathrm{M}$ & $\mathrm{SD}$ & t-value/sign. \\
\hline Allied Health & 38 & 1.8761 & 1.1551 & \\
\hline Business & 42 & 2.2721 & 1.3473 & $0.0000^{* * *}$ \\
\hline Education & 9 & 2.0562 & 1.1810 & 0.1995 \\
\hline Humanities & 56 & 2.2377 & 1.3101 & $0.0000^{* * *}$ \\
\hline Social Sciences & 38 & 2.5217 & 1.3577 & $0.0000^{* * *}$ \\
\hline Technology & 20 & 2.3600 & 1.4037 & $0.0000^{* * *}$ \\
\hline Math/Science & 49 & 2.1838 & 1.2573 & $0.0003 * * *$ \\
\hline
\end{tabular}

Table 29 gives the means and significance levels for practice five, emphasis for time on task. All the departments show excellent usage and all means are less that 2.0 (coded often). Even departments showing less frequent usage than does the allied health area still have low means and therefore frequent practice. 
Table 29

Best use of practice five (emphasizes time on task) by academic department

\begin{tabular}{|l|l|l|l|l|}
\hline Department & $\mathrm{N}$ & $\mathrm{M}$ & $\mathrm{SD}$ & t-value/sign. \\
\hline Allied Health & 38 & 1.5605 & 0.7911 & \\
\hline Business & 42 & 1.7396 & 1.0103 & $0.0068 * *$ \\
\hline Education & 9 & 1.6222 & 0.7581 & 0.4972 \\
\hline Humanities & 56 & 1.7218 & 0.9811 & $0.0073 * *$ \\
\hline Social Sciences & 38 & 1.9646 & 1.0597 & $0.0000^{* * *}$ \\
\hline Technology & 20 & 1.6950 & 0.9199 & 0.0852 \\
\hline Math/Science & 49 & 1.6925 & 0.9607 & $0.0346 *$ \\
\hline
\end{tabular}

For practice six (data in Table 30), all departments show means of less than 2.0 and therefore good frequency for telling students about high expectations. Nevertheless, four departments lag behind the others in this good practice; these departments are business, social sciences, technology, and math/science. Allied health shows best usage for this good undergraduate practice. 
Table 30

Best use of practice six (communicates high expectations) by academic department

\begin{tabular}{|l|l|l|l|l|}
\hline Department & $\mathrm{N}$ & $\mathrm{M}$ & $\mathrm{SD}$ & $\mathrm{t}$-value/sign. \\
\hline Allied Health & 38 & 1.4882 & 0.6848 & \\
\hline Business & 42 & 1.7034 & 0.9020 & $0.0002 * * *$ \\
\hline Education & 9 & 1.5222 & 0.6907 & 0.6782 \\
\hline Humanities & 56 & 1.5009 & 0.8146 & 0.8031 \\
\hline Social Sciences & 38 & 1.6877 & 0.8492 & $0.0007 * * *$ \\
\hline Technology & 20 & 1.9000 & 1.0657 & $0.0000^{* * *}$ \\
\hline Math/Science & 49 & 1.6962 & 0.8761 & $0.0002 * * *$ \\
\hline
\end{tabular}

See data in Table 31 for practice seven relative to respecting diverse talents and ways of learning. All departments show means less that 2.5 and therefore very often and often are the most common responses. Only math/science shows significantly lower usage than the department showing best mean, which is the education department. 
Table 31

Best use of practice seven (respects diverse talents/ways of learning by academic department)

\begin{tabular}{|l|l|l|l|l|}
\hline Department & $\mathrm{N}$ & $\mathrm{M}$ & $\mathrm{SD}$ & t-value/sign. \\
\hline Education & 9 & 2.0889 & 1.2420 & \\
\hline Allied Health & 38 & 2.1490 & 1.2227 & 0.6820 \\
\hline Business & 42 & 2.2155 & 1.2556 & 0.3847 \\
\hline Humanities & 56 & 2.2155 & 1.3390 & 0.3777 \\
\hline Social Sciences & 38 & 2.3314 & 1.3168 & 0.1060 \\
\hline Technology & 20 & 2.2677 & 1.3720 & 0.2748 \\
\hline Math/Science & 49 & 2.4776 & 1.3011 & $0.0082 * *$ \\
\hline
\end{tabular}

After perusing all tables relative to good practices, two academic areas show the most consistent and most frequent use of the Seven Practices. The allied health area shows best practice in Area One (encourages student-faculty contact), Area Four (gives prompt feedback), Area Five (emphasizes time on task), and Area Six (communicates high expectations). The education area shows most usage for Area Two (encourages cooperation among students), Area Three (encourages active learning) and Area Seven (respects diverse talents and ways of learning).

Overall, the academic area reporting the least routine use for the Seven Principles is the math/science with all seven practices showing significant differences from academic areas showing best practice. Following closely with six areas being 
significantly different are business and social sciences. Humanities and technology show fewer differences.

\section{Research Question 9}

9. Qualitatively, what developmental interventions and policies do colleges use to help their adjunct faculty?

On the faculty profile at the end of the survey instrument, the respondents were asked to check the developmental interventions offered by their college. From all respondents, the interventions were tallied and the results summarized in Table 5. All workshops and training sessions also had rankings from those who attended. For the technology workshop, $56.35 \%$ of all faculty attended. More than three-quarters of the attendees rated the workshop between average and very good. Over $40 \%$ of the total faculty attended workshops on syllabus development, orientation to college, and advising. In all three cases, the workshops were rated between average and very good. Two other workshops had fewer respondents as attendees; these were mentoring (19.84\%) and a teaching workshop (34.13\%). All the workshops received average to very good ratings. Therefore, faculty seemed to appreciate the training sessions; however, the attendance rate was often low. It must be noted that these training sessions were for all faculty and not strictly for adjuncts.

In addition, review of the raw data shows that some full-time and part-time faculty from all three community colleges did attend all workshops except one. No parttime faculty at the Mid-Central college listed attendance at the workshop on writing exams. This workshop may have been offered for full-time faculty only or occurred at some inconvenient time for adjuncts. 
Another area of the survey may be used to investigate this research question. Table 32 gives a summary of the reasons for teaching at community colleges. These summaries come from the profile question stated as "list your top 3 positive features" to enhance classroom teaching practice.

The most frequently mentioned positive feature of classroom teaching for fulltime faculty is a comment about being able to use various teaching methods. Many of these specific methods (such as one-on-one contact, collaborative exercises, hands-on work and demonstrations, and Internet work) are noted in the surveys. This tally for classroom procedures seems to correspond well with data from research question two and three where the full-time faculty showed more frequency for cooperation among students and more techniques for active learning. Thus, it seems that these three colleges allow autonomy in the classroom and encourage or permit instructors to experiment with a number of teaching options. Of the part-time instructors, 77 of the 126 also mention the use of good teaching practices. Table 32 shows the tallied positive comments for fulltime and part-time faculty and four policies show high number of responses for both categories of faculty. Being allowed to use good teaching practices, using relevance or experience in the classroom, having good supplies for teaching, and maintaining good student relations are very important to both sets of faculty.

Several items important to full-time faculty are not even mentioned buy parttimers. Possibly the adjunct faculty sense no control over class size or physical facilities, assistants or staff help, and conducting trips off campus. 
Table 32

Positive Reasons for Teaching at Community Colleges

\begin{tabular}{|l|c|c|}
\hline Categories of responses & Full Time & Part Time \\
\hline 1. Allows variety of teaching methods & & \\
\hline 2. Have or use good teaching practices & & \\
\hline 3. Have experience and knowledge of subject, relevant & 45 & 77 \\
\hline 4. Perks of the college & 35 & 41 \\
\hline 5. Good supplies for the classroom & 4 & \\
\hline 6. Have good rapport with students & 25 & 21 \\
\hline 7. Administrative backing & 15 & 13 \\
\hline 8. Small class size & 12 & \\
\hline 9. Good physical facilities & 5 & \\
\hline 10. Use of industry standards in the classroom & 4 & \\
\hline 11. Good help-assistants, staff, technicians & 4 & \\
\hline 12. Can conduct fieldtrips and demonstrations & 3 & \\
\hline 13. Good students, interested in the classes & 3 & \\
\hline
\end{tabular}

${ }^{1}$ Variety of teaching methods-lot of student interaction, cooperative work, one-on-one type of instruction, flexibility, collaboration

${ }^{2}$ Good teaching-enthusiastic, give personal attention, caring, non-judgmental, available to students, concerned for students

${ }^{3}$ Perks of college-good computers, good printers, good coping, Internet access, Powerpoint usage, A-V department, graphing calculators for math classes, grading technology, faculty development money

${ }^{4}$ Supplies for classroom-computers in some labs, good overheads, video discs, good audio-visual supplies for class

${ }^{5}$ Physical facilities-blackboards, good lighting, nice rooms

\section{Research Question 10}

10. What positive features and strategies should be added to support their adjunct and full-time faculty (to improve the quality of instruction)?

By examining common issues seen in the major concerns charts for both categories of faculty, some stresses and problems are evident. The question on the 
faculty profile is stated as, "Please describe your top 3 concerns which affect your ability to provide excellent instruction at your college?" See Table 33 and Table 34 for major concerns of teaching from community college faculty.

Stresses common to the respondents are apparent when both tables are interpreted in tandem. Both faculty groups are concerned about the poor skill levels of students, heavy loads and little time for self or the class, and equipment (old or "out-of-date") or other facilities. For both categories of faculty, the skill level of the students and the size of the teaching load and its required time commitment receive the highest frequency of comment.

Table 33

Major concerns from full-time faculty

\begin{tabular}{|c|c|c|c|c|c|}
\hline Categories of responses & $\mathrm{CCMC}$ & CCNR & CCSR & Tally & Rank \\
\hline 1. Poor student skills ${ }^{1}$ & 11 & 17 & 13 & 41 & 1 \\
\hline 2. Heavy loads, no time ${ }^{2}$ & 16 & 6 & 4 & 26 & 2.5 \\
\hline 3. Money $^{3}$ & 9 & 7 & 10 & 26 & 2.5 \\
\hline 4. Poor administration & 8 & 5 & 4 & 17 & 4 \\
\hline 5. Physical facilities ${ }^{4}$ & 8 & 0 & 7 & 15 & 5 \\
\hline 6. Poor technical help & 5 & 3 & 6 & 14 & 6 \\
\hline 7. No release time, little development time ${ }^{5}$ & 3 & 6 & 3 & 12 & 7 \\
\hline 8. Too much paperwork, too many meetings ${ }^{6}$ & 0 & 0 & 6 & 6 & 8 \\
\hline 9. Old equipment & 5 & 0 & 0 & 5 & 9 \\
\hline 10. Poor telecom system & 0 & 4 & 0 & 4 & 10 \\
\hline
\end{tabular}

${ }^{1}$ Poor study skills, poor time management, poor math and reading skills, low preparation for college, low interest and poor attendance, poor note taking and poor test taking skills, lazy outside of class

${ }^{2}$ Stress, no time to do a good job, no privacy with so many students, very large classes, lots of papers and preparations and classes to teach

${ }^{3}$ Money low for both salaries and for new or better equipment

${ }^{4}$ Physical problems, small lab size, temperature in classrooms (both heat and A.C.), bad desks, sound problems in some rooms, few copiers use, no space 
${ }^{5}$ No release time to develop new courses or new curricula, no time to practice, little development money, not time for innovations, no time to develop self

${ }^{6}$ Paperwork, too much paperwork not related to teaching, too many meetings, too much time spent on things with no relationship to teaching

Table 34

Major concerns from part-time faculty

\begin{tabular}{|l|l|l|l|l|l|}
\hline Categories of responses & CCMC & CCNR & CCSR & Tally & Rank \\
\hline 1. Classes too big & 7 & 6 & 8 & 21 & 1 \\
\hline 2. Skill level of student - poor & 3 & 7 & 10 & 20 & 2 \\
\hline 3. Poor communication with FT faculty & 6 & 5 & 3 & 14 & 3.5 \\
\hline 4. Old equipment, out of date & 11 & 3 & 0 & 14 & 3.5 \\
\hline 5. Poor technical help, no technology to use & 4 & 4 & 3 & 11 & 5 \\
\hline 6. Low money & 5 & 5 & 0 & 10 & 6 \\
\hline 7. Need help, some workshops to train & 4 & 0 & 3 & 7 & 7 \\
\hline 8. Poor administration & 3 & 0 & 0 & 3 & 8 \\
\hline
\end{tabular}

If the major challenges emphasized by all faculty are addressed, then all faculty could improve quality of instruction. The biggest challenge facing all faculty seems to be institutional support: physical (class size), economic (more money for salaries and for equipment), orientation and mentoring of part-time and new faculty, better distribution of faculty loads, training (workshops and guidance in technology use), and attitudinal (an acceptance and appreciation for work done). Probably the best way to state the challenges is to say that all faculty need to feel a sense of support from the college.

\section{Summary of the Results}

In the statistical comparison for frequency of usage of the Seven Principles of Good Practice in Undergraduate Education, four major findings are seen from the data. 
These four findings are seen from Research Questions One-Seven and from Research Question Eight. The fifth finding comes from the faculty profile sections of the study. See Table 35 for a summary of the statistical data.

Statistical findings

1. For the first seven research questions, full-time faculty report significantly higher rates of practice for all Seven Principles than do part-time faculty. The full-time faculty show higher rates of practice in 27 of the 70 total subcategories. Practice One (encouraging student-faculty contact) and Practice Five (emphasizing time on task) exhibit the most significant differences. Thus the full-time faculty display more quality of instruction as measured by their responses to this survey. In no area do part-time faculty report significantly higher rates for the good practice.

2. Relative to variations by gender of the faculty member, there are differences in each of the seven good practices. In every case, females demonstrate more frequency of the good practices than do male faculty. However, there are fewer differences in the subcategories between males and females than there are between full and part-time faculty. In 19 of the 70 subcategories, differences by gender are significant. Practice two, cooperation among students, shows the most differences with a total of four.

3. The significant differences (in good practices) are fewer between newer and more experienced faculty. Significant differences occur in only four of the good practices. These are Practice One (faculty-student contact), Practice Three (encouraging active learning), Practice Six (communicating expectations), and Practice Seven (respecting diverse talents and learning). In each case, the more mature, experienced faculty show the greatest frequency of good practice. In 14 of 70 subcategories, there are differences. 
Of the three factors, type of faculty (part-time versus full-time), gender of instructor (male versus female) and experience level of faculty members, the differences based on experience occur in fewer instances.

4. Two academic areas exhibit more frequent use of the seven good practices: allied health and education. Due to the strict requirements for clinical laboratory sizes and student to instructor ratio in the allied health courses, it seems rather commonsense that this area should show best practice in encouraging student-faculty contact, giving prompt feedback, emphasizing time on task, and communicating high expectations. In these areas, small groups of students meet weekly or bi-weekly with the clinical instructor. The education area should model good classroom interactions with students. Therefore, this area should show the most expertise for supporting all students. It seems reasonable that the education department should be excellent in practices of encouraging cooperation among students, encouraging active learning, and respecting diverse talents and ways of learning. This study shows these strengths.

To sum up the first Seven Research Questions and Research Question Eight, the most effective faculty tend to be full-time, female, and more experienced. The most effective overall teaching, as reported in this study, occurs in the allied health and education areas. 
Table 35

Summary of significant results (by subcategory of good practice)

\begin{tabular}{|c|c|c|c|c|}
\hline Seven Practices & $\begin{array}{l}\text { Status FT/PT } \\
\text { (significant in } \\
\text { subcategory) }\end{array}$ & $\begin{array}{l}\text { Gender } \\
\text { (significant in }^{2} \\
\text { subcategory) }\end{array}$ & $\begin{array}{l}\text { Experience level } \\
\text { (significant in } \\
\text { subcategory) }\end{array}$ & $\begin{array}{l}\text { Discipline } \\
\text { of highest } \\
\text { usage }\end{array}$ \\
\hline $\begin{array}{l}\# 1 \\
\text { faculty-student } \\
\text { contact }\end{array}$ & $\begin{array}{l}1,2 \\
4,5 \\
8,9,10 \\
\end{array}$ & $\begin{array}{l}4, \\
6, \\
9 \\
\end{array}$ & $\begin{array}{l}5 \\
10\end{array}$ & $\begin{array}{l}\text { Allied } \\
\text { Health }\end{array}$ \\
\hline $\begin{array}{l}\# 2 \\
\text { cooperation } \\
\text { among students }\end{array}$ & $\begin{array}{l}3 \\
8 \\
9\end{array}$ & $\begin{array}{l}1,6 \\
7,8\end{array}$ & None & Education \\
\hline $\begin{array}{l}\text { \#3 } \\
\text { encourages } \\
\text { active learning }\end{array}$ & $\begin{array}{l}5 \\
8, \\
9\end{array}$ & $\begin{array}{l}1 \\
9\end{array}$ & $\begin{array}{l}2,4 \\
5,6 \\
8\end{array}$ & Education \\
\hline $\begin{array}{l}\# 4 \\
\text { gives prompt } \\
\text { feedback }\end{array}$ & $\begin{array}{l}5 \\
7\end{array}$ & $\begin{array}{l}6 \\
8\end{array}$ & None & $\begin{array}{l}\text { Allied } \\
\text { Health }\end{array}$ \\
\hline $\begin{array}{l}\text { \# } 5 \\
\text { emphasizes } \\
\text { time on task } \\
\end{array}$ & $\begin{array}{l}2,3 \\
6,7 \\
8,9 \\
\end{array}$ & $\begin{array}{l}2, \\
7, \\
10\end{array}$ & None & $\begin{array}{l}\text { Allied } \\
\text { Health }\end{array}$ \\
\hline $\begin{array}{l}\text { \#6 } \\
\text { communicate } \\
\text { expectations }\end{array}$ & $\begin{array}{l}1,5 \\
9\end{array}$ & $\begin{array}{l}2, \\
4, \\
7\end{array}$ & $\begin{array}{l}5,7 \\
9,10\end{array}$ & $\begin{array}{l}\text { Allied } \\
\text { Health }\end{array}$ \\
\hline $\begin{array}{l}\text { \# } 7 \\
\text { respects diverse } \\
\text { talents/learning }\end{array}$ & $\begin{array}{l}1, \\
6, \\
8\end{array}$ & $\begin{array}{l}6, \\
10\end{array}$ & $\begin{array}{l}7 \\
8, \\
9\end{array}$ & Education \\
\hline
\end{tabular}

FT=full-time faculty $\quad$ PT=part-time faculty

${ }^{1}$ Full-time faculty showed significance over part-time faculty

${ }^{2}$ Female faculty showed significance over male faculty, regardless of status

${ }^{3}$ Experienced faculty showed significance over less experienced faculty

Research Questions Nine and Ten yield no statistical findings and display more general results. The last finding is of a general nature.

5. General Findings

Research Question Nine shows that faculty members appreciate the autonomy to use a variety of teaching methods and experiment with what they consider to be good teaching practices. Many also find that the college environment allows them to use a 
number of technical tools in their teaching. Faculty do appreciate training and workshops, but often do not attend such training.

Research Question Ten indicates that faculty desire more time for themselves and for class preparation, development opportunities, and money for salary and equipment. They want help with some physical problems and would appreciate more technical assistance. The main concerns of all faculty are the skill level of the students, lack of time for course preparation and self, and physical concerns (building and equipment). 


\section{CHAPTER 5: CONCLUSIONS AND RECOMMENDATIONS}

The purpose of this chapter is to analyze the significant results of this study and develop conclusions. In addition to reviewing the problem statement, this chapter will discuss the results and their implications for practice in community colleges and recommend areas for future study.

\section{Problem}

State legislatures are under stress from reduced tax revenues and increasing cost of state services, and one result is that fiscal support for higher education has been dropping precipitously for several years. As noted in Chapter 1, one way for colleges to cut costs is to increase the use of adjunct faculty who teach courses both on-campus and at off-campus locations. In fact, a recent report from the National Center for Education Statistics (2000) shows that part-time faculty now represent $62 \%$ of the teaching faculty for community colleges (up from $40 \%$ just a few years ago). The ratio of adjunct faculty has been increasing for several years, and this trend is expected to continue.

Institutions should foster best practices in teaching, provide materials and other resources as needed, and offer workshops or training useful to the non-permanent faculty. This study examines the frequency for using the Seven Principles of Good Practice in Undergraduate Education for all faculty members at three Appalachian community colleges. By examining the results, the faculty and administrators can then design workshops and programs to help employees in doing a better job. The faculty profile part of the study investigates what services and support services are available and which ones are used. This study suggests what other services are needed. Faculty in certain 
academic areas may have stronger teaching practices. These academic areas may be able to serve as support and offer training for all faculty of the community colleges.

\section{Summary of Results}

For research questions One to Seven and research Question Eight, the subcategories showing significance are noted in Table 35. There does not appear to be a consistent practice which is seen as significant among all three variables (status of faculty, gender of faculty, and experience level of faculty) or even between two areas. Therefore, if there is correlation between certain groups and certain practices, it is not detected here. However, four statistically significant findings are seen.

Finding 1: Full-time compared to part-time faculty engaged more frequently in good practices; these differences occurred in 27 of the 70 subcategories of good practice. These differences occurred in all seven practices, with Practice One (encouraging student-faculty contact) and Practice Five (emphasizes time on task) being the two showing the most significant differences. Full-time faculty appear to know the students better, interact more with students, communicate more with students, are more creative and flexible in course content and procedures, and spend more time on task.

One conclusion is that a faculty office is essential for good practices in college teaching. Differences between the two faculty categories appear to center around the presence or absence of an office; only one-third of the adjuncts have an office to use. If part-time instructors have no private meeting place, students will not drop by for mentoring, for career advice, or for sharing extracurricular interests. Likewise, the faculty member will not know the students as well and will show less interest in student activities outside of class. 
In the areas of time on task and communicating high expectations, most of the subcategories underscore intercourse with words such as "communicate clearly", "make clear", "underscore", "explain", "tell”, and "meet with students". It may be noted that two-thirds of the adjunct faculty have no office hours per week and only $33 \%$ report having an office. With large classes, which typically meet only once a week, it would be most difficult to give personal direction to every student in class.

Another indication is that all faculty need some flexibility and motivation to experiment with new content and procedures in class. In good practice seven, respecting diverse talents and ways of learning, many adjuncts may not know about the learning alternatives available by the college. Most student assistances (readers, writing help, special machines, special practice laboratories) are available only during regular office hours.

This study is consistent with the work of Leslie. Leslie states that matters relating to quality have little to do with actual instruction and more to do with the support for learning, to provide a time and place for students to learn. Leslie (1998, p. 85) states, "I would argue that the quality issues are less about what occurs in the classroom and more about the general environment that supports learning." For more effective change in how all faculty practice the Seven Good Principles, there needs to be more support for faculty. Both faculty groups show concern for student skill levels; this suggests that placement levels need to be practiced when registering students for classes. Other areas mentioned frequently include low financial support, poor administration, heavy workload and time commitment, older equipment, and need for more technical assistance. The physical support measures needed by the full-time faculty are of a different character than 
is the support for the part-time faculty. For adjunct faculty, there is serious need for office, email, and computer support.

Finding 2: In the area of gender differences, the females showed significantly more frequency of use in the seven good practices than did the males. In the 19 of 70 subcategories showing differences, one trend is evident. Female faculty spent more time getting to know the students; female faculty attended more student directed events; women took students on more trips and promoted more student interactions; and females communicated more with students, both orally and in written form.

The conclusion from finding two is that all female faculty communicate better with students that do males. This study corresponds extremely well with the work of Belenky at al. (1997, p.45) which reports that women "valuing connection and intimacy are much more likely to be inclusionary, finding 'they' and 'we' to be intertwined and interdependent." This intertwining among females seems to carry over into their teaching practices. If females prefer more interaction and inclusion, they may assume their students prefer more interactions and consequently female instructors promote more cooperation and sharing among their students.

Belenky et al. (p. 113) classify women's method of growing in knowledge through telling stories and getting to know each other as "connected knowing," and the knowledge comes from sharing experiences. Female faculty members are promoting this way of learning. This study supports the Belenky concept about females' learning behaviors, and also this appears to be the female teaching behavior.

Belenky et al. (p. 121) note that "many females take naturally to connected learning" and that "connected knowing builds on the subjectivists' conviction that the 
most trustworthy knowledge comes from personal experience." With written comments and journal writing, the female faculty and students actively learn from each other. Likewise, because of the improved communication, female faculty members may feel more comfortable discussing consequences for work which is not completed. It is also possible that discussing unpleasant or negative consequences would be easier for students who are "connected" with the instructor.

Finding 3: Relating to experience time in higher education, the more experienced faculty members displayed more frequent use of good practices. This occurred in 14 of the 70 subcategories and seemed to revolve around better communication with students, more innovation and experimentation in class, and more involvement in extracurricular student events and life outside the classroom. More experienced faculty have a lot of practical ideas which should be passed on to the less experienced staff. One explanation for this better performance by the more mature faculty may relate to the practice of awarding tenure in these three community colleges. The more experienced faculty would have been evaluated for teaching effectiveness before they were awarded tenure; thus the more experienced faculty should use many good practices in their classrooms.

Biles and Tuckman (1986, p. 132) make an extensive list of recommendations for the orientation and development of part-time faculty. In general, the conclusion they offer is good communication which "can pay off in terms of future dividends in the form of increased productivity, greater employee satisfaction on the job, and greater institutional identification and loyalty." This study indicates a great deal of this communication needs to be between the less experienced group and the more mature faculty if quality of teaching is the area slated for improvement. 
Finding 4 - When the data are examined for differences between teaching areas, two disciplines (allied health and education ) are shown to be frequent users of the seven principles. In conclusion, these two departments should be used to help promote better teaching practices for the whole college. There appear to be a number of reasons why these departments show good practices.

\section{A. Allied Health area:}

a. For Practice One, encourages student-faculty contact, nursing clinical groups (usually seven or eight students per faculty member) are very small, and the faculty and the students are in a position to become intimately acquainted. Other allied health groups also show limited enrollments and low faculty-student ratio. In addition, these groups have performance standards for licensing which necessitates much faculty-student interaction.

b. For Practice Four, gives prompt feedback, allied health laboratories and clinical days require performance of medical procedures, and these are evaluated immediately. Few other areas evaluate so many procedures almost instantaneously.

c. For Practice Five, emphasizes time on task, allied health departments set up laboratory times for practice and the students have so much time to master the procedures. The instructors would constantly point out time lines and upcoming practice times.

d. For Practice Six, communicates high expectations, there appear to be two reasons for effectiveness in this category. First, a huge majority of allied health faculty are females, and females communicate more with their students. Secondly, 
allied health faculty meet with their students in clinical laboratories every week and discuss upcoming procedures.

\section{B. Education Department}

a. For Practice Two, encourages cooperation among students, results seem clear for the education department's effectiveness. Working with younger children means keeping the children involved, having children learn to take turns and share and work together with every child included. Education departments need to model this behavior, and this study shows that they do encourage more interaction among their own students.

b. For Practice Three, encourages active learning, the education department is most effective. Young children will not sit still and take notes in lecture. Here the two education departments are practicing good procedures to use in class.

c. Practice Seven, respects diverse talents and ways of learning, is a necessary attitude for teachers of young children. Teachers need to find the positive aspects of all children and work to embellish and promote them. These education departments seem to illustrate through example.

Caveat for Assumptions from This Department

These means are averaged from only nine respondents and must therefore be viewed with scrutiny. I suspect the data may be accurate for larger numbers, but all these colleges either have no education department or have very small ones.

A conclusion from this finding is that community college policies need to emulate some of the conditions required in these departments. 
Finding 5: The two general research questions (Nine and Ten) showed that these community colleges offer a number of developmental interventions and procedures to help all faculty. Three subcategories reflect the overall results seen in this study.

a. Colleges' interventions and policies to assist faculty: These colleges conducted numerous workshops and training sessions over the years. However, only the workshop on technology was attended by at least $50 \%$ of all faculty with other workshops showing much lower attendance rates. Somewhat paradoxically, participants reported profit from the workshops, if they attended. Perhaps instead of optional attendance, these colleges need to require a certain number of workshops every year. Some policy requiring continual training and innovation in the classroom seems to be implemented for faculty at these three community colleges.

The data correspond well with the work of Richardson (1992, p.33) who notes that "faculty development for adjunct faculty will not succeed unless sufficient incentives, particularly money and status are provided." With the three community colleges in this study, it seems that the statement may also apply to full-time faculty. b. Positive features and strategies to improve instruction: These faculty members reported an appreciation for being allowed to show flexible in the classroom, with relevancy, cooperation, student interaction, collaboration, and one-on-one teaching mentioned. Workshops in these areas should be added so that all faculty can continue to be innovative and creative.

c. Major challenges to be addressed: A number of concerns also showed up in the study, with much of the anxiety relating to the skill levels of the students and the heavy loads and little time available for faculty. A number of faculty also desired some assistance in 
areas relating to facilities (space and seating, temperature controls, or connections for more technology), technical help, money for salary, and more classroom technology. In addition, poor administration was mentioned as a concern for all three schools. Surveys mentioning "poor administration" included no qualifying information, and most probably referred to the chairpersons, since many adjunct faculty communicate with only the chair. Improvement in administrative practices was needed in these three colleges.

Tucker (1993, p. 3) indicates some attributes of a healthy department; these are faculty and staff who are motivated, productive, appreciated, secure in their jobs, and work well together. Tucker (p. 9) states that "healthy departments support faculty who make efforts to expand their own interests and skills" by "judicious use of rewards and sanctions." Since money in most colleges is scarce, these reward incentives are not likely to be available; rewards need to motivational or garnering prestige, not cash.

Another area receiving negative comments by the part-time faculty is communication. Tucker (p.9) again gives some guidance by stating, "healthy departments support an open and collegial atmosphere. People communicate freely with one another, and information is shared in appropriate ways." At these three community colleges, the two categories of faculty do not routinely meet in a departmental setting. For reasons relating to support and communication, the adjunct faculty may sense that administration is poor.

These contemporary concerns corresponded well with the seminal work of Herzberg et al. (1957, p.39) who labeled workplace aspects of the job as "intrinsic aspects of the job, supervision, working conditions, and wages." These four job aspects were reported most often in his identification of major on-the-job factors of employment. 
This study shows concerns in six areas common for both groups of faculty. These concerns are intrinsic student quality, heavy loads, insufficient money (salary and equipment), poor administration, and equipment problems (technical needs or older technology). The types of students and their preparation level and the size of classes or the workload can be called intrinsic aspects of the job, and they are a consequence of teaching in a community college. The other factors are extrinsic, related to either the institution (administration) or determined by outside controls (finances from the state legislature, for determination of salary and equipment money). From this study, college administration may conclude that many factors of employment do not change and consistent problems of the job still need to be addressed.

Colleges and universities are under increasing financial stress and need to make sure they hire the most effective faculty members possible. For administrators to recruit and hire the best faculty available, they need to consider the background of the faculty member. Likewise, looking at the results of this study should show administrators how to assist the faculty members to become better and to stay productive.

Balch (1999) also notes that colleges need to implement procedures to support part-time faculty and find areas for increased participation. Adjunct faculty need to be included in the life of the college or university and be offered facilities so they may perform at high levels of efficiency. From Table 8, the physical support areas offered by these community colleges are greatly reduced for their part-time staff, and these colleges need to improve their developmental procedures.

\section{Recommendations for Administrators (department chairs)}

1. Recommendations relative to part-time faculty 
a. Some suggestions are adjunct group offices, shared phones, computer access to the college from home, and perhaps promoting office hours on Saturdays. Department chairs need to establish such offices with the chief academic officer supporting this effort.

b. Many workshops are poorly attended due to the time of their presentation. More variety in the times for workshops could include weekend or night offerings so the adjunct faculty may attend. For example, one community college recently offered its adjunct orientation and workshops on consecutive evenings in the summer; one evening could be allotted for each campus.

c. Students could communicate more with adjunct faculty if all faculty had office hours. The institution could pay a small stipend for office hours of part-time faculty and could suggest that faculty use office hours for tutoring or mentoring students. Perhaps the requirement of two office hours per week could be written into the contacts for all part-time faculty. Then all faculty members could get to know at least some of their students better. This recommendation can only occur if the college's president and dean make it mandatory and alter the contracts.

d. Other helpful supports would be required tours of the college for all new employees and new students. These could be offered on a variety of occasions, weekends, evenings, and during the day.

e. The media center could offer more workshops on using new technology and audiovisual equipment, with some of these sessions at night and on weekends. Another suggestion is that the software associated with these technical sessions be installed immediately on the faculty member's computer when the training is completed. 
f. A secretarial pool with extended hours could help the adjunct faculty. Secretaries could rotate through the extended hours and therefore offer better assistance to the adjunct faculty members. The dean's office may need to coordinate this service.

g. Assigning lockers for adjunct's books, coats, and papers would be helpful. This should be college-wide in all buildings and on all campuses.

h. Administrators need to disperse with the "hired hand" attitude toward part-time faculty. These faculty should be allowed more autonomy for revising, experimenting, and adding projects for their courses. As long as course objectives are met, more freedom should be emphasized and perhaps even demanded, especially in those courses where the content changes rapidly. Chairs need to see that this attitude prevails throughout the entire faculty, full-time and part-time.

2. Recommendations relative to full-time faculty

a. Less experienced faculty should be paired with more experienced faculty in a mentoring or demonstration type of system, until the new faculty becomes more knowledgeable about the college and teaching.

b. New employees should be required to attend several workshops about teaching practices, technology use, and the in-class teaching techniques. Immediately after the training, any software should be installed onto the faculty member's computer.

c. Departments should have standard syllabi and expectations for all faculty in the area.

3. Recommendations relative to gender

Females show much more interaction with students, and most of it revolves around more communication. Relative to the differences in performance between the sexes of faculty members, males appear to be under more stress to keep an attitude of 
distance toward their students. Some men report that this separation or stand-off attitude occurs due to sexual harassment training, and this is unlikely to change soon.

a. Workshops could be held to assist all faculty in being more empathetic and still maintaining a professional demeanor. Workshops on civility and respectful attitudes and behavior in the classroom can be offered for both students and faculty.

b. The administrative staff should make absolutely sure that they model the correct behavior at all times. Most administrators in colleges are male, and one stress factor mentioned at all three community colleges is poor administration (by full-time faculty). Only one college's part-time faculty mention poor administration. The chief academic officer's office needs to promote accountability of conduct at every level.

c. Workshops could be offered for all faculty members to illustrate ways for appreciating and incorporating diverse leaning styles into courses. Colleges need a Center for Teaching Innovation, which can offer a variety of workshops, but at times most convenient to all part-time and full-time faculty. The times and dates need to vary so that high numbers of faculty and staff may attend.

4. Recommendations for experienced level of faculty

In 14 of 70 subcategories, experienced faculty showed more use of good practices than did the less matured faculty. Also Table 7 showed that only $19.84 \%$ of the faculty had any sort of mentoring. Of the respondents, 202 had no mentor for assistance. This study shows that the older, more experienced faculty members have a lot of good practices to pass on. The administration should expect every department or area to use this expertise. 
a. Every new faculty member should be assigned a mentor. One conclusion from this study is that a colleague or mentoring system would help less experienced faculty. Older faculty report better communication patterns with students and are better at getting students involved with learning. They also seem better in incorporating diverse learning methods and can greatly assist the less experienced staff.

b. Mentors should volunteer and mentoring should not be mandatory. Some faculty members may not wish to be mentors and would resent being forced to take on that role. However, many more mature instructors would willingly accept the position of advisor to a younger or less experienced instructor.

c. A small stipend or reward should be included to assist the mentor. This might be a certificate to place in the personnel file or could be a small gift given to every mentor after encouragement is offered for one year.

d. Several departments currently require mentoring of their new employees; these successful programs should be studied and expanded.

e. More mature faculty showed more innovation for introducing new content or new ways of teaching the subject (learning contracts and alternative methods of delivery). These faculty could invite newer instructors into their classroom so they could model innovations. "Brainstorm" sessions with older faculty might be well received by newer members in the college.

5. Recommendations between Academic Areas Two departments or teaching areas display excellent practice for undergraduate 
teaching; these areas are allied health and education. College-wide administration should use this expertise to help other faculty members achieve more effective teaching. There appear to be a number of reasons why these departments show good practices.

a. Administrators should allow the faculty members who are willing to conduct workshops on improving performance in the seven practices. This may be easiest for the education area, but allied health faculty will also have much advice to offer.

b. Much of the success in allied health programs involves more contact between faculty and a small number of students. Perhaps an enrollment cap could be placed on certain classes, especially classes critical for future success in a program.

c. One concern by faculty is the large number of students and no time for development. Administrators could try to equalize the loads of faculty. Instead of some faculty having light loads in all semesters and some faculty having heavy numbers of students, faculty should be expected to have both types of classes. The upper-level, smaller classes should be matched by the faculty teaching some large classes in the general academic core. This recommendation may be very hard to manage for adjunct faculty members; however, all faculty would appreciate some attempt at equity of loads.

6. Recommendations for all faculty

The table on support services (Table 8) points out several ideas for assistance to faculty members. All faculty, part-time or full-time, seem to appreciate workshops if they are well-done and if the time is suitable for the faculty.

a. One option is to use a stipend to encourage all faculty to gain training and expertise. Richardson (1992) offers several ideas (such as test making workshops and using 
video taping of practice lectures) for encouraging more development for all faculty, and the price is most modest.

7. Recommendations for hiring

If there are employment options between hiring a new, inexperienced faculty member and a more experienced instructor, then it seems likely the more mature faculty member would be better in the classroom immediately and would be more useful to the institution if a program needs to be set up immediately. However, with training and mentoring, the newer instructor will develop; the newer instructor might be most desirable if there are more experienced persons around who can nurture this employee along for a few years.

Tucker $(1993$, p. 3) provides some characteristics for healthy employees in departments; these are "motivated, productive, appreciated, secure in their jobs, work well together as a group, and able to reach consensus on issues." He also comments on communication within healthy departments as having "an open and collegial atmosphere." Practically all these recommendations can be condensed into appreciation and inclusion for everyone.

\section{Recommendations for Further Study}

This study involves a very limited number of faculty and only three community colleges in one state. Other states and general areas of the country need to replicate the study. With different demographics for a faculty and different influences due to the area and different arrangements of community colleges structure (such as under a state university or state college), the results might be different. 
Researchers could study frequency of good practices before and after several training sessions and workshops and a mentoring procedure. Perhaps some departments or certain colleges in a state could develop several support systems for the newer faculty and then the good practice inventory of practice could be done for the supported versus the non-supported faculty members.

Another possible study might be to compare faculty between community colleges which are unionized versus those not unionized. Many union contracts require a certain numbers of workshops for faculty each year. This type of study could help determine if workshops really do lead to better teaching practices.

This study looked at broad groupings and some of these sets could be examined more closely. For example, perhaps the results for experienced versus less experienced could be split out into part-time and full-time experienced versus less experienced. Some of the larger categories may need to be broken down in subgroups to elucidate the reasons for some of the overall findings. The data could be dissected more fully and the conclusions would then be more exact in nature.

This inventory is actually part of a series of surveys. There are surveys for the students and for the institution itself. These two surveys could be used also by these three colleges as an addendum to this study. Augmentation to this study would be to use the strong and weak areas of practices seen for these colleges as a method to determine workshops to use at in-service.

Certain departments in this study exhibit these good teaching practices more often that other departments and could assist other departments in developing more knowledge and use of these Seven Good Practices. Other research studies can be used to see if this 
is the case with other colleges' academic areas of Education and Allied Health. It is most unwise to base an assumption upon work from one limited study. Plus all the analysis for the education departments is based on nine responses.

Another research project would be to see how the students of these two academic areas respond to the use of the good practice. It would be interesting to see if the good practices carry over to the students of these academic areas. The Good Practices: Student Inventory is designed to measure student frequencies for using these same good practices.

Another research project could be comparisons between teaching practices using different sized classes to determine the current pressures for increased class size. Is there a maximum size of class for excellent teaching practices before part-time faculty must be hired to help out the full-time cadre? 


\section{References}

Alfred P. Sloan Foundation. (1998). Report of the Sloan conference: Part-time, Adjunct, or temporary faculty: The new majority.

American Association of Community Colleges. (1995-1996). Pocket profile of community colleges: Trends and statistics, 1995-1996.

American Association of University Professors. (1980). The status of part-time faculty. Washington, DC: 00 gopher root: \{aaup.redbook.section1\}. Retrieved July 1, 2001 from source.

Balch, P. (1999). Part-time faculty are here to stay. Planning for Higher Education. Vol. $27,32-41$.

Banachowski, G. (1996). Perspectives and perceptions: A review of the literature on the use of part-time faculty in community colleges. ERIC Document Reproduction Service No. ED 398943.

Belenky,M.F. et al. (1997). Women's ways of knowing: The development of self, voice, and mind (Tenth Anniversary Edition). New York: Basic Books.

Biles, G.E. and H.P. Tuckman. (1986). Part-time faculty personnel management policies. New York: MacMillian Publishing.

Bolge, R.D. (1995). Examination of student learning as a function of instructor status (Full-time versus Part-time) at Mercer County Community College. ERIC Document Reproduction Service No. ED 382241.

Brookfield, S.D. (1986). Understanding and facilitating adult learning. San Francisco: Jossey-Bass. 
Chickering, A, Gamson,Z., and Barsi, L. (1987). Faculty Inventory: Seven principles for good practice in undergraduate education. American Association of Higher Education and the Johnson Foundation: Racine, Wisconsin.

Cohen, A.M. and Brawer, F.B. (1996). The American community college ( $3^{\text {rd }}$ ed.). San Francisco: Jossey-Bass Publishers.

Committee G, American Association of University Professors. (1992). On the status of non-tenure track faculty. Academe, 78(6), 39-45.

Conference on Growing Use of Part-time and Adjunct Faculty. (1998). Statement from the conference on the growing use of part-time and adjunct faculty. Academe 84(1), 54-60.

Conti, G.J. (1990). Identifying your teaching style. In M. Galbraith (ed.), Adult learning methods: A guide to effective teaching. (pp.79-90). Malabar, FL: Kreiger Publishing.

Cruse, D.B. (1987). Student evaluations and the university professor: Caveat Professor. Higher Education 16, 723-737.

Dennison, R.S. and Seyedmonir, M. (1998). Survey construction. In Introduction to educational research class notebook.

Digranes, J.L. and Digranes, S.H. (1995). Current and proposed uses of technology for training part-time faculty. Community College Journal of Research and Practice, 19(2), 161-169.

Farrell, T.J. (1992). How to kill higher education. Academe, 78(6), 30-33.

Foster, D. and E. Foster. (1998). It's a buyer's market: “Disposable professors," grade inflation, and other problems. Academe 84(1), 29-35. 
Friedlander, J. (1980). Instructional practices of part-time faculty. In Micheal Parsons (Ed.), Using part-time faculty effectively. New Directions for Community Colleges, No.30.

Gamson, Z.F. (1991). A brief history of the Seven Principles for Good Practice in Undergraduate Education. New Directions for Teaching and Learning. No. 47, Fall 1991, 5-12.

Gappa, J.M. (1984). Part-time faculty: Higher education at a crossroad. (ASHE-ERIC Higher Education Research Report No. 3, 1984). Washington, DC: ASHE-ERIC.

Gappa, J.M. and Leslie, D.L. (1993). The invisible faculty: Improving the status of parttimers in higher education. San Francisco: Jossey-Bass.

Gardiner. L.E. (1994). Redesigning higher education: Producing dramatic gains in student learning.: Report No. 7. Washington, D. C.: Graduate School of Education and Human Development, The George Washington University.

Haworth, K. (1999). More community colleges push to hire Ph.D’s as professors. Chronicle of Higher Education, 45(18). From Ebsco Host.

Heinrich, V. (1996). Professional development using the Internet. Adult Learning, Jan./Feb., 9-10.

Hernandez, A.E. and Schmidt, S.J. (1995). The role of student, instructor, and administrator perception of effective teaching. Journal of Excellence in College Teaching, 6(3), 85-94.

Herzberg, F. et al. (1957). Job attitudes: Review of research and opinion. Pittsburgh, Penn.: Psychological Service of Pittsburgh.

Issac, S. and Micheal, W.B. (1995). Handbook in research and evaluation. San Diego: 
Educational and Industrial Testing Services.

Klein, W.C., Weisman, D. \& Smith, T.E. (1996). The use of adjunct faculty: An exploratory study of eight social work programs. Journal of Social Work Education, 32 (2), 253-263.

Lawler, P.(1988). The keys to adult learning: Theory and practical strategies. New York: N.Y.

Leatherman, C. (1997). Growing use of part-time professors prompts debate and calls for action. The Chronicle of Higher Education, 44(7), A14-A15.

Leatherman, C. (1997). Heavy reliance of low-paid lecturers said to produce 'faceless departments'. The Chronicle of Higher Education, 43(27), A12-A13.

Leslie, D.W. (1993). The growing use of part-time faculty: Understanding causes and effects. San Francisco: Jossey-Bass.

Leslie, D.W., Kellams, S.E. \& Gunne, G.M. (1982). Part-time faculty in American higher education. New York: Praeger Publishers.

Lundy, K.L. and Warme, B.D. (1990). Gender and career trajectory: the case of part-time faculty. Studies in Higher Education, 15(2), 207-222.

Magner, D. K. (1997). Record number of doctorates awarded in 1997. Chronicle of Higher Education Vol.45, Issue 18. From Ebsco Host.

Mangan, K.S. (1991). Many colleges fill vacancies with part-time professors, citing economy and uncertainty about enrollments. The Chronicle of Higher Education August 7, A9-A10.

McGuire, J. (1993). Part-time faculty: Partners in excellence. Leadership Abstracts. 1-3. (ERIC Document Reproduction Service No. ED 367429. 
Merriam, S.B. (1987). Adult learning and theory building: A review. Adult Education Quarterly 34(4), Summer. 187-198.

Merriam, S.B. (1998). Quantitative Research and Case Study Applications in Education. San Francisco: Jossey-Bass.

National Center for Education Statistics. (1997). [1993 National Study of Postsecondary Faculty (NSOPF-930] Instructional faculty and staff in higher education institutions: Fall 1987 and Fall 1992, NCES 97-470.

National Center for Education Statistics. (2000). [1993 National Study of Postsecondary Faculty (NSOPF-930] Instructional faculty and staff in public 2-year colleges, NCES 2000-192.

O'Banion, T. (1997). A learning college for the 21th century. Phoenix, AZ: The Onyx Press.

Oblinger D.G. and Verville, A. L. (1998). What business wants from higher education. Phoenix, AZ: The Onyx Press.

Poulsen, S.J. (1991). Making the best use of the Seven Principles and the faculty and institutional inventories. New Directions in Teaching and Learning. No 47, Fall 1991, 27-35.

Reichard, G.W. (1998). Part-time faculty in research universities: Problems and prospects. Academe $84(1), 40-43$

Rhoades, G. (1996). Reorganizing the faculty workforce for flexibility: Part-time professional labor. Journal of Higher Education 67(6). 626-659.

Richardson, R.C. (1992). The associate program: Teaching improvement for adjunct faculty. Community College Review 20(1), 29-34. 
Rodabaugh, R.C. and Kravitz, D.A. (1994). Effects of procedural fairness on student judgments of professors. Journal of Excellence in College Teaching. 5(2). 67-83.

Sokal, R.R. and Rohlf, F.J. (1969). of Biometry: The principles and practice statistics in biological research. San Francisco, CAL. W.H. Freeman and Company.

Sorcinelli, M.D. (1991). Research findings on the Seven Principles. New Directions for Teaching and Learning. No. 47, Fall 1991, p. 13-25.

Sutliff, M.A. (1992). A comparison of the perceived teaching effectiveness of full-time faculty, graduate teaching assistants, coaches, and part-time faculty at selected universities in Tennessee. Retrieved October 2, 2000, from OCLC FirstSearch.

Thompson, K. (1992). Recognizing mutual interests: Use of part-time faculty reflects a broader business strategy to minimize pay and maximize control. Academe, 78(6), 22-26.

Tucker, A. (1993). Chairing the academic department: Leadership among peers. Phoenix, AZ: The Onyx Press.

Tuckman, H.P. (1978). Who is part-time in academe? AAUP Bulletin. 64.

Winona State University, The Seven Principles Resource Center. (1989). Seven Principles for Good Practice in Undergraduate Education. Racine, Wisconsin.

Wlodkowski, R.J. (1990). Strategies to enhance adult motivation to learn. In M. Galbraith (Ed.) Adult learning methods: A guide to effective instruction. p.97118 Malabar, FL: Kreiger Publishing. 
Appendix A

Faculty Inventory: Seven Principles of Good Practice in Undergraduate Education \begin{tabular}{llllllllllllllll}
$\mathbf{F}$ & $\mathbf{A}$ & $\mathbf{C}$ & $\mathbf{U}$ & $\mathbf{L}$ & $\mathbf{T}$ & $\mathbf{Y}$ & $\mathbf{I}$ & $\mathbf{N}$ & $\mathbf{V}$ & $\mathbf{E}$ & $\mathbf{N}$ & $\mathbf{T}$ & $\mathbf{O}$ & $\mathbf{R}$ & $\mathbf{Y}$ \\
\hline
\end{tabular}

\section{Good Practice Encourages} Student - Faculty Gonlact

1. I advise my students about career opportunities in their major field.

2. Students drop by my office just to visit.

3. I share my past experiences, attitudes, and values with students.

4. I attend events sponsored by student groups.

5. I work with student affairs staff on issues related to student extracurricular life and life outside of school.

6. I know my students by name by the end of the first two weeks o the term.

7. I make special efforts to be available to students of a culture or race different from my own.

8. I serve as a montor or informal advisor to students.

9. I take students to professional meetings or other events in my field.

10. Whenever there is a conflict on campus involving students, I try to help in its resolution.

As I look at my responses to this section. I would like to work on:

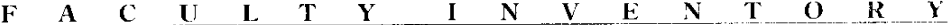

\section{Good Practice Encourages Gooperation Among} Students

1. I ask students to tell each other about their interests and backgrounds.

2. I encourage my students to prepare together for classes or exams.

3. I encourage students to do projects together.

4. I ask my students to evaluate each other's work.

5. I ask my students to explain difficult ideas to each other.

6. I encourage my students 10 praise each other for their accomplishments.

7. I ask my students to discuss key concepts with other student whose backgrounds and viewpoints are different from their own

8. I create "learning communities," study groups, or project teams within my courses.

9. I encourage students to join at least one campus organization.

10. I distribute performance criteria to students so that each person's grade is independent of those achieved by others.

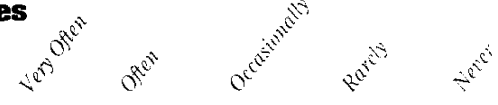

As I look at my responses to this section, I would like to work on 
\begin{tabular}{llllllllllllllll}
$\mathbf{F}$ & $\mathbf{A}$ & $\mathbf{C}$ & $\mathbf{U}$ & $\mathbf{L}$ & $\mathbf{T}$ & $\mathbf{Y}$ & $\mathbf{I}$ & $\mathbf{N}$ & $\mathbf{V}$ & $\mathbf{E}$ & $\mathbf{N}$ & $\mathbf{T}$ & $\mathbf{O}$ & $\mathbf{R}$ & $\mathbf{Y}$ \\
\hline
\end{tabular}

\section{Food Practice Encourages}

1. I ask nyy students 10 present their work to the class.

2. I ask my students to summarize similarities and differences among different theorists, research findings, or artistic works.

3. I ask my students to relate outside events or activities to the subjects covered in my courses.

4. I ask niy students to undertake research or independent study.

5. I encourage students to challenge my ideas, the ideas of other students, or those presented in readings or other course materials.

6. I give my students concrete, real-life situations to analyze.

7. I use simulations, role-playing, or labs in my classes.

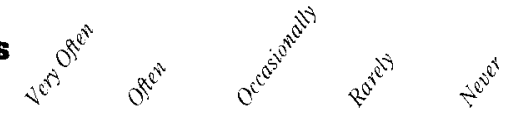

I encourage my students to suggest new readings, research projects, field trips, or other course activities.

9. My students and $I$ arrange field trips, volunteer activities, or internships related to the course.

10. I carry out research projects with my students.
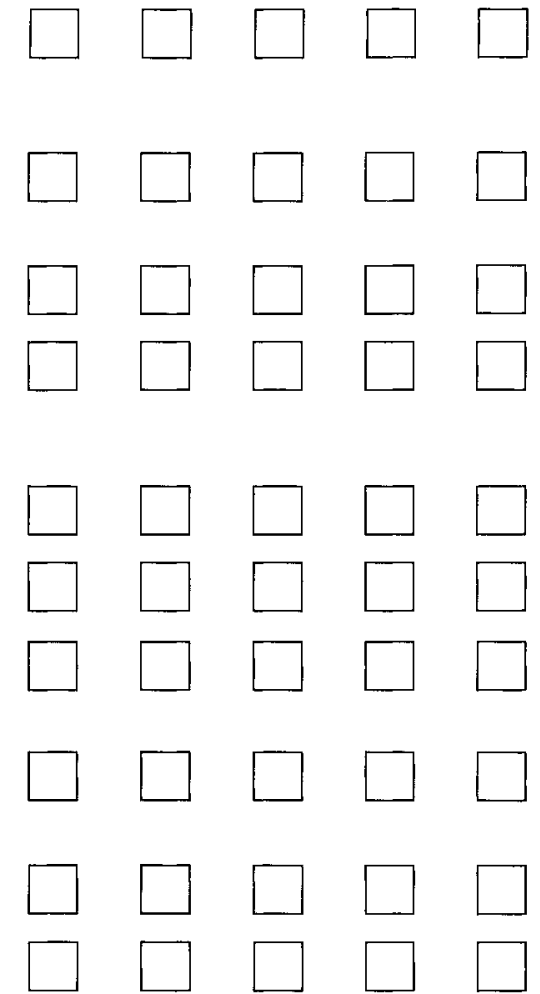

$\begin{array}{llllllllllllllll}\mathbf{F} & \mathbf{A} & \mathbf{C} & \mathbf{U} & \mathrm{L} & \mathrm{T} & \mathrm{Y} & \mathrm{I} & \mathbf{N} & \mathbf{V} & \mathrm{L} & \mathrm{I} & \mathrm{T} & \mathbf{O} & \mathrm{R} & \mathrm{Y}\end{array}$

1. Good Practice Gives Prompt Feedback

I. I give quizzes and homework assignments.

2. I prepare classroom exercises and problems which give students immediate feedback on how well they do.

3. I return examinations and papers within a week.

4. I give students detailed evaluations of their work early in the term.

5. I ask my students to schedule conferences with me to discuss their progress.

I give my students written

comments on their strengths and weaknesses on exams and papers.

7. I give my students a pre-test at the beginning of each course.

8. I ask students to keep logs or records of their progress.

9. I discuss the results of the final examination with my students at the end of the semester.

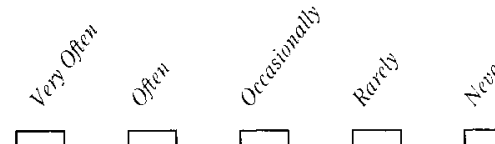

I call or write a note to students who miss classes.
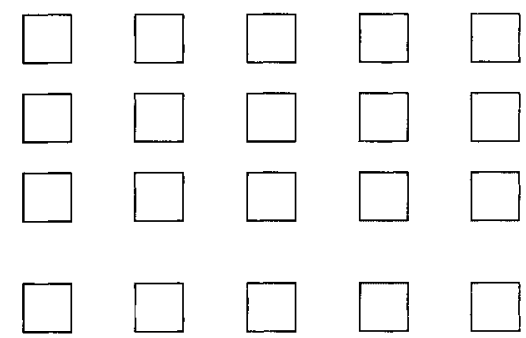

$\square \square \square \square \square$

$\square \square \square \square \square$
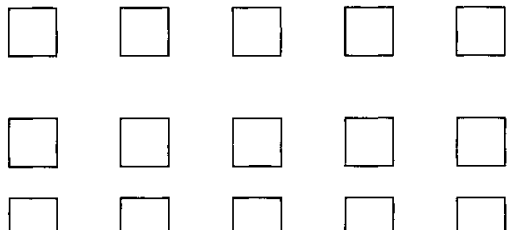

As I look at my responses to this section, I would like to work on: 
\begin{tabular}{llllllllllllllll}
$\mathbf{F}$ & $\mathbf{A}$ & $\mathbf{C}$ & $\mathbf{U}$ & $\mathbf{L}$ & $\mathbf{T}$ & $\mathbf{Y}$ & $\mathrm{I}$ & $\mathbf{N}$ & $\mathrm{V}$ & $\mathrm{E}$ & $\mathrm{N}$ & $\mathbf{T}$ & $\mathbf{O}$ & $\mathbf{R}$ & $\mathrm{Y}$ \\
\hline
\end{tabular}

Cood Practice Emphasizes Time on Task

1. I expect nuy students to complete their assignments promptly.

2. I clearly communicate to my students the minimum amount of time they should spend preparing for classes.

3. I make clear to my students the anoun of time that is required to understand complex material.

4. I help students set challenging goals for their own learning.
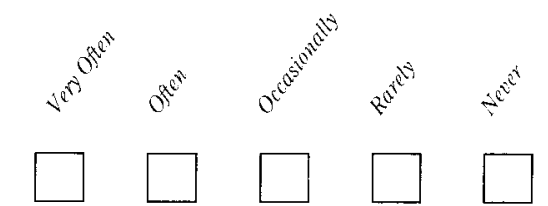

(1)
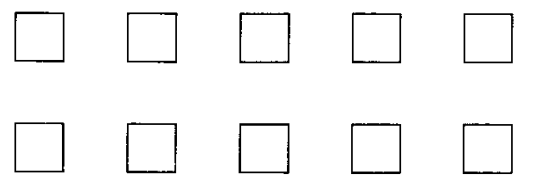

5. When oral reports or class presentations are called for I encourage students to rehearse in advance.

6. I underscore the importance of regular work, steady application, sound self-pacing, and scheduling.

7. I explain to ny students the consequences of non-attendance.

8. I make it clear that full-time study is a full-time job that requires forty or more hours a week.

9. I meet with students who fall behind to discuss their study habits, schedules, and other commitments.

10. If students miss my classes, I require them to make up lost work.

As I look at my responses to this section, I would like to work on: \begin{tabular}{llllllllllllllll} 
F & $A$ & $C$ & U & L & T & Y & I & N & V & E & I & T & O & R & Y \\
\hline
\end{tabular}

B. Bood Practice

Communicates

High Expectations

1. I tell students that I expect them to work hard in my classes.

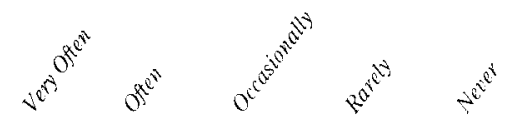

I emphasize the importance of

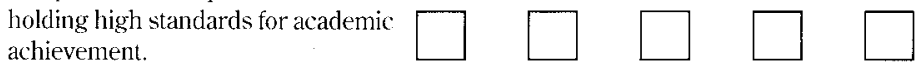

3. I make clear my expectations orally and in writing at the beginning of each course.

4. I help students set challenging goals for their own learning.

5. I explain to students what will happen if they do not complete their work on time.

6. I suggest extra reading or writing tasks.

7. I encourage students to write a lot. 8. I publicly call attention to excellent performance by my students.

9. I revise my courses.

10. I periodically discuss how well we are doing during the course of the scmester.
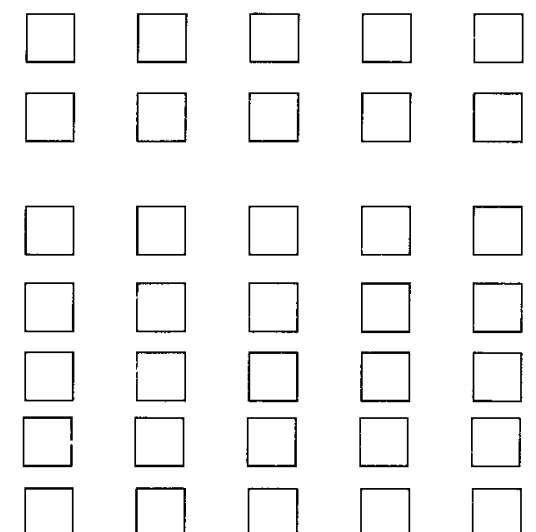

As I look at my responses to this section, I would like to work on: 


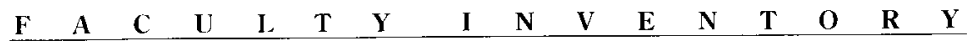

I Good Practice Respects

Diverse Talents and Ways of Learning

1. I encourage students to speak up when they don't understand.

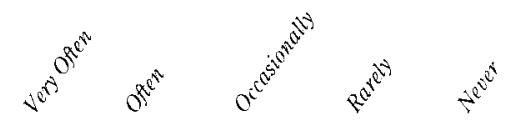

2. I discourage snide remarks, sarcasm, kidding, and other class behaviors that may embarrass students.

3. I use diverse teaching activities to address a broad spectrum of students.

4. I select readings and design activities related to the background of my students.

5. I provide extra material or exercises for students who lack essential background knowledge or skills.

6. I integrate new knowledge about women and other under representated populations into my courses.

7. I make explicit provisions for students who wish to carry out independent studies within my own course or as separate courses.

8. I have developed mastery learning, learning contracts, or computer assisted learning alternatives for my courses.

9. I encourage my students to design their own majors when their interests warrant doing so.

10. I try to find out about my students' learning styles, interests, or backgrounds at the beginning of each course.
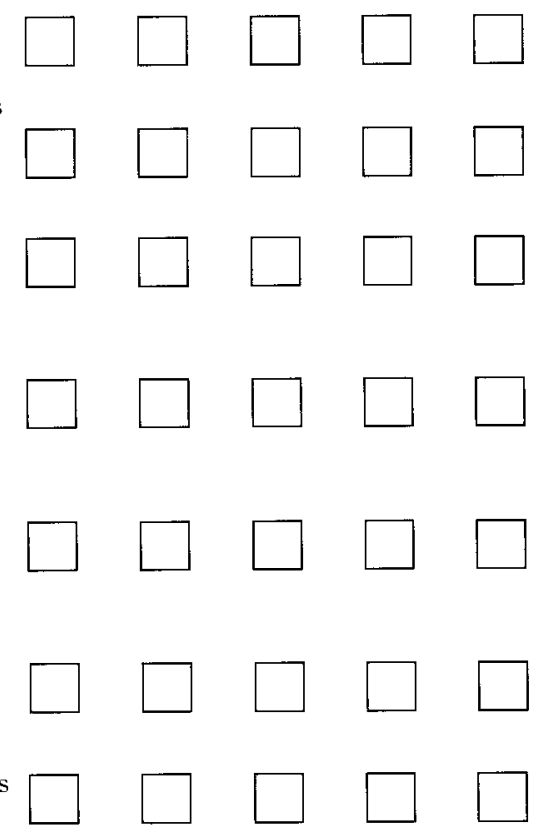

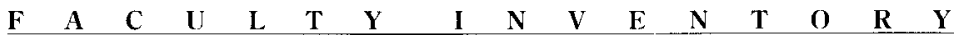

\section{Summary Responses}

After reviewing my responses to these seven areas and the items within them, the key area(s) I would like to work on is/are

As I look at my responses to this section, I would like to work on: 


\section{Appendix B}

Faculty Profile

1. What is your department?

2. What is (are) the subject area (areas) you teach?

3. How many years of experience do you have in teaching? (please check one category)
a.
$1-5$ years
b. $6-10$ years
c. $11-15$ years
d. more than 15 years

4. How many years of teaching experience do you have in these areas? Do not include years as a T.A. in graduate school.
a. ___ Middle or High School
c. Community College
b. ___ Research University
d. __ Business/Industry Trainer
e._4-Year college

5. How many hours do you teach (in classroom) per semester?(please check category)
a.
b. $6-8$
c. $9-12$
d. $12-15$
e. more than 15

6. What is your highest degree? (please check one category)
a.
B.S./B.A.
b. M.S./M.A.
c
Ph.D. or Ed.D.
d. Other (name of degree)

7. What is your gender? Male Female

8. Please check the developmental interventions your college offers to faculty. Check in front of the appropriate ones and then rate each session you attended with:

$\begin{array}{ccccc}\text { Excellent } & \text { very good } & \text { average } & \text { below average } & \text { poor } \\ 1 & 2 & 3 & 4 & 5\end{array}$

(for example:_x___ 3 _ College offers mentoring to faculty, mentor was average)

offered rating

offered rating

a. workshops on grading ___ f. mentors for new faculty

b. planning curricula ___ g. workshops on teaching

c. syllabus development ho workshops on advising

d. workshop on writing exams

i. workshops on technology

e. campus wide orientation

j. Others, name

9. Please indicate if your college provides you with the following.

Yes No Yes No

$\square-\begin{aligned} & \text { a. tour of facility } \\ & \text { b. telephone for you } \\ & \text { c. E-mail for you } \\ & \text { d. access to equipment }\end{aligned} \begin{aligned} & \text { f. office space for you } \\ & \text { g. secretarial help to you } \\ & \text { h. Audio-Visual equipment }\end{aligned}$
$\begin{aligned} & \text { i. Audio-Visual help for use } \\ & \text { j. Athers, name }\end{aligned}$


10. How many office hours do you have per week? ___ (state number of hours)

11. Do you normally tutor your students each week?
a. yes
b.
no
c. How many hours per week?

12. List your top 3 positive features, relative to instruction, which enhance your classroom teaching practice.

13. Please describe your top 3 concerns, which affect your ability to provide excellent instruction at your college. 